\title{
Polymorphous Public Law Litigation: The Forgotten History of Nineteenth Century Public Law Litigation
}

David Sloss

Santa Clara University School of Law, dlsloss@scu.edu

Follow this and additional works at: http://digitalcommons.law.scu.edu/facpubs

Part of the Law Commons

\section{Automated Citation}

David Sloss, Polymorphous Public Law Litigation: The Forgotten History of Nineteenth Century Public Law Litigation (2014), Available at: http://digitalcommons.law.scu.edu/facpubs/814

This Article is brought to you for free and open access by the Faculty Scholarship at Santa Clara Law Digital Commons. It has been accepted for inclusion in Faculty Publications by an authorized administrator of Santa Clara Law Digital Commons. For more information, please contact sculawlibrarian@gmail.com. 


\title{
Polymorphous Public Law Litigation: The Forgotten History of Nineteenth Century Public Law Litigation David Sloss
}

\begin{abstract}
Recent debates about popular constitutionalism and judicial supremacy have focused on the question of who interprets the Constitution. This article reframes the debate by asking what legal sources courts apply to protect individual rights from government infringement. Throughout the nineteenth century, federal courts applied a mix of international law, statutes and common law to protect fundamental rights and restrain government action. This article uncovers the forgotten history of nineteenth century public law litigation.
\end{abstract}

Professors Post and Siegel have advocated "policentric constitutional interpretation," wherein the Supreme Court shares authority for constitutional interpretation with other actors. By analogy, this article introduces the concept of "polymorphous public law litigation." Under the polymorphous model, instead of fixating on constitutional law as the dominant public law discourse, courts apply international law, statutes, and common law - and occasionally constitutional law - to decide public law controversies. The article demonstrates that nineteenth century federal courts applied a polymorphous model of public law litigation.

During the twentieth century, the polymorphous model was supplanted by a constitutionalized model of public law litigation, wherein courts rely primarily on constitutional law to decide public law cases. The process of constitutionalization exacerbated the tension between judicial review and popular sovereignty. When the Supreme Court applies constitutional law to decide a case, the Court does not merely decide the case; it also creates or modifies a legal rule that is not subject to revision by legislative majorities. In contrast, when the Court applies other types of law, Congress or state legislatures retain the power to modify the controlling legal rule. Hence, revival of a polymorphous model would help mitigate the tension between judicial review and popular sovereignty. 


\section{Contents}

Introduction 3

I. Conceptual Framework $\quad 8$

A. What is Public Law Litigation? 8

B. Judicial Review and Popular Sovereignty 9

C. Constitutionalization and Judicial Supremacy 13

II. An Empirical Analysis of Constitutionalization 14

A. Creating the Database 15

B. Methodology and Research Design 17

C. The Transition from Private Law to Public Law 20

D. The Constitutionalization of American Public Law 22

E. The Decline of the Polymorphous Model 28

F. Tentative Explanations for Constitutionalization 32

III. The Forgotten History of $19^{\text {th }}$ Century Public Law Litigation 34

A. Nineteenth Century International Law Claims 35

B. Land Claims in Louisiana and Florida 37

C. Chinese Habeas Litigation 45

D. Summary 53

IV. Reviving the Polymorphous Model of Public Law Litigation 54

A. International Human Rights Treaties as a Partial Substitute 55 for Constitutional Law

B. Three Illustrative Examples 58

C. Objections to the Polymorphous Model 62

Conclusion $\quad 66$

$\begin{array}{ll}\text { Appendix } & 68\end{array}$ 


\section{Polymorphous Public Law Litigation}

David Sloss, Draft, January 2014

\section{INTRODUCTION}

Larry Kramer and Mark Tushnet have sparked a vigorous scholarly debate about the merits of judicial supremacy. ${ }^{1}$ To date, that debate has focused primarily on the question of who interprets the Constitution. ${ }^{2}$ Is the Supreme Court "the ultimate expositor of the constitutional text,"3 as the Court claims? To what extent do Congress, the President, and "the people themselves" share the power to interpret and enforce the Constitution?

This article reframes the debate about judicial supremacy by raising a different question: what legal sources do courts apply to protect individual rights from government infringement? In the modern era we respond, almost reflexively, that courts apply the Constitution for this purpose. However, nineteenth century federal courts relied primarily on other sources of law, and only occasionally on constitutional law, to protect individual rights from government infringement. This article recovers the forgotten history of nineteenth century public law litigation. In that era, federal courts routinely applied a mix of international law, statutes and common law to protect fundamental rights and restrain government action.

How does the history relate to current debates about judicial supremacy? To answer that question, let us begin with a definition and some data. This article defines the term "public law cases" to comprise litigated cases involving a dispute between a private party and a government actor in which the private party alleges that the government committed, or threatened to commit, a violation of some established legal norm. ${ }^{4}$ Between 1801 and 1864, the Supreme Court applied international law in about $42 \%$ of the public law cases decided on the merits. During that period, the Court applied constitutional law in only about $13 \%$ of the public law cases decided on the merits. In contrast, between 1954 and 2005, the Court applied international law in only about $3 \%$ of the public law cases decided on the merits, while it applied constitutional law in about $64 \%$ of the public law cases decided on the merits. ${ }^{5}$ In short, the discourse of public law has changed from an international law discourse to a constitutional law discourse. The

\footnotetext{
1 See Larry D. Kramer, The People Themselves: Popular Constitutionalism and Judicial REVIEW (2004); MARK TUSHNET, TAKING THE CONSTITUTION AWAY FROM THE COURTS (1999).

${ }^{2}$ The literature is vast. For an excellent introduction to the debate, see the symposium in Volume 92 of the CALIFORNIA LAW REVIEW, including articles by Larry Kramer, Erwin Chemerinsky, Robert Post \& Reva Siegel, and Frederick Schauer. See also Larry Alexander \& Lawrence B. Solum, Book Review: Popular? Constitutionalism?, 118 HARV. L. REV. 1594 (2005).

${ }^{3}$ United States v. Morrison, 529 U.S. 598, 616 n.7 (2000).

4 The proper definition of "public law cases" is contested. See infra notes 27-32 and accompanying text.

${ }^{5}$ The data in this paragraph is drawn from an original database created by the author. Detailed information about the database and data analysis is presented in Part Two.
} 


\section{Polymorphous Public Law Litigation}

"constitutionalization" of American public law is the process wherein constitutional law displaced other sources of law as the dominant public law discourse in federal courts.

There is a deep tension between constitutionalization and the democratic commitment to popular sovereignty because constitutionalization transferred lawmaking authority from legislatures to federal courts. When the Supreme Court applies a statute or international legal rule to decide a case, the Court exercises final decision-making authority in that case, but Congress retains the power to modify the controlling domestic rule if Congress dislikes the Court's decision. ${ }^{6}$ In contrast, when the Court applies constitutional law to decide a case, it does not merely decide the case; it also creates or modifies a controlling legal rule that is not subject to revision by a legislative majority. Hence, the process of constitutionalization transferred lawmaking authority from legislative bodies to federal courts by generating a legal discourse in which courts decide public law cases by applying legal rules that are not subject to revision by ordinary legislation.

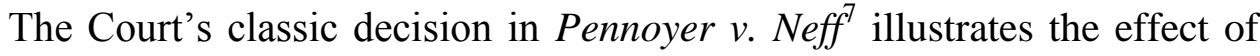
constitutionalization. Pennoyer involved a default judgment issued by an Oregon state court. Neff, the losing defendant in state court, sued Pennoyer in federal court to challenge the validity of the default judgment, claiming he "was a nonresident of the State ... [who] was not personally served with process, and did not appear therein." 8 The state court plaintiff served Neff by publication in a newspaper - a service method authorized by statute in Oregon. Despite express statutory authorization for service by publication, the Supreme Court held that the "judgment recovered in the State court of Oregon against the plaintiff herein . . . was without any validity.",

The Court rested its decision on "two well-established principles of public law." 10 First, "that every State possesses exclusive jurisdiction and sovereignty over persons and property within its territory." And second, "that no State can exercise direct jurisdiction and authority over persons or property without its territory." 11 The Court cited two international law treatises as authority - Story's

\footnotetext{
${ }^{6}$ Congress cannot unilaterally modify the international legal meaning of a rule of international law. However, Congress can enact legislation to control the domestic legal application of international law. See Restatement of the Law ThiRd, The Foreign Relations LaW of the UNITED STATES § 115(1)(a) [hereinafter, RESTATEMENT THIRD].

${ }^{7} 95$ U.S. 714 (1878).

${ }^{8}$ Id. at $719-20$.

${ }^{9} \mathrm{Id}$. at 734 .

${ }^{10} I d$. at 722 .

${ }^{11} \mathrm{Id}$.
} 


\section{Polymorphous Public Law Litigation}

David Sloss, Draft, January 2014

treatise on Conflict of Laws, and Wheaton's treatise on International Law. ${ }^{12}$ The Court also stated: "The international law . . . as it existed among the States in 1790, was that a judgment rendered in one State, assuming to bind the person of a citizen of another, was void within the foreign State, when the defendant had not been served with process or voluntarily made defence." ${ }^{\prime 3}$ In short, the Court held that the state court judgment was void because it conflicted with principles of international law.

It remains unclear why the Court thought it could apply international law to invalidate a state court judgment. One view is that the Court decided Pennoyer on state law grounds, using international law to interpret Oregon's personal jurisdiction statute. ${ }^{14}$ An alternative view is that the Court applied international law as federal common law. ${ }^{15}$ Regardless, the Court did not apply federal constitutional law to nullify the state court judgment. ${ }^{16}$ If one construes Pennoyer as a decision interpreting state law, then the Oregon legislature could have modified the jurisdictional rule. If one construes Pennoyer as an application of

\footnotetext{
${ }^{12} I d$.

${ }^{13}$ Id. at 730 (quoting D'Arcy v. Ketchum, 52 U.S. 165, 176 (1851)).

${ }^{14}$ Two sentences in Justice Field's opinion support this interpretation. See Pennoyer, 95 U.S. at 720. However, the opinion fills more than fifteen pages in U.S. Reports. The main thrust of the opinion strongly implies, without expressly holding, that a state jurisdictional statute inconsistent with "principles of public law" would be invalid. The conclusion that a state statute is invalid could not be based solely on statutory interpretation.

${ }^{15}$ Scholars have argued that nineteenth century federal courts applied customary international law as general common law, not federal common law. See Curtis A. Bradley \& Jack L. Goldsmith, Customary International Law as Federal Law: A Critique of the Modern Position, 110 HARV. L. REV. 815 (1997). Under the system derived from Swift v. Tyson, 41 U.S. 1 (1842), courts could not apply general common law to invalidate a state statute. As indicated above, Justice Field strongly implied that a state statute purporting to authorize jurisdiction in excess of territorial limits derived from international law would be invalid. Hence, Justice Field may have conceived of those territorial limits as something like federal common law, which does preempt conflicting state law.

The Court has a long tradition of applying customary international law as federal common law to resolve disputes between states. See Hinderlider v. La Plata River \& Cherry Creek Ditch Co., 304 U.S. 92 (1938); Michael D. Ramsey, Customary International Law in the Supreme Court, 1901-1945, in INTERNATIONAL LAW IN THE U.S. SUPREME COURT: CONTINUITY AND CHANGE 225, 229-31, 247-49 (Sloss, Ramsey \& Dodge eds. 2011) [hereinafter, CONTINUITY AND CHANGe]. In Pennoyer, Justice Field conceived of the central issue as a jurisdictional dispute between Oregon (Pennoyer's home state) and California (Neff's home state). Thus, insofar as Pennoyer suggests that state jurisdictional rules contravening territorial limits derived from international law would be invalid, Justice Field was arguably applying customary international law as federal common law to resolve a jurisdictional dispute between Oregon and California.

16 The Court's opinion mentions the Fourteenth Amendment Due Process Clause. See Pennoyer, 95 U.S. at 733. However, the Court did not base its holding on the Fourteenth Amendment because the state court judgment at issue in Pennoyer was rendered in February 1866, see id. at 716, and the Fourteenth Amendment was not ratified until 1868.
} 


\section{Polymorphous Public Law Litigation}

David Sloss, Draft, January 2014

federal common law, Congress could have modified the Pennoyer rule. ${ }^{17}$ Regardless, some legislative body retained the power to authorize state courts to exercise jurisdiction in contravention of Pennoyer's territorial rule.

Later Supreme Court decisions transformed the Pennoyer rule from a principle of international law to a federal constitutional rule. In short, the Court constitutionalized the Pennoyer rule by linking it to the Fourteenth Amendment Due Process Clause. ${ }^{18}$ The transformation of Pennoyer's territoriality principle from an international rule to a constitutional rule illustrates two general points about constitutionalization. ${ }^{19}$ First, constitutionalization has produced numerous judge-made constitutional rules that have little basis in the Constitution's text. ${ }^{20}$ The text of the Due Process Clause says nothing about territorial limits on state court jurisdiction. Similarly, much of modern constitutional law consists of judgemade rules that are at best loosely related to the actual constitutional text.

Second, the process of constitutionalization transferred lawmaking power from state and federal legislatures to federal courts. In 1878, when the Court decided Pennoyer, either Congress, or state legislatures, or both retained the power to authorize state courts to exercise jurisdiction over non-resident defendants in contravention of Pennoyer's territoriality rule. By 1900, though, neither Congress nor state legislatures had the power to legislate contrary to the Pennoyer rule because the Court had incorporated that rule into the Due Process Clause. $^{21}$ Thus, constitutionalization transferred lawmaking power from democratically elected legislatures to unelected federal judges.

Against this background, let us reconsider the question of judicial supremacy. Larry Kramer defines judicial supremacy as "the notion that judges

\footnotetext{
${ }^{17}$ Insofar as federal courts have the power to create federal common law, Congress must be able to modify judge-made rules by exercising its Article I powers. The contrary view - that federal courts can create common law outside the scope of Congress' Article I powers - would be inconsistent with Article I, which states: "All legislative Powers herein granted shall be vested in a Congress of the United States." U.S. Const. art. I, § 1.

${ }^{18}$ See, e.g., Scott v. McNeal, 154 U.S. 34, 46 (1894); see also Thomas H. Lee and David L. Sloss, International Law as an Interpretive tool in the Supreme Court, 1861-1900, in CONTINUITY AND CHANGE, supra note 15, at 124, 151-52.

${ }^{19}$ Pennoyer is not a "public law" case as defined in this article. See infra notes 27-32 and accompanying text. Even so, Pennoyer helps illustrate the impact of constitutionalization because the Court's subsequent personal jurisdiction doctrine transformed Pennoyer's international rule into a constitutional rule.

${ }^{20}$ See, e.g., LAURENCE H. TRIBE, THE InVISIBLE CONSTITUTION 25 (2008).

${ }^{21}$ The territorial jurisdiction of federal courts in federal question cases is governed by the Fifth Amendment Due Process Clause. Congress may authorize federal courts to exercise jurisdiction beyond the Fourteenth Amendment limits that apply to state courts, but Congress may not authorize jurisdiction beyond limits set by the Fifth Amendment. See generally FrIEDMAN, LANDERS \& COLlins, THE LAW OF CiVIL PROCEDURE: CASES AND MATERIALS 126 (2002).
} 


\section{Polymorphous Public Law Litigation}

have the last word when it comes to constitutional interpretation and that their decisions determine the meaning of the Constitution for everyone." 22 Critics contend that judicial supremacy is inconsistent with popular sovereignty. ${ }^{23}$ Advocates of judicial supremacy acknowledge the tension between judicial supremacy and popular sovereignty, but insist that supremacy is necessary to promote other important values. ${ }^{24}$

The history of nineteenth century public law litigation, as elucidated in this article, illustrates one way to mitigate the tension between judicial supremacy and popular sovereignty. Between 1801 and 1864, the Supreme Court resolved almost $90 \%$ of its public law cases by applying legal norms other than constitutional norms. Imagine that modern legal discourse was transformed so that litigants framed most of their public law claims as statutory, common law, or international law claims, and federal courts decided most public law cases without applying constitutional law. In those circumstances, the political salience of judicial supremacy would be greatly diminished. Judicial supremacy would remain the rule for the small subset of public law cases where courts applied constitutional law, but the revised legal discourse would mitigate the tension between judicial supremacy and popular sovereignty. Federal courts would decide the vast majority of public law cases by applying legal rules that could be revised by majority vote in a democratically elected legislature.

Professors Post and Siegel have advocated "policentric constitutional interpretation," wherein authority for constitutional interpretation is divided among the Supreme Court, Congress, and other actors. ${ }^{25}$ By analogy, this article introduces the concept of "polymorphous public law litigation." Under the polymorphous model, instead of fixating on constitutional law as the dominant public law discourse, lawyers and judges invoke and apply treaties, customary international law, statutes, common law — and occasionally constitutional law — to litigate and decide public law controversies. ${ }^{26}$ The article demonstrates that nineteenth century federal courts actually applied a polymorphous model of public law litigation.

\footnotetext{
${ }^{22}$ KRAMER, supra note 1 , at 125.

${ }^{23}$ See generally TUSHNET, supra note 1; KRAMER, supra note 1.

${ }^{24}$ See, e.g., Erwin Chemerinsky, In Defense of Judicial Review: A Reply to Professor Kramer, 92 CAL L. REV. 1013 (2004) (emphasizing "[t]he rights of minorities . . criminal defendants, public benefits recipients, and others"); Alexander \& Solum, supra note 2 (emphasizing "rule of law" values and the need for settlement).

${ }^{25}$ See Robert C. Post and Reva B. Siegel, Legislative Constitutionalism and Section Five Power: Policentric Interpretation of the Family and Medical Leave Act, 112 YALE L. J. 1943 (2003).

${ }^{26}$ Insofar as the polymorphous model would reduce judicial reliance on constitutional law, it is similar to Professor Schauer's concept of the "modest Constitution." See Frederick Schauer, Judicial Supremacy and the Modest Constitution, 92 CAL. L. REV. 1045 (2004).
} 


\section{Polymorphous Public Law Litigation}

David Sloss, Draft, January 2014

Part One sets forth a conceptual framework for the ensuing discussion by analyzing the relationship among five key concepts: public law litigation, judicial review, judicial supremacy, constitutionalization, and popular sovereignty. Part Two presents an empirical analysis of constitutionalization, drawing on an original database created by the author. Part Three presents two case studies to illustrate the application of a polymorphous model of public law litigation by nineteenth century federal courts. Part Four addresses the contemporary feasibility and desirability of reversing the process of constitutionalization and reviving a polymorphous model of public law litigation.

\section{I}

\section{Conceptual Framework}

Part One is divided into three sections. The first section discusses the concept of public law litigation. The next section analyzes the relationship between judicial review and popular sovereignty. The final section addresses the relationship between constitutionalization and judicial supremacy.

\section{A. What is Public Law Litigation?}

There is no agreed definition of the term "public law litigation." "Private law litigation" is easier to define. In private law cases, courts are "called upon to resolve private disputes between private individuals according to the principles of private law." "27 One could define "public law cases" to encompass everything other than private law cases, but that definition is overbroad. ${ }^{28}$ Professor Chayes says that "public law litigation" includes cases in which courts "are asked to deal with grievances over the administration of some public or quasi-public program and to vindicate the public policies embodied in the governing statutes or constitutional provisions." ${ }^{29}$ This definition is excessively narrow. It excludes cases in which courts are asked to vindicate the public policies embodied in treaties or customary international law. Those cases comprised a substantial portion of the Supreme Court's public law caseload before the Civil War.

Professors Goldsmith and Levinson define "public law" to include "constitutional and international law - legal regimes that both constitute and govern the behavior of states and state actors." 30 Their analysis provides

\footnotetext{
${ }^{27}$ Abram Chayes, Foreword: Public Law Litigation and the Burger Court, 96 HARV. L. REV. 4, 4 (1983)

${ }^{28}$ Three categories of cases are neither "private law" nor "public law" cases, as those terms are used in this article. See infra note 59.

${ }^{29}$ Chayes, supra note 27, at 4.

${ }^{30}$ Jack Goldsmith and Daryl Levinson, Law for States: International Law, Constitutional Law, Public Law, 122 HaRV. L. ReV. 1791, 1795 (2009).
} 


\section{Polymorphous Public Law Litigation}

important insights about the similarities between international law and constitutional law. ${ }^{31}$ Moreover, their definition is helpful because it focuses on the use of law to govern the behavior of state actors. However, their analysis obscures the fact that courts also apply statutory and common law to regulate state actors.

This article adopts a functional approach. In private law cases, courts adjudicate disputes between private parties. In public law cases, private actors ask courts to apply their judicial power to regulate the conduct of government actors. Accordingly, this article defines "public law cases" to comprise litigated cases involving a dispute between a private party and a government actor in which the private party alleges that the government actor committed, or threatened to commit, a violation of some established legal norm. ${ }^{32}$ The legal norm might be expressed in constitutional law, statutory law, international law, or common law. The defining feature of public law litigation is not the source of the norm; it is the fact that a private party seeks judicial assistance in regulating the conduct of government actors.

\section{B. Judicial Review and Popular Sovereignty}

Courts engage in "judicial review," as defined herein, ${ }^{33}$ when they assess the legality of federal, state, or local government action, including action by legislatures, courts, and executive or administrative agencies or officers. ${ }^{34}$ Judicial review typically involves some element of judicial lawmaking. Courts are required to apply the law. However, the line between "applying law" and "making law" is notoriously fuzzy. In most cases, appellate judges "make" law in the very process of "applying" law. When judges apply specific, narrowly drawn legal rules the leeway for judicial lawmaking is more limited. When they apply broad, vaguely worded legal rules the leeway for judicial lawmaking is greater. Appellate judges often apply broad, vaguely worded legal rules because that is an essential part of their job. Therefore, appellate judges cannot perform the vital task of judicial review without engaging in some judicial lawmaking.

\footnotetext{
${ }^{31}$ See id.

${ }^{32}$ Aside from the inclusion of international law claims, the difference between Prof. Chayes' definition and mine is largely semantic. By focusing on the effort to "vindicate public policies," Chayes tacitly adopts the government's perspective. By focusing on violations of legal norms by government officers, my definition purposefully adopts the private party's perspective. Regardless, the class of cases covered by the two formulations is similar.

${ }^{33}$ Judicial review is not the same as public law litigation. Courts sometimes perform judicial review in private law cases. See infra note 69 and accompanying text.

${ }^{34}$ The term "judicial review" is sometimes defined more narrowly to include only cases where courts evaluate the constitutional validity of legislation. That narrow definition would exclude most nineteenth century public law litigation, because nineteenth century lawyers challenged executive and administrative action much more frequently than they challenged legislative action. See infra Part II.E. This article adopts a broad definition to facilitate comparison between nineteenth century judicial review and modern judicial review.
} 


\section{Polymorphous Public Law Litigation}

"Popular sovereignty" means that people are governed by laws of their own creation. The people can make law directly, by referendum, or indirectly, by electing representatives who make laws on their behalf. ${ }^{35}$ Given the inevitability of judicial lawmaking, there is inherent tension between judicial review and popular sovereignty, because judge-made law is not made by "the people.",36 Other things being equal, tension between judicial review and popular sovereignty is mitigated when the outcome of judicial lawmaking is subject to modification by a popularly elected legislature. In contrast, tension between judicial review and popular sovereignty is exacerbated when the product of judicial lawmaking is not subject to revision by an elected legislature.

This observation provides a basis for assessing the impact on popular sovereignty of different forms of judicial review. If the Supreme Court applies federal constitutional law as a rule of decision, the Court does not merely decide the case. It also creates or modifies the controlling rule, yielding a constitutional rule that is not subject to revision by legislative majorities in Congress or state legislatures. ${ }^{37}$ Thus, in a system characterized by judicial supremacy, judicial review based on federal constitutional law tends to exacerbate the tension between judicial review and popular sovereignty because judge-made constitutional law cannot be modified by a popularly elected legislature. ${ }^{38}$

In contrast, if the Supreme Court applies a federal statute to decide a case, the Court has final decision-making authority in the case, but Congress retains the power to amend the statute. If the Court applies a treaty to decide a case, Congress cannot rewrite the treaty, but Congress can enact a later-in-time statute that supersedes the treaty for purposes of domestic law. ${ }^{39}$ Similarly, when the Court applies customary international law to decide a case, Congress cannot rewrite the international legal rule, but some domestic legislature has the power to

\footnotetext{
${ }^{35}$ Citizens also shape lawmaking in less formal ways, but elections and referenda are the primary formal mechanisms for citizens to influence the lawmaking process.

${ }^{36}$ Various mechanisms empower citizens to exercise popular control over judges. Federal judges must be confirmed by the peoples' representatives in the Senate. Many states have some form of judicial elections. Regardless, the average citizen has less power to control judicial lawmaking than he or she has to influence legislative lawmaking.

${ }^{37}$ Some federal constitutional rules are subordinated to the will of Congress. For example, Article I, section 10 lists actions that states shall not undertake "without the Consent of Congress." U.S. Const., art. I, § 10. Regardless, the vast majority of federal constitutional rules are not subject to revision by legislative majorities.

${ }^{38}$ Some forms of constitutional judicial review are democracy-enhancing. See, e.g., Pamela S. Karlan, The Supreme Court 2011 Term, Foreword: Democracy and Disdain, 126 HARV. L. REV. 1, 4 (2012). However, constitutional judicial review as practiced by the Rehnquist and Roberts Courts tends to exacerbate the tension between judicial review and popular sovereignty. See generally id. at 27-71.

${ }^{39}$ See RESTATEMENT THIRD, supra note $6, \S 115(1)(a)$.
} 


\section{Polymorphous Public Law Litigation}

enact legislation to displace the international rule for purposes of domestic law. ${ }^{40}$ Thus, judicial review based on statutes, treaties, or customary international law mitigates the tension between judicial review and popular sovereignty because popularly elected legislatures retain the power to modify the controlling domestic rules if they dislike the outcome of the Court's judicial lawmaking. ${ }^{41}$

Scholars who criticize the democracy deficit of international law typically focus on the initial lawmaking process, not the power of elected legislatures to modify the results of judicial lawmaking. Under this view, one could say that the Constitution is "democratic" because the original Constitution was ratified by state conventions whose members were popularly elected. ${ }^{42}$ Moreover, much international law is "undemocratic" because it is not made by popularly elected legislatures. ${ }^{43}$

Although it is reasonable to compare the democratic legitimacy of international and constitutional law by reference to the initial lawmaking process, the preceding argument is misleading. Virtually all modern federal constitutional law is constitutional common law; it is the product of a judicial lawmaking process that is largely untethered from the constitutional text. ${ }^{44}$ Constitutional common law has never been approved by majority vote in any legislature. Therefore, the process for making federal constitutional law is in tension with the ideal of popular sovereignty because most federal constitutional law is made by unelected judges, not popularly elected legislatures. ${ }^{45}$

Concerns about the democracy deficit of international law focus on the process for creating law on the international plane. Broadly speaking, those

\footnotetext{
${ }^{40}$ If a rule of customary international law falls within the scope of Congress' legislative authority, Congress can enact federal legislation to modify the controlling domestic rule. See id. If the international rule is beyond the scope of Congress' legislative authority, then it presumably falls within the scope of state legislative authority, and state legislatures can modify the controlling domestic rule.

${ }^{41}$ The rule that Congress has the power to override customary international law was well settled before the Civil War. See David L. Sloss, Michael D. Ramsey, and William S. Dodge, International Law in the Supreme Court to 1860, at 32-34, in CONTINUITY AND CHANGE, supra note 15. The rule that Congress has the power to override treaties did not become firmly established until the 1870s or 1880s. See id. at 18-19; Duncan B. Hollis, Treaties in the Supreme Court, 1861-1900, at 73-74, in CONTINUITY AND CHANGE, supra note 15.

${ }^{42}$ See Jack N. Rakove, Original Meanings: Politics and IDEAS in the Making of the CONSTITUTION 113-28 (1996) (discussing state ratifying conventions).

${ }^{43}$ See, e.g., John O. McGinnis \& Ilya Somin, Should International Law Be Part of Our Law?, 59 STAN. L. REV. 1175 (2007).

${ }^{44}$ See David A. Strauss, Common Law Constitutional Interpretation, 63 U. CHI. L. REv. 877 (1996).

${ }^{45}$ The tension remains, even assuming that other features of our constitutional system ensure that the Court's constitutional decisions do not stray too far from current majoritarian preferences.
} 


\section{Polymorphous Public Law Litigation}

concerns are well-founded. ${ }^{46}$ However, in evaluating whether international-lawbased judicial review is consistent with principles of popular sovereignty, the more salient question is how a particular rule of international law is incorporated into domestic law. If an international norm is incorporated into domestic law by majority vote in an elected legislature, application of that norm by domestic courts is generally consistent with principles of popular sovereignty. Here, one must distinguish between treaties, congressional-executive agreements, sole executive agreements, and customary international law.

An Article II treaty becomes law in the United States only after a supermajority vote in the Senate and Presidential ratification. ${ }^{47}$ Similarly, congressional-executive agreements require a majority vote in both Houses of Congress. ${ }^{48}$ Thus, judicial application of Article II treaties and congressionalexecutive agreements is broadly consistent with popular sovereignty ${ }^{49}$ because those legal norms are incorporated into U.S. law by a majoritarian, democratic process. $^{50}$ In contrast, courts sometimes apply sole executive agreements ${ }^{51}$ or rules of customary international law $^{52}$ that have not been approved by any domestic legislature. Judicial review of government conduct by reference to sole executive agreements, or unincorporated customary international law, ${ }^{53}$ creates greater tension with popular sovereignty because courts are applying legal norms that have not been approved by a popularly elected legislature.

\footnotetext{
${ }^{46}$ See McGinnis \& Somin, supra note 43.

${ }^{47}$ See U.S. Const. art. II, $\S 2$.

${ }^{48}$ See Restatement (THIRD), supra note $6, \S 303$, cmts. a, e.

${ }^{49}$ There are two types of congressional-executive agreements: "ex ante" and "ex post." Congress approves "ex post" agreements after the text has been negotiated. The democratic pedigree of such agreements is unimpeachable. The Executive Branch negotiates "ex ante" agreements on the basis of prior statutory authorization. The Executive Branch sometimes claims prior authorization based on statutory language that is vague, outdated, or both. Accordingly, scholars have challenged the democratic pedigree of "ex ante" agreements, noting that the Executive Branch sometimes claims statutory authorization for an agreement that is largely the product of lawmaking by unelected executive officials. See Oona A. Hathaway, Presidential Power Over International Law: Restoring the Balance, 119 YALE L. J. 140, 155-67 (2009).

${ }^{50}$ Many international agreements include broad, vaguely worded provisions that leave ample leeway for judicial lawmaking. Such agreements are similar to the Constitution in this respect. However, in contrast to the Constitution, judicial lawmaking based on such international agreements is subject to revision by elected legislatures.

${ }^{51}$ Sole executive agreements are binding international agreements concluded by the President without congressional approval on the basis of his Article II authority. See RESTATEMENT (THIRD), supra note $6, \S 303$, cmts. g, h.

${ }^{52}$ See, e.g., Manoharan v. Rajapaksa, 711 F.3d 178 (D.C. Cir. 2013) (applying the customary international law doctrine of head-of-state immunity to justify dismissal of a claim against Sri Lanka's head of state).

${ }^{53}$ Judicial application of customary international law that has been incorporated into a federal statute is generally consistent with democratic principles. See infra notes 315-21 and accompanying text.
} 


\section{Polymorphous Public Law Litigation}

In sum, concerns about the democratic legitimacy of international law are well-founded, insofar as one focuses on the lawmaking process on the international plane. However, judicial application of federal constitutional law exacerbates the tension between judicial review and popular sovereignty more than any other form of judicial review. Most modern constitutional law is the product of a lawmaking process controlled by unelected federal judges. Moreover, judicial lawmaking based on federal constitutional law — unlike judicial lawmaking based on treaties, executive agreements, or customary international law - yields outcomes that are not subject to revision by a popularly elected legislature.

\section{Constitutionalization and Judicial Supremacy}

Constitutionalization is the process whereby constitutional law displaced other sources of law as the dominant public law discourse in federal courts. As the public law litigation system has become increasingly constitutionalized, federal courts have increasingly relied on constitutional law as the primary source of law to resolve public law controversies. ${ }^{54}$

The term "judicial supremacy" describes a system in which "judges have the last word when it comes to constitutional interpretation and . . their decisions determine the meaning of the Constitution for everyone." 55 Constitutionalization and judicial supremacy are not necessarily connected. In theory, the U.S. could have a system of judicial supremacy without constitutionalization. In that case, courts would determine the meaning of the Constitution, but they would apply the Constitution only rarely. Alternatively, we could have constitutionalization without judicial supremacy. In that case, courts would apply the Constitution to resolve most public law controversies presented for judicial decision, but other government actors would not be bound by judicial interpretations of the Constitution (except that parties would be bound by decisions in cases where they are parties).

Professor Kramer has shown that judicial supremacy did not become an entrenched feature of the U.S. constitutional system until the period between the Supreme Court's 1958 decision in Cooper v. Aaron ${ }^{56}$ and Edwin Meese's 1986 speech advocating a departmental theory of constitutional interpretation. ${ }^{57}$ As shown in Figure Three below, this is roughly the same period when constitutional law discourse became firmly established as the dominant public law discourse in the United States.

${ }^{54}$ See infra Part II.D.

${ }^{55}$ KRAMER, supra note 1 , at 125 .

56358 U.S. 1 (1958).

${ }^{57}$ See KRAMER, supra note 1 , at 220-21. 


\section{Polymorphous Public Law Litigation}

If the U.S. legal system had developed constitutionalization without judicial supremacy, then judicial review would not threaten popular sovereignty because popularly elected legislatures could reject the Supreme Court's constitutional rulings. Similarly, if the U.S. had developed judicial supremacy without constitutionalization, popular sovereignty would not be threatened because most judicial review would be based on statutes, international law, and/or common law. In that case, democratically elected legislatures would retain the power to modify the governing legal rules. In fact, though, our system of public law litigation has evolved in a way that combines constitutionalization with judicial supremacy. That combination creates significant tension between judicial review and the principle of popular sovereignty.

Advocates of popular constitutionalism seek to resolve that tension by rejecting judicial supremacy. Advocates of judicial supremacy contend that the popular constitutionalist cure is worse than the disease. ${ }^{58}$ However, even the most ardent proponents of judicial supremacy would presumably admit that the ideal of popular sovereignty is a core ideal of our democratic system, and that our current, constitutionalized system of public law litigation creates significant tension between judicial review and popular sovereignty.

The preceding analysis offers a potential solution to this dilemma. If we could partially reverse the process of constitutionalization, and revive the nineteenth century model of polymorphous public law litigation, then we could preserve the benefits of judicial review and mitigate the tension between judicial supremacy and popular sovereignty. I return to this idea in Part Four below. Parts Two and Three demonstrate that federal courts actually applied a polymorphous model of public law litigation throughout the nineteenth century.

\section{II}

\section{An Empirical Analysis of Constitutionalization}

Part Two presents an empirical analysis of constitutionalization. The first section provides an overview of the databases used for the analysis. The second section discusses methodology and research design. The third section documents the Supreme Court's transition from a private law to a public law focus. The next section shows that, within the class of public law cases, constitutional law displaced other sources of law as the dominant public law discourse in the Supreme Court. The final section offers some tentative, possible explanations for the process of constitutionalization.

\footnotetext{
${ }^{58}$ See, e.g., Alexander and Solum, supra note 2; Chemerinsky, supra note 24.
} 


\section{Polymorphous Public Law Litigation}

David Sloss, Draft, January 2014

\section{A. Creating the Database}

Creation of the database proceeded in two phases. In phase one, I segregated public law cases from other cases so that phase two analysis could focus exclusively on public law cases. Phase one applied a simple, quick, objective method to review approximately 27,000 Supreme Court cases and identify the public law cases within the larger universe.

In phase one, classification was based strictly on the identity of the parties. If all parties to the litigation are private actors, the case is classified as PP (private law). If a private actor is adverse to a government actor, the case is classified as PG (public law). ${ }^{59}$ The PG classification provided an excellent proxy for identifying true "public law cases," as defined above. Phase two analysis confirmed that approximately ninety-eight percent of the cases correctly classified as PG in phase one are "public law cases," as defined herein. ${ }^{60}$

I divided Supreme Court history from 1801 to 2005 into eight periods. Period 1 is the Marshall Court (1801-35) and Period 2 is the Taney Court (183664). The transition between Periods 2 and 3 corresponds with the end of the Civil War and the appointment of Chief Justice Salmon Chase. Period 3 (1865-88) goes from the Civil War to the industrial revolution; it ends in 1888 when Melville Fuller replaced Morrison Waite as Chief Justice. Period 4 (1888-1910) covers

\footnotetext{
${ }^{59}$ The phase one database includes three types of cases that are neither PP nor PG. If one of the parties is a foreign state, the case is classified as FS. FS cases are not "public law" because they do not involve a dispute between a private party and a domestic government actor. Suits between domestic government actors, such as a suit between the United States and one of its constituent states, are classified as GG. GG cases do not qualify as "public law" because they do not involve a dispute between a private party and a government actor. Mixed party cases, in which a government actor and a private party are co-parties, are classified as MP.

Classification of MP cases is problematic. Some MP cases are similar to PG cases because the underlying dispute is between a private party and a government actor. However, most MP cases involve an underlying dispute between two private parties that was litigated before an administrative tribunal. When the tribunal's decision is appealed to a court, or the administrative agency sues to enforce the tribunal's decision, the agency becomes a co-party with one of the parties to the underlying dispute. Such cases are like PP cases because the underlying dispute is between private parties. Since phase one was designed to provide a quick, simple method for distinguishing between public and private law cases, I chose to exclude all MP cases from the class of public law cases.

${ }^{60}$ In phase two, I selected at random 1400 PG cases for detailed analysis. I eliminated 137 of those cases because the initial classification was incorrect. (They should have been classified as MP or PP. See Appendix, Table One.) I eliminated 24 other cases because there was insufficient information to perform the detailed phase two analysis. That left 1239 cases for phase two analysis. In 27 of those 1239 cases, there was no allegation of unlawful government conduct. The other 1212 cases satisfy the above definition of "public law cases" because the private party alleged that the government actor violated some established legal norm.
} 


\section{Polymorphous Public Law Litigation}

Melville Fuller's tenure as Chief Justice; it includes the beginning of the Lochner era.

Period 5 (1910-36) covers the remainder of the Lochner era; it ends with the final term before West Coast Hotel v. Parrish, ${ }^{61}$ which overruled Lochner v. New York. ${ }^{62}$ Period 6 (1936-54) begins with West Coast Hotel and ends with the last term before Brown v. Board of Education. ${ }^{63}$ Brown coincides with the beginning of the Warren Court. Period 7 (1954-72) covers the Warren Court and ends with the last term before Roe v. Wade. ${ }^{64}$ The transition from Period 7 to 8 is marked by the appointments of Chief Justice Warren Burger (1969) and Associate Justices Rehnquist and Powell (1972), which created a conservative majority for the first time since 1937. Period 8 (1973-2005) begins with Roe and ends with the final term of the Rehnquist Court. The lines dividing periods are necessarily somewhat arbitrary. However, there is no reason to believe that selection of different dividing lines would yield substantially different results.

Whereas phase one involved "quick and dirty" analysis of about 27,000 Supreme Court decisions, ${ }^{65}$ phase two entailed more detailed analysis of 1400 PG cases from periods $1,2,3,6,7$, and 8 . I excluded periods 4 and 5 from the phase two database because this project examines the contrast between nineteenth century public law litigation and modern public law litigation. A follow-on project will examine in greater detail the transition in periods 4 and 5 .

For phase two, I selected a random sample of PG cases from each of the periods identified above. ${ }^{66}$ Research assistants and I analyzed the Supreme Court decisions, the lower court decisions (when available), and the parties' arguments. We recorded information about the type of law invoked by lawyers, lower court judges, and Supreme Court Justices - including common law, state law, federal statutes, treaties, customary international law, and federal constitutional law. ${ }^{67} \mathrm{We}$

${ }^{61} 300$ U.S. 379 (1937).

${ }^{62} 198$ U.S. 45 (1905).

${ }^{63} 347$ U.S. 483 (1954).

${ }^{64} 410$ U.S. 113 (1973).

${ }^{65}$ In phase one, student research assistants reviewed every Supreme Court decision from John Marshall's first term as Chief Justice until William Rehnquist's last term. Students classified every case as PP, PG, FS, GG, or MP. See supra note 59. To facilitate timely completion, I instructed students to spend no more than five minutes per case, and to resolve doubts in favor of a PG classification. The latter instruction yielded an over-estimate of the number of PG cases in phase one; that was a deliberate attempt to ensure that no PG cases were excluded from the universe from which I drew a random sample in phase two. Subsequently, I did an error analysis to compensate for the initial over-estimate. See Appendix, Table One.

${ }^{66}$ Phase two analysis is based on a random sample of 360 PG cases from period 8, 240 PG cases from period 7, and $200 \mathrm{PG}$ cases each from periods 1,2,3, and 6 .

${ }^{67}$ For periods 6 to 8 , two students reviewed every sample case and entered information into an Excel file in accordance with my detailed instructions. Students compared their entries to each 


\section{Polymorphous Public Law Litigation}

documented the frequency with which lawyers and judges invoked and applied different types of law in different time periods. We also recorded a large volume of other information for every case in the phase two database. ${ }^{68}$ The phase two database enables one to derive a quantitative measurement of the extent to which constitutional law has displaced other sources of law as the dominant discourse in public law cases.

\section{B. Methodology and Research Design}

Part Two employs quantitative analysis, but presents the data in a way that is accessible to readers with no training in statistical methods. To make the analysis accessible, I present the data in graphic form, with very few numbers. The Appendix contains detailed tables supporting the information presented graphically in Part Two. The text and footnotes in Part Two identifies the findings that are statistically significant. Given the basic choice of a "soft empiricist" methodology, there are two potential objections to project design that merit a response: 1) the definition of "public law" excludes many cases that should be included; and 2) the focus on Supreme Court cases excludes a large body of public law litigation in state courts. I address these issues below.

1. The Definition of Public Law (Revisited): Courts often perform judicial review in private law cases. For example, in a dispute between private parties, where one party invokes a state statute to support its position, the opposing party may argue that the statute is unconstitutional, or that it is preempted by federal law. ${ }^{69}$ If the court rules on the validity of state law, it is engaging in judicial review. However, such cases are excluded from phase two analysis because they were classified as "PP" in phase one: a dispute between private parties. Thus, exclusion of PP cases from phase two excludes some cases involving judicial review.

Nevertheless, exclusion of PP cases from phase two analysis is justified. First, inclusion of PP cases in the universe from which a random sample was selected would have created serious problems. The Supreme Court's nineteenth century docket included more PP than PG cases, whereas the Court's twentieth

other's and referred disagreements to me. I reviewed the Excel files for consistency and accuracy. For periods 1 to 3, I reviewed the cases myself and entered data into Excel files. The nineteenth century jurisprudence is sufficiently unfamiliar to most law students that I could not rely on student research assistants to enter accurate information about nineteenth century cases.

68 The data for phases one and two is recorded in Excel files that are available upon request. The instructions provided to research assistants are also available upon request.

69 See, e.g., Aetna Health Inc. v. Davila, 542 U.S. 200 (2004) (in suit between private parties, Court held that ERISA preempted Texas Health Care Liability Act); Boy Scouts of America v. Dale, 530 U.S. 640 (2000) (in suit between private parties, Court held that New Jersey statute violated First Amendment). 


\section{Polymorphous Public Law Litigation}

David Sloss, Draft, January 2014

century docket included more PG than PP cases. ${ }^{70}$ The project was designed to compare nineteenth century public law litigation to modern public law litigation. If the random sample drew from a universe comprising all PP and PG cases, the sample would have been weighted more toward PP cases in the nineteenth century, and more toward PG cases in the twentieth century. Given the generic differences between private law and public law litigation, ${ }^{71}$ this would have produced an "apples to oranges" comparison, instead of an "apples to apples" comparison.

Moreover, the project was designed to test the hypothesis that the nineteenth century Supreme Court applied international law more frequently than it applied constitutional law. During the nineteenth century, the Court often applied international law to help resolve disputes between private parties. $^{72}$ Hence, if one drew a sample from a universe comprising all PP and PG cases, the PP cases would likely skew the results for the nineteenth century in favor of international law, because the nineteenth century Supreme Court probably applied international law more frequently than it applied constitutional law to resolve disputes between private parties. ${ }^{73}$ Therefore, PP cases are excluded from phase two to avoid skewing the results.

2. Public Law Litigation in State Courts: The author constructed the project database by reviewing U.S. Supreme Court decisions. Phase two analysis included review of state court and lower federal court decisions that were appealed to the Supreme Court. However, state court decisions that never reached the Supreme Court are excluded from both phase one and phase two databases. Exclusion of such decisions is potentially significant because state courts handle lots of public law litigation. In the nineteenth century, there was a rich tradition of public law litigation in state courts. ${ }^{74}$ It is questionable whether international law was ever the dominant public law discourse in state courts, even in the nineteenth century. ${ }^{75}$ Thus, the empirical evidence supports the claim that international law

\footnotetext{
${ }^{70}$ See infra Figure One, and Appendix, Table One.

${ }^{71}$ See supra notes 27-32 and accompanying text.

72 See generally CONTINUITY AND CHANGE, supra note 15. The book documents the Supreme Court's application of international law from the Founding to the present.

${ }^{73}$ I thank Professor Paul Stephan for identifying this issue during early discussions about project design.

74 See Jed Handelsman Shugerman, The People's Courts: Pursuing Judicial INDEPENDENCE IN AMERICA 123-43 (2012).

75 Figure Seven below shows that international law was never the dominant discourse in public law cases involving claims against state and local government actors. Most public law claims against federal government actors have traditionally been litigated in federal court, not state court. Since international law never featured prominently in public law claims against state and local government actors, one could reasonably infer that the international law discourse that prevailed in federal courts in the pre-Civil War era was not as prevalent in state courts during that period.
} 


\section{Polymorphous Public Law Litigation}

was the dominant public law discourse in federal courts before the Civil War, ${ }^{76}$ but it does not support any empirical claim about public law litigation in state courts in the nineteenth century.

Hence, one could argue that exclusion of state court cases presents a distorted picture of nineteenth century public law litigation. Nevertheless, that exclusion is justified. First, the project focuses on the constitutionalization of American public law. The U.S. Supreme Court's increasing reliance on federal constitutional law to resolve public law controversies is problematic because application of federal constitutional law exacerbates the tension between judicial review and popular sovereignty. In contrast, application of state constitutional law by state supreme courts is more consistent with principles of popular sovereignty. ${ }^{77}$ Therefore, application of state law by state courts is tangential to the concerns about the anti-democratic effects of constitutionalization that motivate this project.

Second, an attempt to collect systematic, quantitative data about public law litigation in fifty state supreme courts over two hundred years would face tremendous practical obstacles. Many state supreme court decisions are unpublished, especially in older cases. Quantitative analysis cannot readily account for unpublished decisions. Exclusion of unpublished decisions would introduce bias into the results, and it would be difficult to assess the magnitude or directionality of that bias. Apart from concerns about biased data, the volume of potentially relevant decisions is enormous. Hence, expansion of the project to encompass state supreme court decisions would not have been feasible in a reasonable time frame.

\footnotetext{
${ }^{76}$ One might object that the empirical evidence merely supports claims about the Supreme Court, not lower federal courts. However, unlike the modern Court, the nineteenth century Supreme Court had very little control over the types of cases it received from the lower federal courts. See Carolyn Shapiro, A "Progressive Contraction of Jurisdiction": The Making of the Modern Supreme Court 80, 81 in THEN \& NOW: STORIES OF LAW AND PROGRESS (2013). Therefore, a random sample of sufficient numbers of Supreme Court decisions should provide a fairly accurate picture of the types of claims raised in lower federal courts in the nineteenth century.

${ }_{77}$ Compared to federal constitutional law, state constitutional law is relatively easy to alter by populist means. America's "fifty states have held 233 constitutional conventions [and] adopted 146 constitutions" since 1776. JOHN J. DinAN, THE AMERICAN STATE CONSTITUTIONAL TRADITION 1 (2009). In contrast, the federal government has not convened a constitutional convention since 1787. Moreover, it is much easier to amend state constitutions than the U.S. Constitution. See Donald S. Lutz, Toward a Theory of Constitutional Amendment, in RESPONDING to IMPERFECTION: THE THEORY AND PRACTICE OF CONSTITUTIONAL AMENDMENT 237, 248-49 (Sanford Levinson, ed.) (1995). Whereas democratic majorities can overrule state court constitutional decisions by amending the state's constitution, it is practically impossible for democratic majorities to overrule a federal constitutional decision by amending the U.S. Constitution.
} 


\section{Polymorphous Public Law Litigation}

David Sloss, Draft, January 2014

\section{The Transition from Private Law to Public Law}

Figure One summarizes the main results of phase one data analysis. ${ }^{78}$ Between 1801 and 1888, more than $60 \%$ of the Supreme Court's cases were private law cases. Since 1936, though, public law cases have occupied more than $65 \%$ of the Supreme Court docket. The shift from a private law to public law is significant because it multiplies the effect of constitutionalization. The quantitative analysis summarized in Figures Three to Seven below measures judicial reliance on constitutional law as a percentage of public law cases. Figure One shows that the percentage of public law cases on the Supreme Court docket has increased over time. Hence, if one measured judicial reliance on constitutional law as a percentage of the Court's total caseload, instead of measuring it as a percentage of public law cases, the degree of constitutionalization would be even greater. $^{79}$

In addition to recording the split between private and public law, phase one data also shows the division, within the class of PG cases, between cases involving federal government actors and those involving state and local government actors. Figure Two shows that the proportion of federal cases on the Supreme Court docket has declined, while the proportion of state/local cases has increased. ${ }^{80}$ In the pre-Civil War era, most public law cases involved federal government actors. From the 1860 s to the 1970 s (periods 3 to 7 ), the ratio of federal cases to state/local cases was fairly even and fairly constant, except during period 6, when federal cases predominated. Period 8, from 1972 to 2005, is the only period when the Supreme Court decided more state/local cases than federal cases. $^{81}$

${ }^{78}$ Figure One summarizes the results of phase one analysis, but the numbers are adjusted to correct for errors in phase one data. See Appendix, Table One, for an explanation of the error analysis. All point estimates in Figure One represent the mid-points of the estimated range of values. The "public law" category includes all cases classified as PG, including cases that were eventually excluded from phase two because they did not satisfy the definition of "public law cases." See supra notes 60 and 65. The "other" category includes cases classified as FS, GG, and MP. See supra note 59.

${ }^{79}$ This statement assumes that the Court is more likely to apply constitutional law in public law cases than in private law cases. I have not tested that assumption empirically, but I am fairly confident it is correct.

80 "Federal" cases are those in which a federal government actor is a party, regardless of whether the case originated in federal court. "State/local" cases are those in which a state or local government actor is a party, regardless of whether the case originated in state court.

${ }^{81}$ In phase one, all PG cases were further categorized based on the identity of the government party. The five sub-categories are federal, state, local, territorial (for cases involving a territorial government), or mixed (where federal and state government actors were co-parties). If state and local government actors are co-parties, the case is coded as "state." The "other" category in Figure Two includes territorial cases and mixed cases. Unlike Figure One, the data in Figure Two does not incorporate an error analysis because the phase two analysis did not uncover any systematic error in the phase one categorization of cases as "federal," "state," or "local." 
Figure One

The Percentage of Public Law and Private Law Cases on the Supreme Court Docket

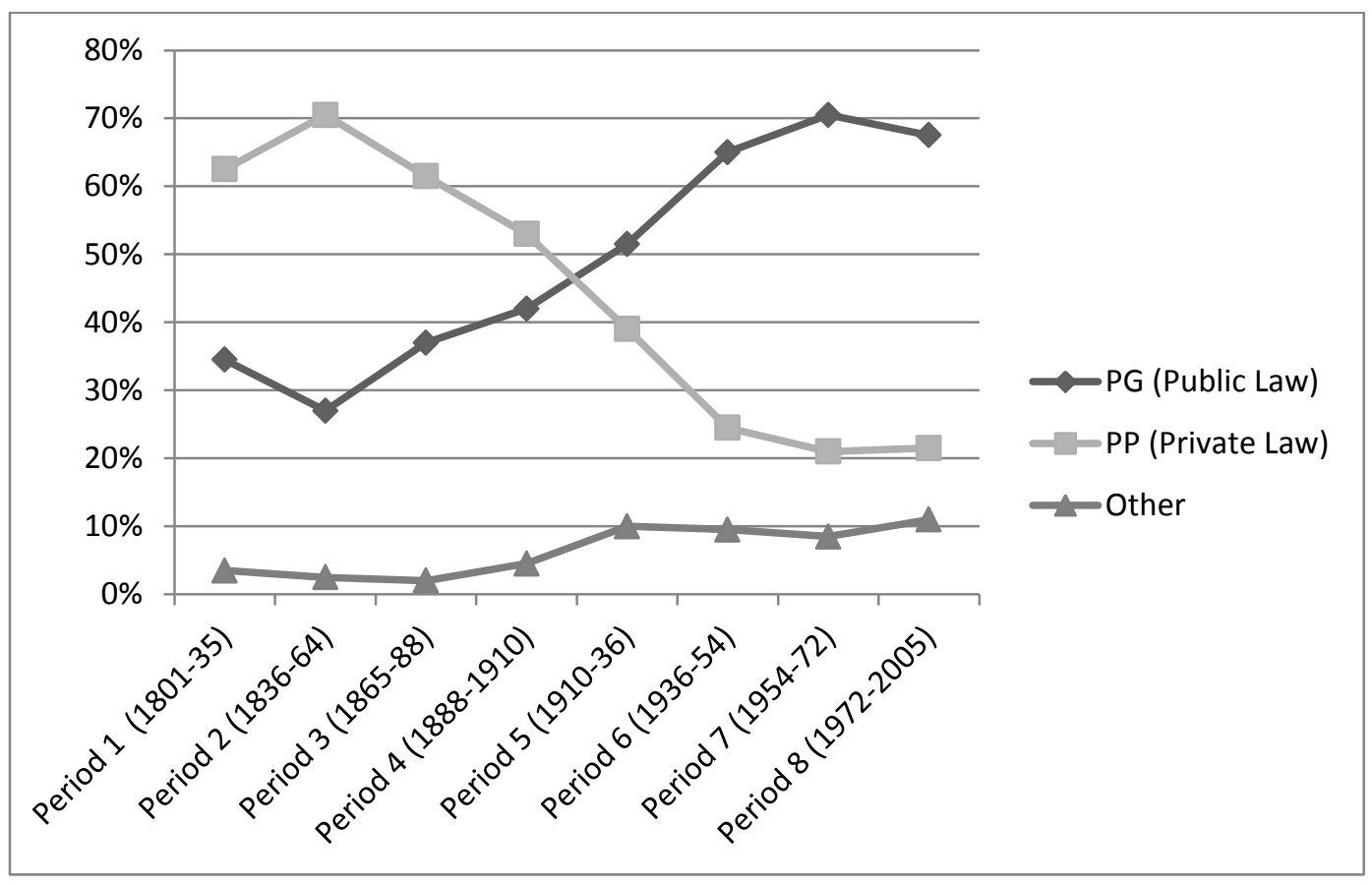

The increasing percentage of state/local cases on the Supreme Court docket is significant because the Court has always relied more heavily on constitutional law in state/local cases than in federal cases. ${ }^{82}$ Thus, the rising percentage of state/local cases on the Court's docket provides a partial explanation for constitutionalization. However, as illustrated in Figures Six and Seven below, there is evidence of constitutionalization within the class of federal cases, and separately within the class of state/local cases. Therefore, the increasing percentage of state/local cases, and the corresponding decline in the percentage of federal cases, does not provide a complete explanation of constitutionalization.

${ }^{82}$ See Figures Six and Seven below. See also Appendix, Table Three. 


\section{Figure Two \\ Percentage of Public Law Cases on the Supreme Court Docket Involving Federal vs. State \& Local Government Actors}

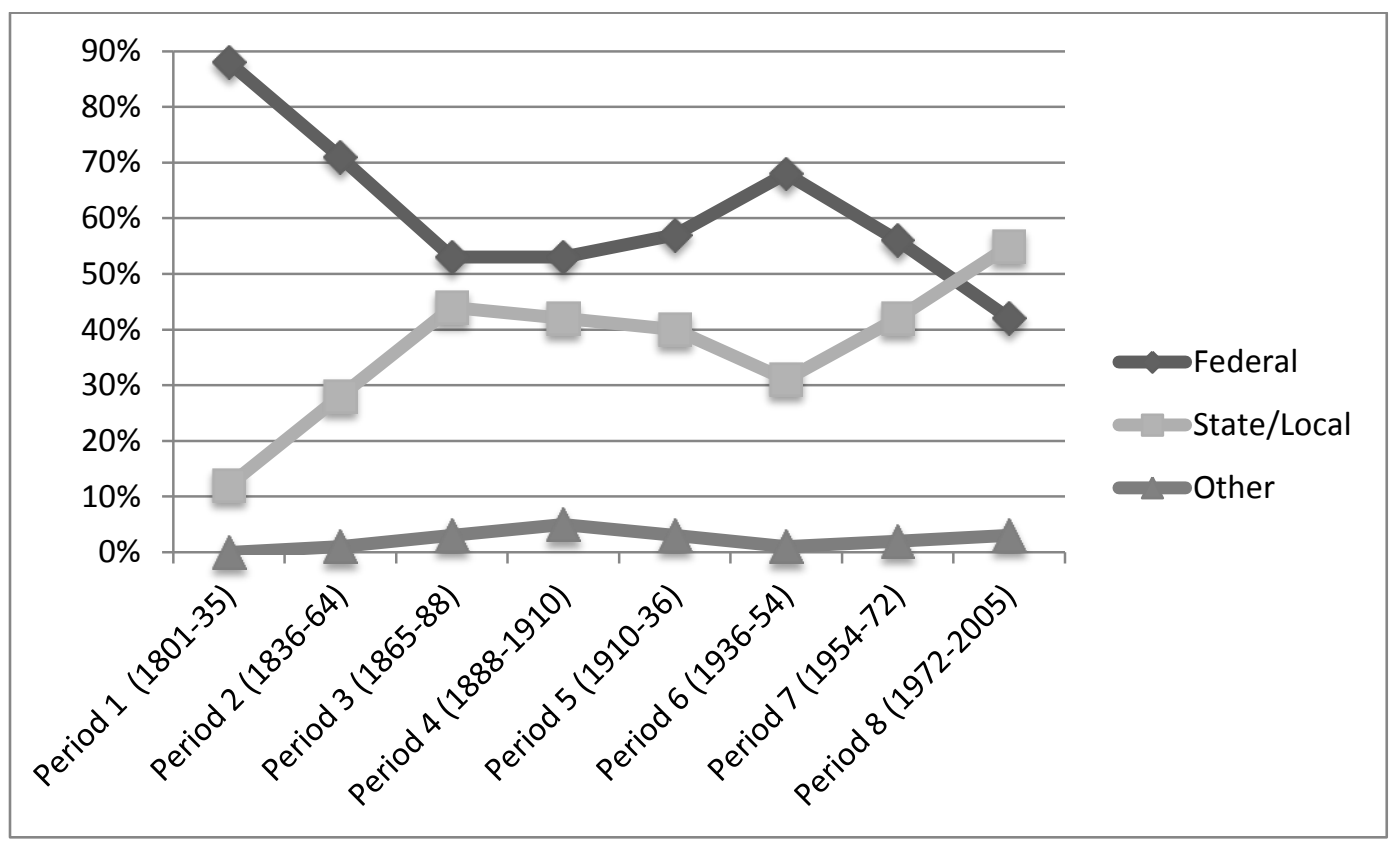

\section{The Constitutionalization of American Public Law}

Figure Three illustrates the constitutionalization of American public law. ${ }^{83}$ It shows that constitutional law has displaced other sources of law as the dominant public law discourse in federal courts. Figure Three also shows that, in the pre-Civil War era, international law claims prevailed over constitutional claims, and international law was the main source of non-statutory law that the Court applied to decide public law cases.

\footnotetext{
${ }^{83}$ The data in Figure Three is based on the phase two database. The percentages are estimates of the percentage of public law cases in which the Supreme Court applied international law and constitutional law, respectively, to help resolve claims alleging unlawful government conduct. The denominator for all percentages is the number of cases in the phase two database for a given period that the Court decided on the merits. The numerator is the number of those cases in which the Court applied international law, or constitutional law, or neither international nor constitutional law. See Appendix, Table Two.

The phase two database contains detailed information about the extent to which the Court relied on common law and state law, as well as international law and federal constitutional law. Since courts and litigants invoke federal statutes in almost all public law cases, the database does not record reliance on federal statutes, except to show cases where courts and litigants did not invoke any source of law other than federal statutes. The database does not distinguish between statutes and regulations for this purpose.
} 


\section{Polymorphous Public Law Litigation}

David Sloss, Draft, January 2014

The quantitative difference between judicial application of international law and constitutional law is statistically significant for every period shown in Figure Three, except period 3. The difference between judicial application of constitutional law and "neither international nor constitutional law" is statistically significant for every period except period 6 . The difference between international law and the "neither" category is not statistically significant in periods 1 and 2 , but is statistically significant in later periods. ${ }^{84}$

\section{Figure Three \\ Percentage of Supreme Court Decisions in Public Law Cases In Which the Court Applied Constitutional versus International Law}

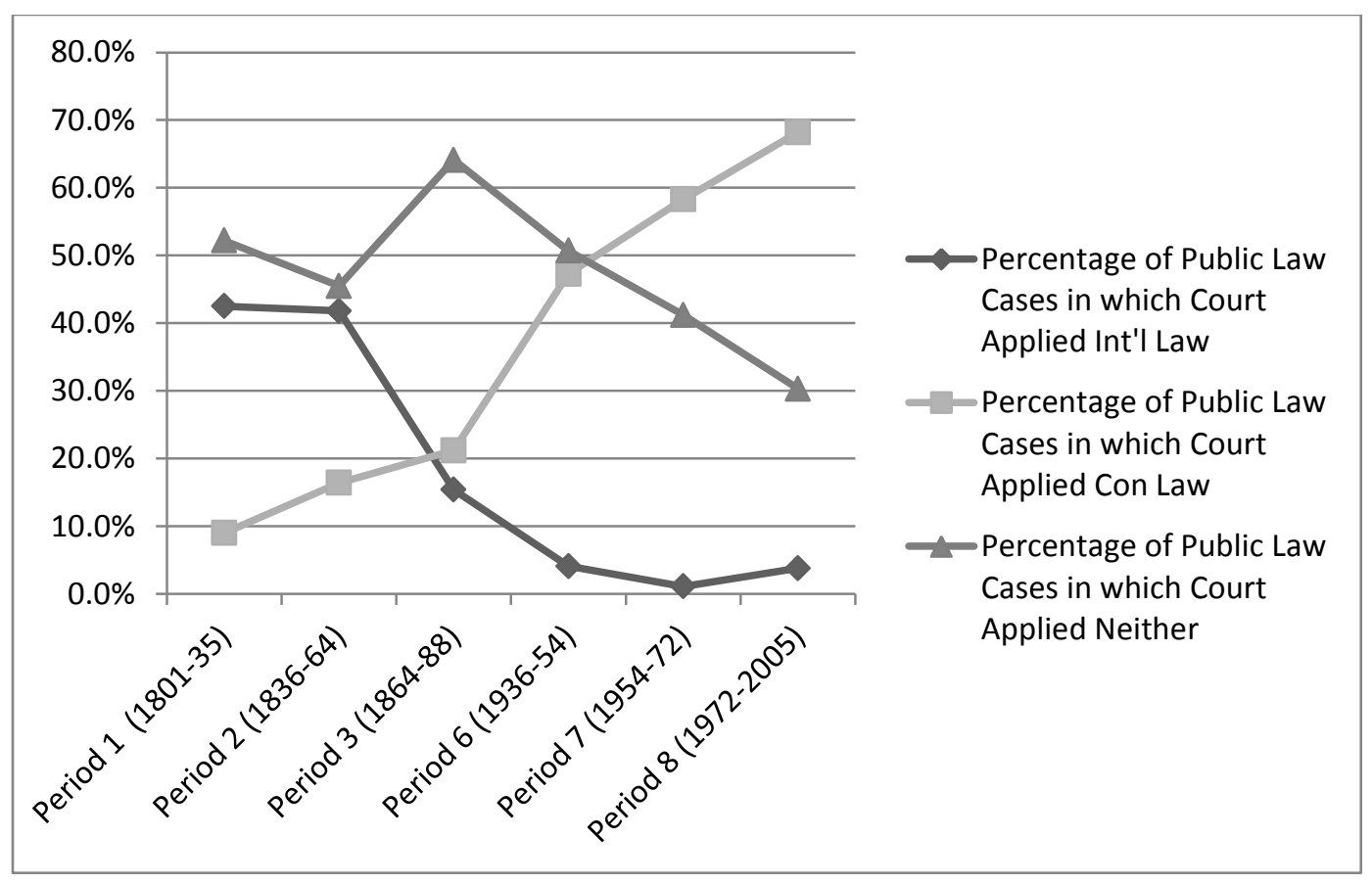

Figure Three illustrates the decline of polymorphous judicial review and the corresponding rise of constitutionalization since World War II. The chart shows that the Court applied a polymorphous model from the Founding until about the 1950s. Even in period 6, after judicial reliance on international law had waned, the Court decided approximately $45-60$ percent of its public law cases by applying sources other than constitutional law. ${ }^{85}$ However, during and after the Warren Court, constitutional law eclipsed every other source of law as the dominant public law discourse in the Supreme Court.

\footnotetext{
${ }^{84}$ Throughout this paper, the statement that a measurement is statistically significant means that it is significant at a 95\% confidence level. See Appendix, Table Two, for estimates of confidence intervals associated with the data depicted in Figures Three, Four and Five.

${ }^{85}$ See Appendix, Table Two.
} 


\section{Polymorphous Public Law Litigation}

Figures Four and Five show that the type of law applied by courts is consistent with the type of law invoked by private parties. Courts typically apply international law to decide cases where private parties allege international law violations by government actors. Similarly, courts typically apply constitutional law to decide cases where private parties allege constitutional law violations by government actors. Thus, perhaps lawyers, not judges, have driven the trend toward greater constitutionalization of public law. On the other hand, lawyers typically invoke arguments that they think have the best chance of winning. Therefore, lawyers' tendency to rely more on constitutional law in later historical periods probably reflects their judgment about the receptivity of courts to different types of legal arguments. ${ }^{86}$

Figure Four - The Decline of International Law

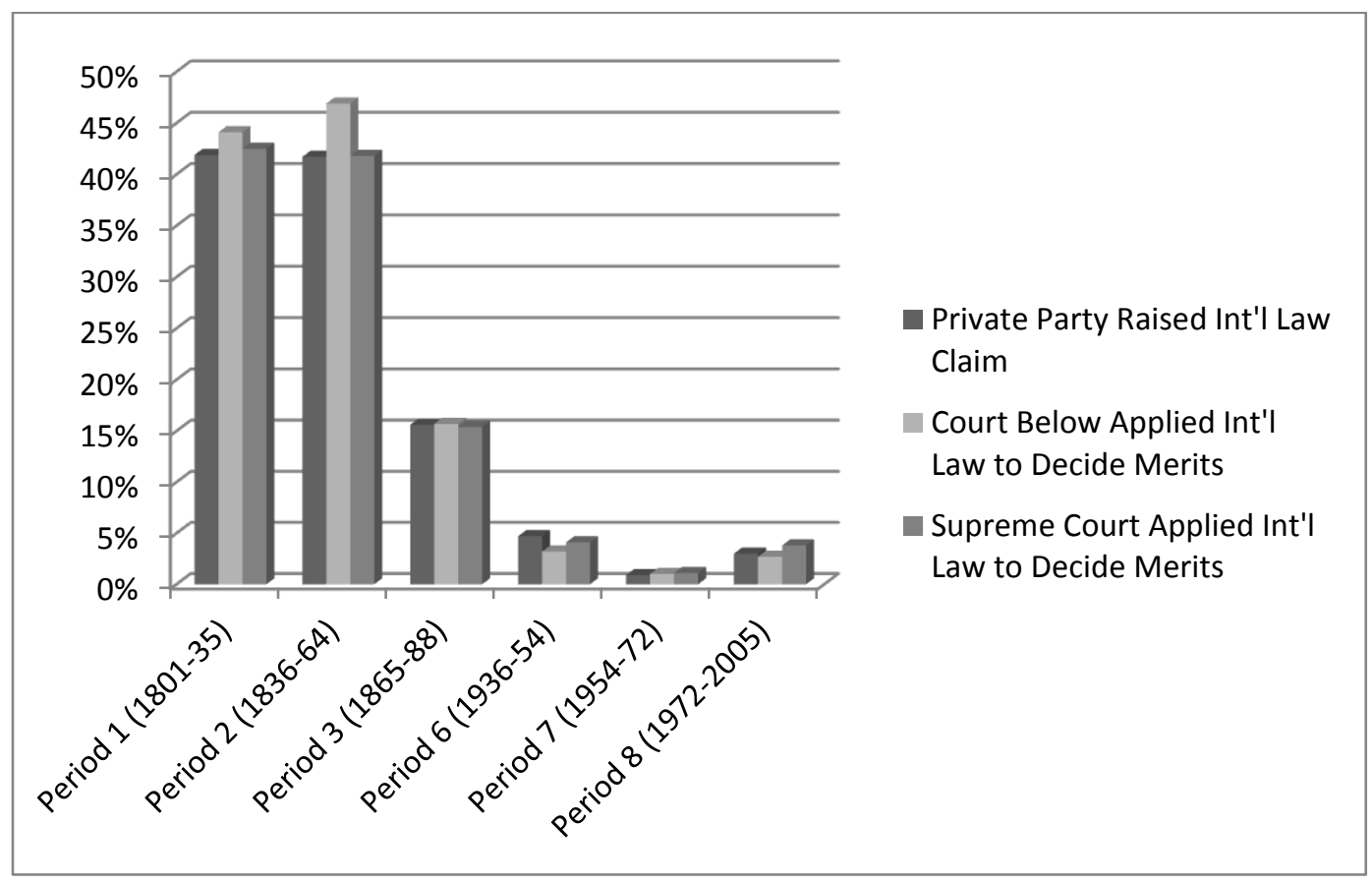

In Figure Four, there is no statistically significant difference among the three discrete measurements within a particular time period. Whether one uses Supreme Court decisions, lower court decisions, or private party claims as a metric to measure reliance on international law, the results are statistically

${ }^{86}$ For Figures Four and Five, the percentage of cases where the private party raised an international law claim, or a constitutional law claim, is calculated as a percentage of the total cases in the database for that period. In contrast, the percentages for judicial decisions are calculated as a percentage of decisions on the merits in a given time period. The "court below" in Figures Four and Five is the last court to address the case before it reached the Supreme Court. See Appendix, Table Two. 


\section{Polymorphous Public Law Litigation}

David Sloss, Draft, January 2014

indistinguishable within a particular time period. Similarly, in Figure Five, there is no statistically significant difference among the three discrete measurements of reliance on constitutional law within a particular time period.

Looking at changes over time for international law (Figure Four), there was no statistically significant difference between periods 1 and 2, or between periods 6,7 , and 8 . However, there was a statistically significant decline in reliance on international law between periods 2 and 3, and again between periods 3 and $6 .{ }^{87}$ With respect to Figure Five, there was a statistically significant increase in reliance on constitutional law from period 1 to 3 , from period 3 to 6 , and from period 6 to $8{ }^{88}$ However, the differences between adjacent periods in Figure Five are not statistically significant.

Figure Five - The Rise of Constitutional Law

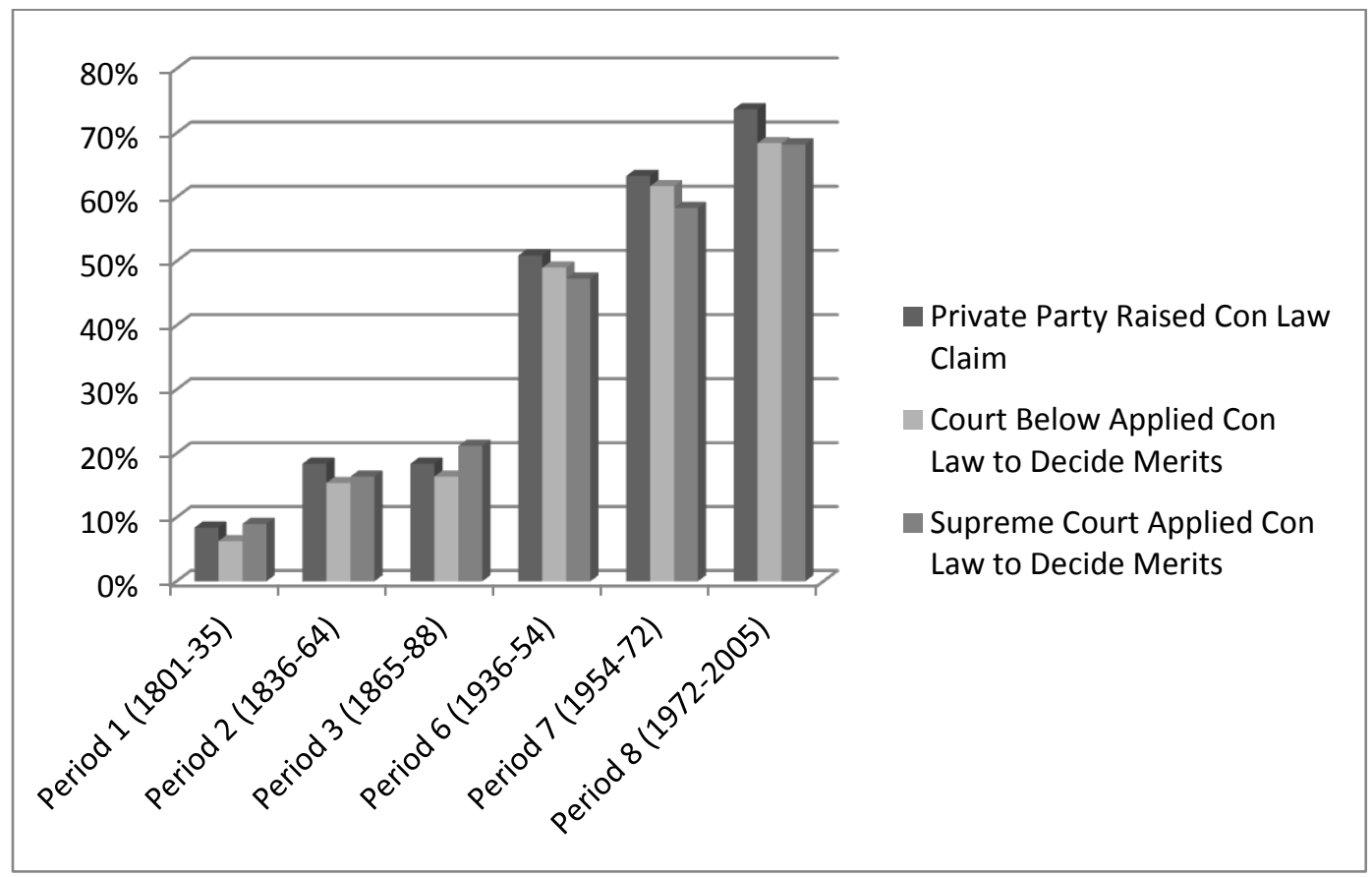

Figures Three and Five demonstrate that constitutional law has displaced other sources of law as the dominant public law discourse in the Supreme Court. Or, to state the point differently, the constitutionalized model of public law

\footnotetext{
${ }^{87}$ See Appendix, Table Two.

${ }^{88}$ For the transition from period 1 to 3 , the rise in private party claims based on constitutional law is not (quite) statistically significant at the $95 \%$ confidence level. However, the other two measures are statistically significant at the $95 \%$ level. For the transitions from period 3 to 6 , and from period 6 to 8, all three measures are statistically significant. See Appendix, Table Two.
} 


\section{Polymorphous Public Law Litigation}

David Sloss, Draft, January 2014

litigation has supplanted the polymorphous model of public law litigation that prevailed in the nineteenth century.

If one divides public law cases between federal cases and state/local cases, a somewhat different picture emerges. Figures Six and Seven, respectively, present data about public law cases involving alleged violations by federal government actors, ${ }^{89}$ and by state and local government actors. ${ }^{90}$

\section{Figure Six \\ Alleged Violations by Federal Government Actors}

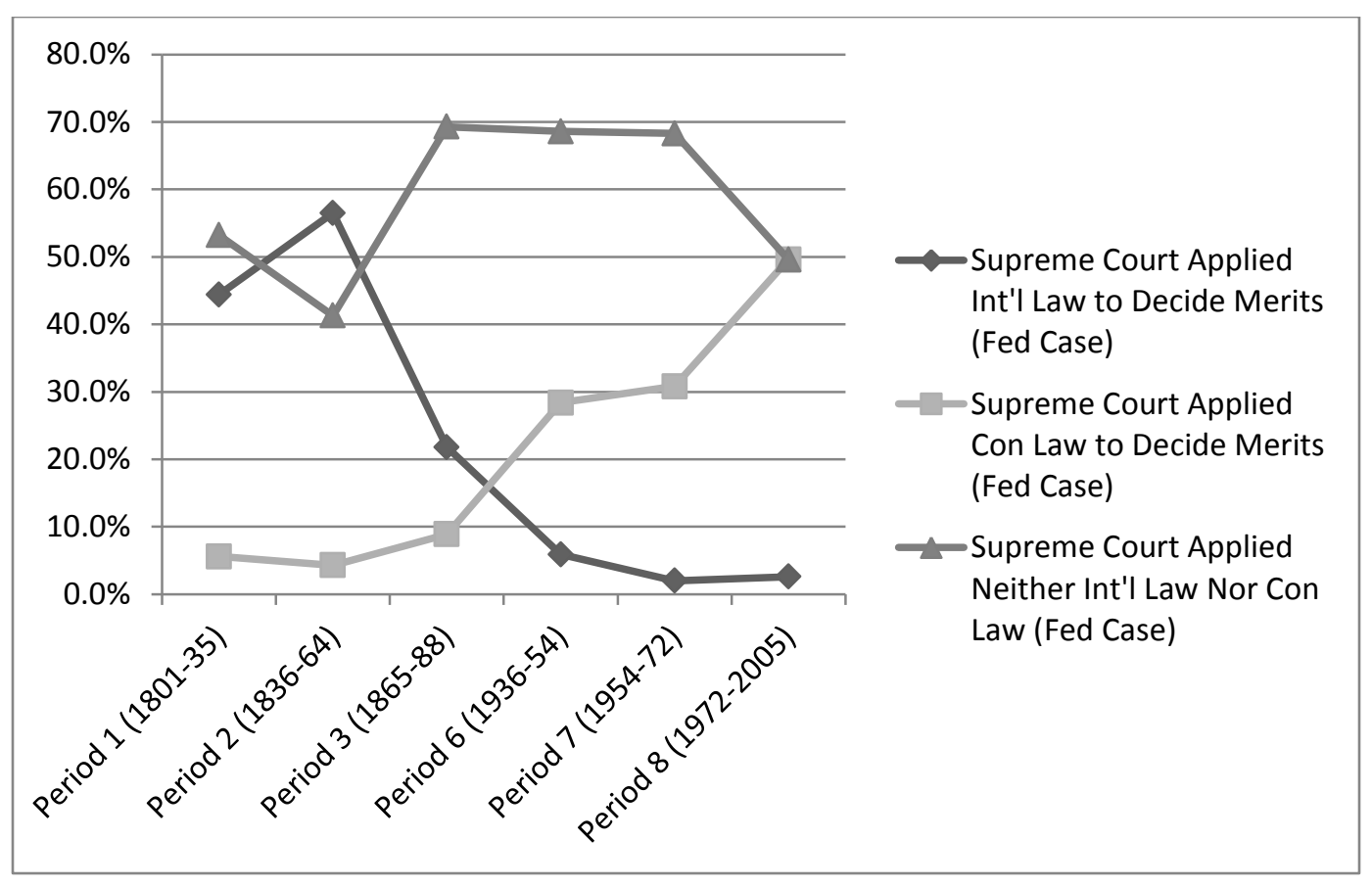

A comparison between Figures Six and Seven is illuminating. First, note that federal courts have always relied more heavily on constitutional law in

\footnotetext{
${ }^{89}$ In Figure Six, the denominator for all percentages is the number of federal cases in the phase two database for a given period that the Court decided on the merits. The numerator is the number of those cases in which the Court applied international law, or constitutional law, or neither international nor constitutional law. See Appendix, Table Three.

${ }^{90}$ In Figure Seven, the percentages are calculated in the same way as in Figure Six, except that the numerators and denominators include state/local cases, instead of federal cases. See Appendix, Table Four. In period 1, there were very few public law cases involving claims against state and local government actors. See Figure Two supra. In Figures Seven and Eight, where state/local cases are segregated from federal cases, I do not include data for period 1 for state/local cases because there are too few cases to support any significant findings.
} 


\section{Polymorphous Public Law Litigation}

David Sloss, Draft, January 2014

state/local cases than in federal cases. ${ }^{91}$ For state/local cases, reliance on constitutional law ranged from a low of about forty-three percent in periods 2 and 3 , to a high of about ninety percent in periods 6 and 7. In contrast, for federal cases, reliance on constitutional law ranged from a low of less than ten percent in periods 1 to 3 , to a high of about fifty percent in period 8 .

\section{Figure Seven \\ Alleged Violations by State \& Local Government Actors}

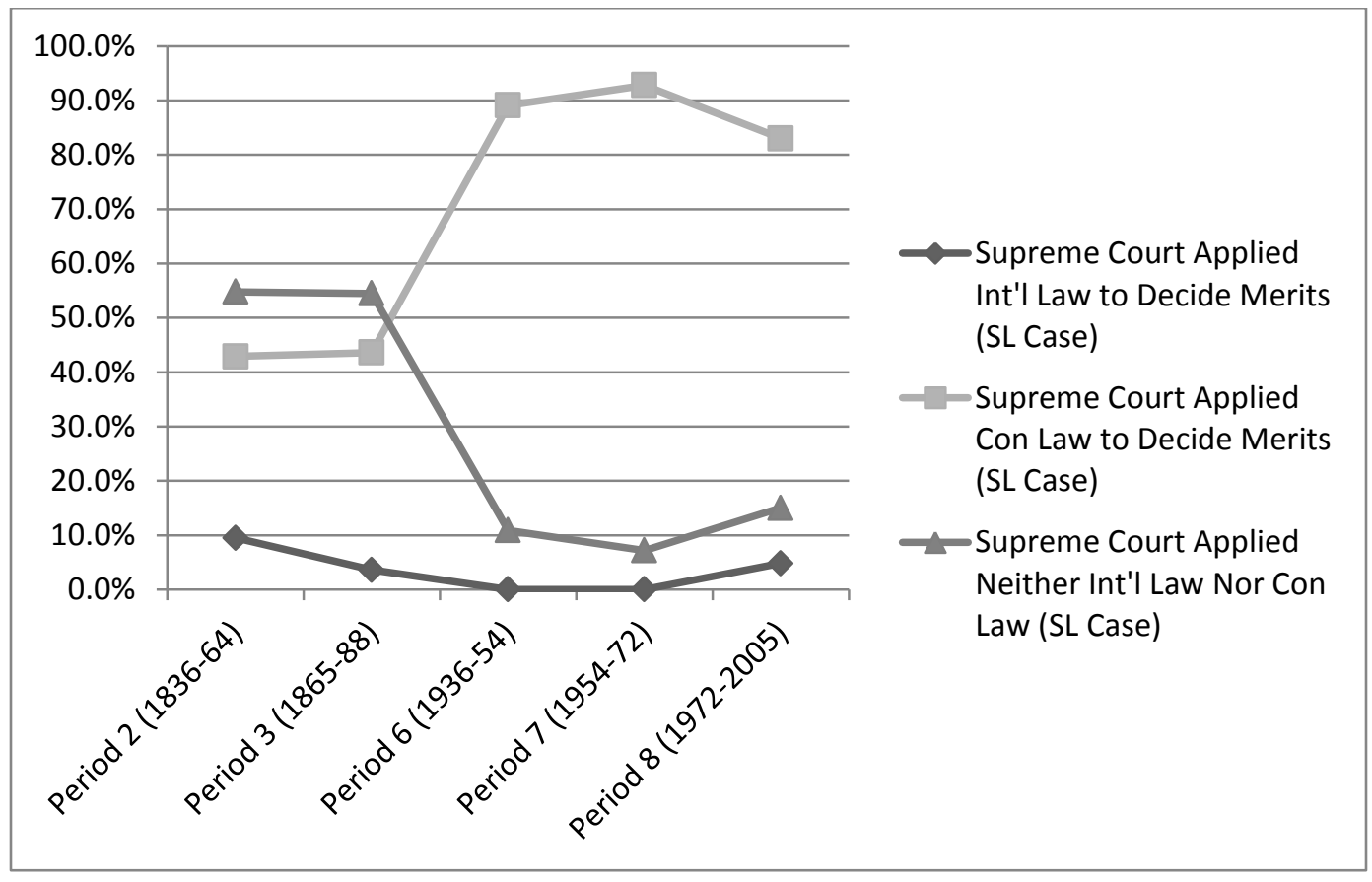

Second, note that constitutionalization occurred earlier for state and local cases than it did for federal cases. As shown in Figure Seven, litigation of state/local cases became heavily constitutionalized somewhere between periods 3 and 6. However, as shown in Figure Six, litigation of federal cases did not really become constitutionalized until period $8 .^{92}$

Third, note the difference between federal cases and state/local cases in the nineteenth century regarding application of international law. International law claims accounted for about $44 \%$ of federal cases in period $1,56 \%$ of federal cases in period 2 , and $22 \%$ of federal cases in period $3 .{ }^{93}$ In contrast, international

\footnotetext{
${ }^{91}$ This proposition is also true if one uses private party claims, rather than judicial decisions, as a metric for measuring reliance on constitutional law. See Appendix, Tables Three and Four.

${ }^{92}$ Data for periods 4 and 5 is absent, but it is unlikely that the percentage of federal cases in which the Court applied constitutional law was higher in period 4 or 5 than it was in periods 6 and 7 .

${ }^{93}$ See Appendix, Table Three.
} 


\section{Polymorphous Public Law Litigation}

claims never accounted for more than $10 \%$ of the state/local cases in any period. ${ }^{94}$ For the federal cases depicted in Figure Six, there was a statistically significant decline in reliance on international law between periods 2 and 3, and again between periods 3 and $6 .{ }^{95}$ For the state/local cases displayed in Figure Seven, there was no statistically significant change in reliance on international law across time periods. The Supreme Court has never relied heavily on international law to decide state/local cases.

Focusing on Figure Six, it bears emphasis that the polymorphous model prevailed for federal cases from the Founding until the 1970 s. ${ }^{96}$ Before the Civil War, most claims against federal officers involved international law, common law and statutes. (The "neither" category includes both common law and statutory claims.) In period 3, immediately after the Civil War, statutory and common law claims supplanted international law claims to some extent. Even so, litigants who raised claims against federal government actors in period 3 were more likely to frame those claims in terms of international law, not constitutional law. ${ }^{97}$ There was a statistically significant increase in the percentage of constitutional law claims between periods 3 and 6. However, in both periods 6 and 7, the Supreme Court was much more likely to decide claims against federal government actors by applying statutes, rather than constitutional law. ${ }^{98}$

\section{E. The Decline of the Polymorphous Model of Public Law Litigation}

The last section analyzed the type of law courts apply in public law cases, emphasizing the distinction between international and constitutional law. To assess the tension between judicial review and popular sovereignty, it is also important to consider the nature of the government conduct being challenged. Compare claims challenging legislative action to those challenging executive or administrative action. Judicial decisions invalidating statutes exacerbate the tension between judicial review and popular sovereignty because the court applies its judicial power to invalidate a law adopted by majority vote in a popularly

\footnotetext{
${ }^{94}$ See Appendix, Table Four.

${ }^{95}$ See Appendix, Table Three.

96 Here, I use the term "polymorphous" to refer to the fact that, for federal cases, nonconstitutional claims prevailed over constitutional claims until the 1970s.

${ }^{97}$ For federal cases in period 3, using private party claims as a metric, there was a statistically significant difference between the incidence of international law and constitutional law claims. See Appendix, Table Three. However, using Supreme Court decisions as a metric, the difference between international law cases and constitutional law cases was not (quite) statistically significant at the 95 percent level.

${ }^{98}$ Common law claims largely disappeared near the beginning of period 6 , due to the Supreme Court decision in Erie Railroad Co. v. Tompkins, 304 U.S. 64 (1938). The incidence of international law claims declined significantly between periods 3 and 6. See Appendix, Table Three. Hence, in periods 6 to 8, most federal cases involved either statutes or constitutional law.
} 


\section{Polymorphous Public Law Litigation}

elected legislature. ${ }^{99}$ In contrast, a judicial decision holding that an unelected government officer violated a statute is broadly consistent with principles of popular sovereignty: the court applies its judicial power to ensure that the government officer complies with a law created by a democratic process. ${ }^{100}$ Several permutations are possible, depending on the type of government conduct being challenged, the source of the legal norm applied, and other factors. The central point is that claims challenging the validity of legislation tend to exacerbate the tension between judicial review and popular sovereignty. In contrast, claims challenging the legality of executive or administrative action typically raise fewer concerns about conflicts between judicial review and popular sovereignty.

Figure Eight depicts changes over time in the percentage of public law cases challenging legislative action. The data in Figure Eight is based on claims and defenses raised by private parties, not judicial decisions by courts. Specific points are estimates of the percentage of cases in a given period where private parties raised claims or defenses challenging the validity of legislation. Focus, first, on the middle line, which is an aggregate figure for all public law cases. There was a statistically significant increase in cases challenging legislation between periods 3 and 6 . However, there was no statistically significant change in the rate at which private parties challenged legislation across periods $1-3$, or across periods $6-8 .^{101}$

The top and bottom lines in Figure Eight divide public law cases between federal cases and state/local cases. The pattern for federal cases is similar to the pattern for total cases. There was a statistically significant increase in cases challenging federal legislation between periods 3 and 6 . However, there was no statistically significant change in the rate at which private parties challenged federal legislation across periods $1-3$, or across periods $6-8$. Before 1888 , private parties rarely raised claims or defenses challenging the validity of federal legislation. In the nineteenth century, most public law litigation with federal government actors involved challenges to federal executive or administrative action. $^{102}$

\footnotetext{
${ }^{99}$ See, e.g., United States v. Windsor, 133 S.Ct. 2675 (2013) (holding that the federal Defense of Marriage Act is unconstitutional).

${ }^{100}$ See, e.g., PPL Corp. v. Comm'r of Internal Revenue, 133 S.Ct. 1897 (2013) (in suit against Commissioner of Internal Revenue, holding that corporate taxpayer had statutory entitlement to tax credit).

${ }^{101}$ See Appendix, Table Five. The increase from period 1 to period 3 is not quite statistically significant at the $95 \%$ level.

${ }^{102}$ In periods 1-3, fewer than five percent of federal cases involved challenges to legislative action. See Appendix, Table Five.
} 
Figure Eight

Public Law Cases Challenging the Validity of Legislation

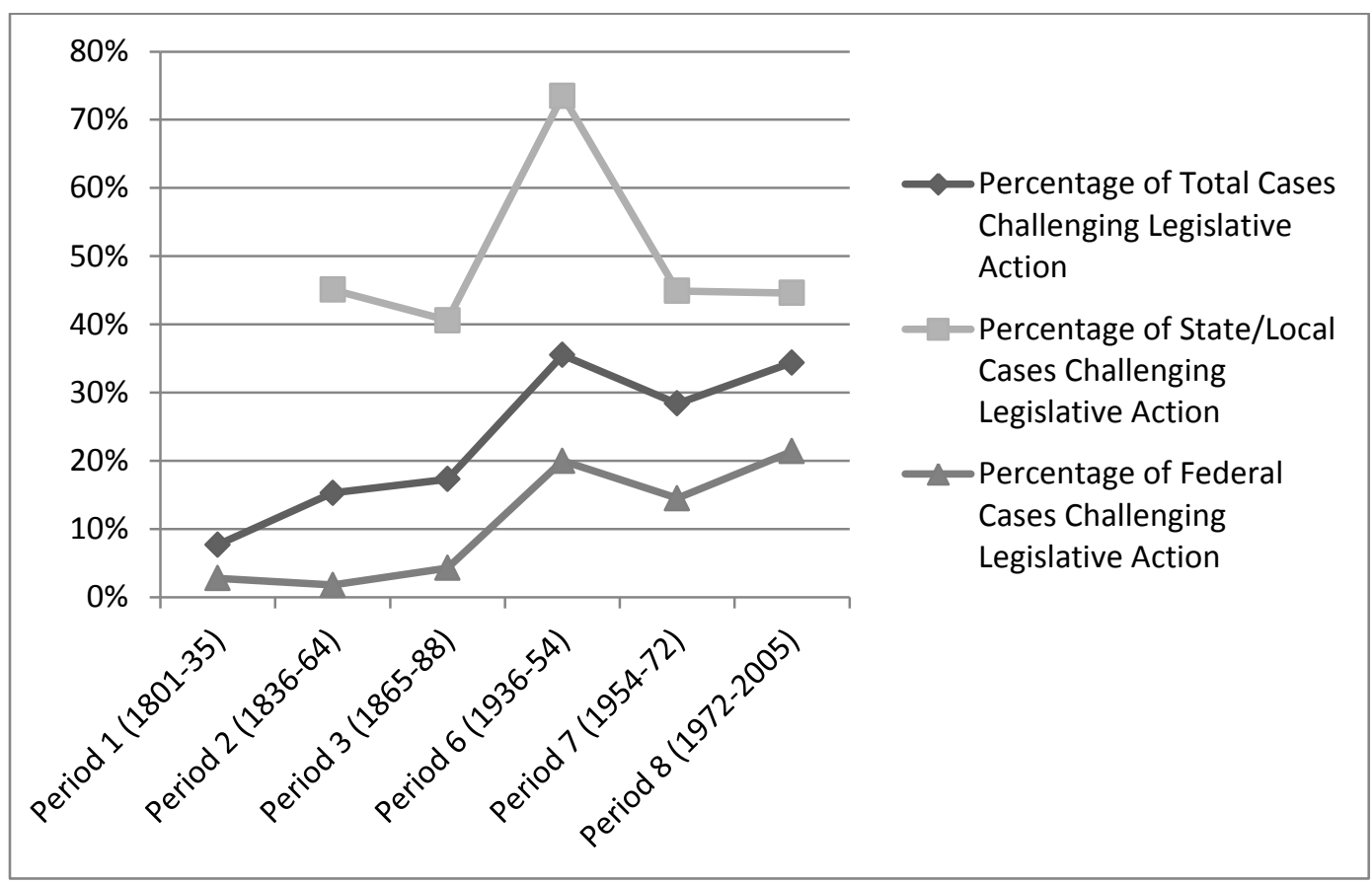

The top line in Figure Eight depicts the percentage of state/local cases where private parties challenged the validity of state or local legislation. ${ }^{103}$ The contrast with federal cases is striking. Even in the nineteenth century, cases challenging state or local legislation were quite common. Indeed, there was no statistically significant change in the percentage of state/local cases challenging legislation across periods $2,3,7$, and 8 . In period 6 , there was a statistically significant increase in cases challenging state and local legislation. ${ }^{104}$ The sharp, temporary rise in period 6 may have been a remnant from the Lochner era. The Supreme Court may have purposefully granted certiorari in numerous cases to reject Lochner-type claims challenging state or local legislation. ${ }^{105}$

The data summarized in Figure Nine combines information about the type of government conduct challenged (shown in Figure Eight) with information

${ }^{103}$ As noted above, the separate data on state/local cases does not include data for period 1. See supra note 91.

${ }^{104}$ The total number of state/local cases in the phase two database for periods $2,3,6$, and 7 is fairly small. Nevertheless, the spike in cases challenging state and local legislation in period 6 is statistically significant. See Appendix, Table Five.

${ }^{105}$ At least one other fact supports this hypothesis. The phase two database shows that private parties had a lower winning percentage in the Supreme Court in period 6 than at any other time in Supreme Court history. 


\section{Polymorphous Public Law Litigation}

David Sloss, Draft, January 2014

about the type of legal claim raised (shown in Figures Four and Five). A claim is classified as countermajoritarian if the private party both raised a constitutional claim and challenged the validity of legislation. A claim is classified as majoritarian if the private party neither raised a constitutional claim nor challenged the validity of legislation. Like Figure Eight, Figure Nine presents information about claims raised by private parties, not judicial decisions by courts. $^{106}$

\section{Figure Nine \\ The Decline of the Majoritarian Model}

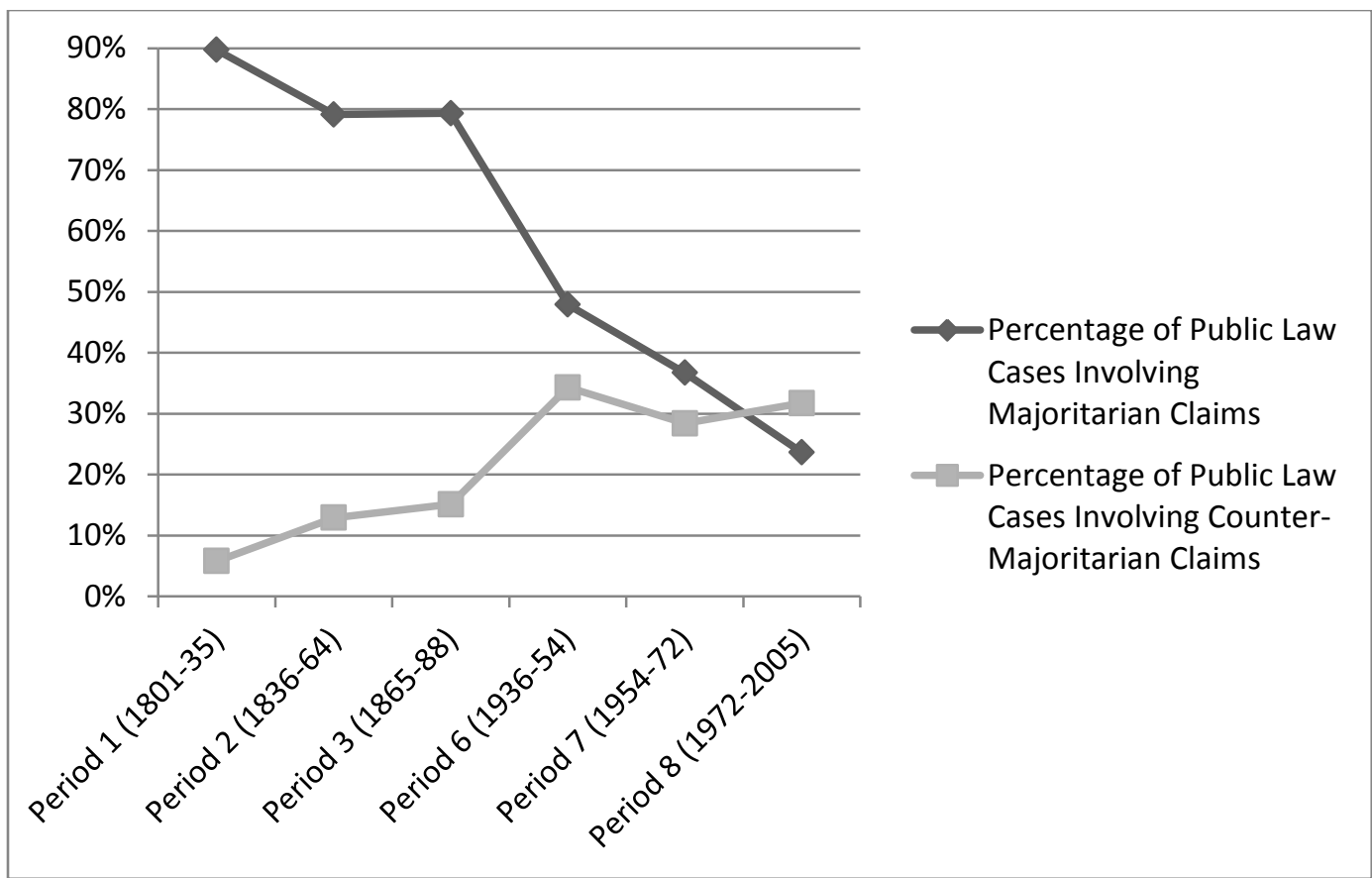

Figure Nine shows that there has been a sharp, steady decline in the percentage of public law cases involving majoritarian claims. To reiterate, a case is classified as majoritarian if the private party neither challenges legislation nor raises a constitutional law argument. The combination of lawyers' increasing reliance on constitutional law to frame arguments in public law cases, ${ }^{107}$ and their growing tendency to challenge the validity of legislation, ${ }^{108}$ explains the steady decline in majoritarian claims. The percentage of public law cases involving majoritarian claims dropped from a high of almost ninety percent in period 1, to a

\footnotetext{
${ }^{106}$ In Figure Nine, the denominator for each percentage is the total number of cases in the phase two database for that period. The numerator is the number of cases in each period satisfying the above definitions of "majoritarian" and "countermajoritarian" claims, respectively.

${ }^{107}$ See Figure Five supra.

${ }^{108}$ See Figure Eight supra.
} 


\section{Polymorphous Public Law Litigation}

David Sloss, Draft, January 2014

low of less than twenty-five percent in period 8. This steady decline includes a statistically significant drop from period 3 to 6 , followed by another statistically significant drop from period 6 to $8 .{ }^{109}$

In sum, nineteenth century public law litigation generally conformed to a polymorphous model that minimized the tension between judicial review and popular sovereignty. Nineteenth century lawyers who challenged the legality of government conduct usually challenge executive or administrative action, not legislative action. Moreover, they usually raised claims based on statutes, international law, or common law, not constitutional law. In contrast, modern litigants are more likely to challenge legislative action than their nineteenth century predecessors, and they are more likely to raise constitutional claims. Greater reliance on constitutional law, combined with the increasing tendency to challenge legislative action, means that the modern, constitutionalized system of public law litigation exacerbates the tension between judicial review and popular sovereignty.

\section{F. Tentative Explanations for Constitutionalization}

Additional empirical analysis of periods 4 and 5 is needed to provide a detailed explanation of constitutionalization. That is the subject of a follow-on project. Still, it is possible to venture some tentative hypotheses.

First, the differences between federal cases and state/local cases suggest that distinct explanations are required for the two sets of cases. For state/local cases, the sharp rise in reliance on constitutional law between periods 3 and 6 may be related to the development of Lochner jurisprudence in periods 4 and $5 .^{110}$ Interestingly, though, the repudiation of Lochner at the beginning of period 6 did not reverse the process of constitutionalization for state/local cases to any significant degree. ${ }^{111}$ During the Lochner era, lawyers and judges became accustomed to invoking and applying constitutional law to resolve public law claims against state and local government actors. The habit apparently persisted after the Court repudiated Lochner.

\footnotetext{
109 See Appendix, Table Five. The Appendix also provides data that divides the information presented in Figures Eight and Nine between federal cases and state/local cases.

${ }^{110}$ For an excellent historical analysis of Lochner era jurisprudence, see EDWARD A. PURCELL, JR., Brandeis AND the Progressive CONSTITUtion: ERIE, THE JUdicial POWER, AND THE POLITICS OF THE FEDERAL COURTS IN TWENTIETH-CENTURY AMERICA 11-91 (2000).

111 Data about the degree of constitutionalization in the Lochner era is not currently available. However, in period 6, after the Court repudiated Lochner, private parties raised constitutional claims in $92 \%$ of the state/local cases, and the Supreme Court applied constitutional law in $89 \%$ of the state/local cases. See Appendix, Table Four. The corresponding percentages could not have been much higher, if at all, during the Lochner era.
} 


\section{Polymorphous Public Law Litigation}

For federal cases, Figure Six shows a significant decline in reliance on international law before there was a significant rise in reliance on constitutional law. Hence, the decline of international law and the rise of constitutional law require separate explanations. ${ }^{112}$ Professor Ramsey has shown that claims involving customary international law disappeared from the Supreme Court docket in the early twentieth century. ${ }^{113} \mathrm{He}$ contends that treaties and statutes supplanted customary international law in some fields, while constitutional law displaced customary international law in other areas. Additionally, "[m]any staples of international law adjudication in the nineteenth century - pirates, prizes, and privateers - faded or disappeared altogether." 114

In contrast to customary international law, the Supreme Court continued to handle numerous treaty cases in the early twentieth century. ${ }^{115}$ However, a 1925 amendment to the Judicial Code altered the rules for Supreme Court jurisdiction over treaty cases. ${ }^{116}$ Before 1925, jurisdictional statutes gave litigants an automatic right of appeal to the Supreme Court in most treaty cases. The 1925 amendment granted the Supreme Court broad discretion to refuse to entertain most of those cases. ${ }^{117}$ The Court apparently used its newly granted discretion to reduce the number of treaty cases on its docket.

Turning to the Court's increasing reliance on constitutional law in federal cases, Figure Six depicts two distinct spikes. The first spike occurred between periods 3 and 6, when the Court's reliance on constitutional law jumped from below ten percent to almost thirty percent. ${ }^{118}$ This spike may also be related to changes in jurisdictional statutes between 1888 and 1925 that granted the Supreme Court greater control over its docket. ${ }^{119}$

The second spike occurred between periods 7 and 8, when the Court's reliance on constitutional law in federal cases increased from about $31 \%$ in period 7 to almost $50 \%$ in period 8 . One could hypothesize that the change between

\footnotetext{
${ }^{112}$ Figure Six shows a decline in international law for federal cases between periods 2 and 3 . The Court's overall caseload increased from about 55 cases per year in period 2 to about 189 cases per year in period 3. In part, the growing caseload involved new issues for which international law did not provide answers. Thus, the declining percentage of international law cases may be partially attributable to the growth of the Court's caseload during this period.

${ }^{113}$ See Ramsey, supra note 15, at 234-38.

${ }^{114} I d$. at 225 .

115 See Michael Van Alstine, Treaties in the Supreme Court, 1901-1945, in ConTINUITY AND CHANGE, supra note 15, at 191-224.

${ }^{116}$ An Act to Amend the Judicial Code, 43 Stat. 936.

${ }^{117}$ See Van Alstine, supra note 115, at 224; Shapiro, supra note 76, at 82-84.

${ }^{118}$ See Appendix, Table Three. If one measures private party claims, rather than Supreme Court decisions, reliance on constitutional law increased from $6 \%$ to $34 \%$ between periods 3 and 6 . See id.

${ }^{119}$ See Shapiro, supra note 76, at 81-85.
} 
periods 7 and 8 was related to the Court's increasing focus on cases challenging federal legislation (as opposed to executive or administrative action). However, the data in the following table refutes this hypothesis. ${ }^{120}$ Between period 6 and period 8 , the percentage of federal cases in which private parties challenged legislation remained fairly constant. ${ }^{121}$ In contrast, the percentage of federal cases in which private parties raised constitutional claims increased significantly between periods 7 and 8, as did the percentage of federal cases in which the Court applied constitutional law. ${ }^{122}$ The sharp increase in constitutionalization of claims against federal government actors after 1972 is an important trend that has received too little scholarly attention. Further analysis is necessary to explain this development.

\section{Constitutionalization of Federal Cases in the Twentieth Century}

\begin{tabular}{|l|c|c|c|}
\hline & $\begin{array}{c}\text { Period 6 } \\
\text { (1936-54) }\end{array}$ & $\begin{array}{c}\text { Period 7 } \\
\text { (1954-72) }\end{array}$ & $\begin{array}{c}\text { Period 8 } \\
\text { (1972-2005) }\end{array}$ \\
\hline $\begin{array}{l}\text { Percentage of Federal Cases } \\
\text { in Which Private Party } \\
\text { Challenged Legislation }\end{array}$ & $35.5 \%$ & $28.4 \%$ & $34.4 \%$ \\
\hline $\begin{array}{l}\text { Percentage of Federal Cases } \\
\text { in Which Private Party } \\
\text { Raised Con Law Claim }\end{array}$ & $34.2 \%$ & $36.8 \%$ & $59.3 \%$ \\
\hline $\begin{array}{l}\text { Percentage of Federal Cases } \\
\text { in Which Supreme Court } \\
\text { Applied Con Law }\end{array}$ & $28.4 \%$ & $30.8 \%$ & $49.6 \%$ \\
\hline
\end{tabular}

\section{III.}

\section{The Forgotten History of Nineteenth Century Public Law Litigation}

Conventional wisdom holds that public law litigation in the United States is a modern development. ${ }^{123}$ The novelty of public law litigation depends partly upon definition of the term. As defined above, public law cases accounted for a significant portion of the Supreme Court caseload in the nineteenth century. The Court decided more than 3000 public law cases in the nineteenth century. ${ }^{124}$ Part Three presents a narrative account of the history of nineteenth century public law litigation.

\footnotetext{
${ }^{120}$ The data in the table on this page is drawn from Tables Three and Five in the Appendix. Those tables provide confidence intervals for every estimate. The notes to those tables explain the derivation of the estimates.

${ }^{121}$ See Appendix, Table Five.

122 See Appendix, Table Three.

${ }^{123}$ See, e.g., Chayes, supra note 27, at 4.

${ }^{124}$ See Appendix, Table One.
} 


\section{Polymorphous Public Law Litigation}

Part Three is divided into four sections. The first section presents an overview of nineteenth century public law cases where the Court applied international law. The next two sections present case studies to illustrate application of a polymorphous model of public law litigation. The case studies address: 1) land claims arising from the 1803 Louisiana treaty and the 1819 Florida treaty; and 2) Chinese immigration cases from 1882 to 1905 . The final section summarizes key conclusions. The case studies demonstrate that federal courts can provide robust protection for individual rights without applying constitutional law and without invalidating legislation approved by popularly elected legislatures.

\section{A. Nineteenth Century International Law Claims}

Many nineteenth century cases involving judicial application of international law were private law cases. However, the nineteenth century Supreme Court also applied international law to help resolve numerous public law controversies. Broadly speaking, those public law cases include admiralty, real property, and other cases. Figure Ten shows that the mix of international law cases changed over time. ${ }^{125}$

During the Marshall Court (period 1), admiralty cases accounted for about two-thirds of the public law cases where litigants raised international law claims. ${ }^{126}$ Most of those admiralty cases involved allegations that a federal government agent seized private property in violation of customary international law. In many cases, the private party invoked international law as a defense to a prize proceeding or a civil forfeiture action initiated by the government. ${ }^{127}$ In other cases, the private party filed suit against a government actor to obtain damages or restitution for wrongful seizure of property. ${ }^{128} \mathrm{~A}$ few cases involved criminal prosecutions for piracy. ${ }^{129}$ Although many of the Marshall Court

\footnotetext{
${ }^{125}$ The percentages shown in Figure Ten are estimates based on the phase two database.

${ }^{126}$ See Figure Ten; see also BenJAmin MunN Ziegler, The InTERnAtional LaW of John MARSHALL: A STUDY OF FIRST PRINCIPLES (1939).

${ }^{127}$ See, e.g., The Josefa Segunda, 18 U.S. 338 (1820) (civil forfeiture action); The Friendschaft, 16 U.S. 14 (1818) (privateer captured vessel and initiated prize proceeding); The Julia, 12 U.S. 181 (1814) (War of 1812 prize case). The prize cases from this era include some captures by U.S. naval vessels and some captures by privateers. I count privateers as government agents if they acted on the basis of a commission issued by the government.

${ }^{128}$ See, e.g., The Apollon, 22 U.S. 362 (1824) (suit for damages against U.S. customs collector); Maley v. Jared Shattuck, 7 U.S. 458 (1806) (ordering federal officer to pay restitution for violation of customary international law). About $25 \%$ of the Marshall Court admiralty cases included in Figure Ten were initiated by private parties. The remaining $75 \%$ were initiated by government actors.

${ }^{129}$ See, e.g., United States v. Smith, 18 U.S. 153 (1820); United States v. Palmer, 16 U.S. 610 (1818). In Figure Ten, piracy cases count as "other," not "admiralty," because they are criminal cases.
} 
admiralty cases were private law disputes, ${ }^{130}$ all the cases included in Figure Ten are public law cases.

\section{Figure Ten \\ Supreme Court Public Law Cases Involving International Law, 1801-1888}

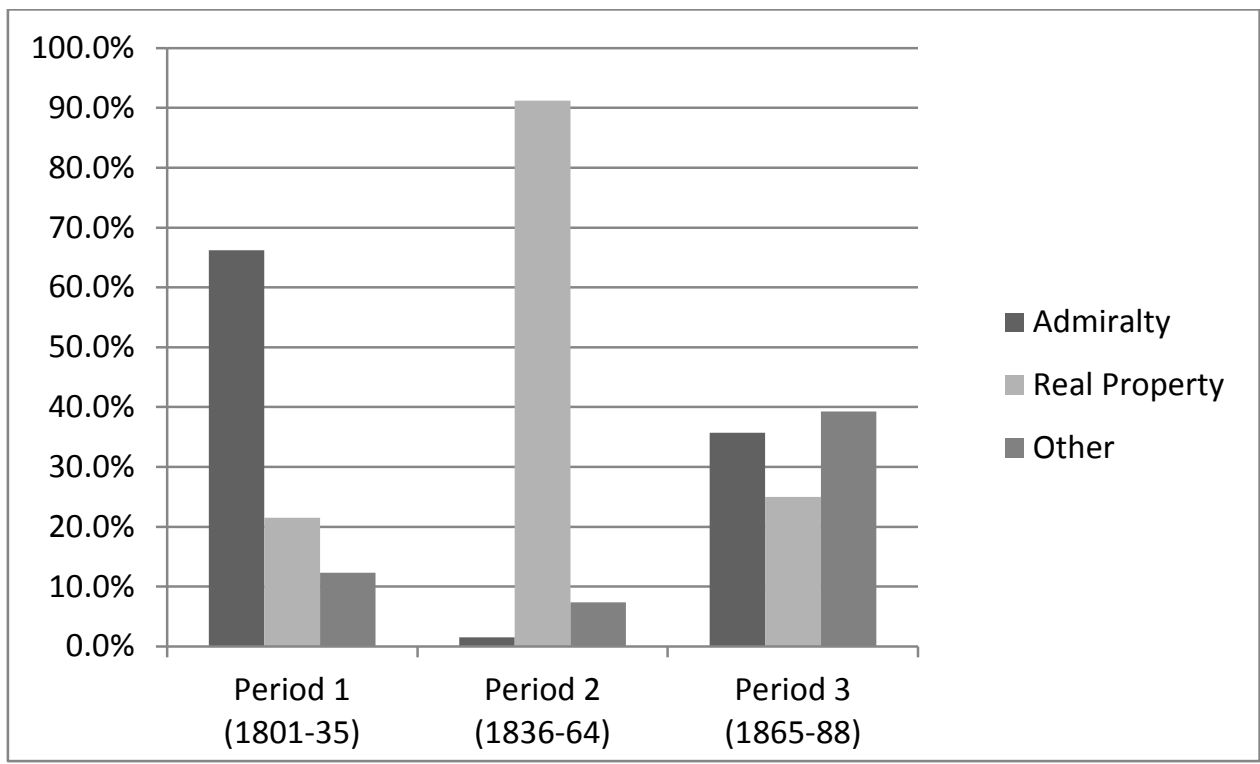

During the Taney Court (period 2), about ninety percent of the public law cases where litigants raised international law claims involved disputes over real property. ${ }^{131}$ Most of those cases arose under the 1803 treaty acquiring Louisiana from France, or the 1819 treaty acquiring Florida from Spain. ${ }^{132}$ Part III.B addresses land claims arising from these treaties.

In the aftermath of the Civil War (period 3), the public law cases where litigants raised international law claims included a mix of admiralty, real property, and other cases. ${ }^{133}$ The admiralty cases included many prize cases arising from the Civil War. ${ }^{134}$ The real property cases included many cases arising from the treaty acquiring California from Mexico; ${ }^{135}$ they were broadly similar to the

${ }^{130}$ See, e.g., La Nereyda, 21 U.S. 108 (1823); The Amiable Nancy, 16 U.S. 546 (1818).

${ }^{131}$ See Figure Ten.

${ }^{132}$ See Treaty for the Cession of Louisiana, U.S.-Fr., Apr. 30, 1803, 8 Stat. 200 [hereinafter Louisiana Treaty]; Treaty of Amity, Settlement and Limits, U.S.-Spain, Feb. 22, 1819, 8 Stat. 252 [hereinafter Florida Treaty].

${ }_{133}^{133}$ See Figure Ten.

${ }^{134}$ See, e.g., United States v. Farragut, 89 U.S. 406 (1874); The Peterhoff, 72 U.S. 28 (1866).

${ }^{135}$ Treaty of Peace, Friendship, Limits and Settlement, U.S.-Mex., Feb. 2, 1848, 9 Stat. 922 [hereinafter Treaty of Guadalupe Hidalgo]. 


\section{Polymorphous Public Law Litigation}

earlier Louisiana/Florida cases. ${ }^{136}$ The "other" cases defy generalization. Many arose under the Abandoned and Captured Property Act, ${ }^{137}$ a federal statute that authorized individuals to file claims against the United States to obtain compensation for property captured during the Civil War. ${ }^{138}$ Others involved treaties with Native American tribes, ${ }^{139}$ Chinese immigration cases, ${ }^{140}$ claims against state tax collectors, ${ }^{141}$ disputes over import duties, ${ }^{142}$ and a variety of other issues.

\section{B. Land Claims in Florida and Louisiana}

The United States acquired Louisiana from France under an 1803 treaty; it acquired Florida from Spain under an 1819 treaty. Both treaties protected the property rights of individuals who owned land under the prior sovereign. ${ }^{143}$ The treaties restated principles of customary international law, which held that transfer of territory between sovereign states does not affect individual property rights. Chief Justice Marshall summarized the law as follows:

The people change their allegiance; their relation to their ancient sovereign is dissolved; but their . . . rights of property, remain undisturbed .... Had Florida changed its sovereign by an act containing no stipulation respecting the property of individuals, the right of property in all those who became subjects or citizens of the new government would have been unaffected by the change; it would have remained the same as under the ancient sovereign. ... The king cedes that only which belonged to him; lands he had previously granted, were not his to cede. ${ }^{144}$

\footnotetext{
${ }^{136}$ See CARL B. Swisher, History of the SuPREME COURT OF THE United STATES, THE TANEY PERIOD: 1836-64, at 773-810 (1974).

${ }^{137}$ An Act to Provide for the Collection of Abandoned Property and for the Prevention of Frauds in Insurrectionary Districts within the United States, 12 Stat. 820 (Mar. 12, 1863).

${ }^{138}$ See Elizabeth Lee Thompson, Reconstructing the Practice: The Effects of Expanded Federal Judicial Power on Postbellum Lawyers, 43 Am. J. Legal Hist. 306 (1999). The Court of Claims decided more than 1500 cases arising under this statute between 1868 and 1875. See id. at 307-09. The Supreme Court decided approximately two dozen such cases in the decades after the Civil War, many of which involved application of international law. See Lee \& Sloss, supra note 18, at 131-32.

${ }^{139}$ See, e.g., The Cherokee Tobacco, 78 U.S. 616 (1870).

${ }^{140}$ See infra Part III.C.

${ }^{141}$ See Keith v. Clark, 97 U.S. 454 (1878).

${ }^{142}$ See, e.g., In re Cliquot's Champagne, 70 U.S. 114 (1866).

${ }^{143}$ See Louisiana Treaty, supra note 132, art. 3; Florida Treaty, supra note 132, art. 8. The 1848 treaty acquiring California from Mexico included a similar provision. See Treaty of Guadalupe Hidalgo, supra note 135 , art. 8.

${ }^{144}$ United States v. Percheman, 32 U.S. (7 Pet.) 51, 87 (1833).
} 


\section{Polymorphous Public Law Litigation}

From Marshall's standpoint, this was not merely a principle of international law; it was also a matter of fundamental rights. He said: "that sense of justice and of right which is acknowledged and felt by the whole civilized world would be outraged, if private property should be generally confiscated, and private rights annulled." 145

The principle was easier to state than to apply. Two factors presented difficulties. First, many claimants produced ostensible titles tainted by fraud. ${ }^{146}$ Given widespread allegations of fraud, Congress established administrative tribunals (known as land commissions) to distinguish between valid and fraudulent claims, and provided for judicial review of administrative decisions. ${ }^{147}$ The laws governing land commissions varied by region, but the commissions typically reported to Congress, whereupon Congress enacted statutes confirming individual titles as recommended by the commissioners. ${ }^{148}$ Second, the varied practices of French and Spanish officials who issued land grants before the U.S. acquisitions of Louisiana and Florida gave rise to a bewildering array of imperfect (or inchoate) titles. ${ }^{149}$ Supreme Court doctrine that developed between 1830 and 1850 established that individuals who held complete (or perfect) titles before the relevant treaty of cession did not have to present their claims to land commissions; the treaties confirmed the validity of perfect titles. ${ }^{150}$ However, individuals who held inchoate titles had to apply to land commissions, pursuant to procedures established by Congress, before the government would confirm their titles. $^{151}$

\footnotetext{
${ }^{145} \mathrm{Id}$. at 87.

${ }^{146}$ See Homer Cummings \& Carl McFarland, Federal Justice: Chapters IN the History OF JUSTICE AND THE FEDERAL EXECUTIVE 124-25 (1937).

${ }^{147}$ See, e.g., Act of Mar. 2, 1805, ch. 26, § 5, 2 Stat. 324, 327-28 (authorizing President to appoint commissioners for claims in Louisiana); Act of May 26, 1824, ch. 173, § 1, 2 Stat. 52 (providing for judicial review of land claims in Missouri); Act of May 8, 1822, ch. 129, 3 Stat. 709 (authorizing President to appoint commissioners for claims in Florida); Act of May 23, 1828, ch. 70, § 6, 4 Stat. 284 (providing for judicial review of land claims in Florida). See also Act of Mar. 2, 1805, ch. 26, 2 Stat. 324, 324-25 n.(a) (summarizing legislation between 1804 and 1844 relating to land claims in Louisiana and Florida).

${ }^{148}$ See, e.g., An Act for the confirmation of certain claims in the western district of Louisiana, and in the territory of Missouri, April 29, 1816, chap. 159; An Act confirming the titles to lots in the town of Mobile, and in the former province of West Florida, which claims have been favourably reported on by the commissioners appointed by the United States, May 7, 1822, chap. 122; An Act to confirm claims to lands in the district between the Rio Hondo and Sabine river, May 24, 1828, chap. 92.

${ }^{149}$ See Harry L. Coles, Jr., Applicability of the Public Land System to Louisiana, 43 Miss. Valley Hist. Rev. 39, 41 (1956).

${ }_{150}$ See David Sloss, Executing Foster v. Neilson: The Two-Step Approach to Analyzing SelfExecuting Treaties, 53 Harv. Int'l L. J. 135, 150-51 (2012); see also United States v. Roselius, 56 U.S. 31, 34 (1853); McDonogh v. Millaudon, 44 U.S. 693, 706 (1845).

${ }^{151}$ See, e.g., Menard's Heirs v. Massey, 49 U.S. 293, 306-07 (1850); United States v. Wiggins, 39 U.S. 334, 350 (1840).
} 


\section{Polymorphous Public Law Litigation}

Between 1830 and 1860, the Supreme Court decided approximately one hundred cases involving land disputes arising from the Louisiana and Florida treaties. ${ }^{152}$ Some were private disputes between private parties, ${ }^{153}$ but most were public law disputes between the United States and individuals who asserted titles based on French or Spanish grants. "In the whole of the Louisiana Purchase, there were between 13,000 and 14,000 such claims." Louisiana Purchase covered about seven million acres. ${ }^{155}$ Supreme Court decisions in the Florida cases affected "fifteen million acres . . . covering about one-third of the state." 156 The stakes were high because, during this period, "for all the growth of industry and steady accumulation of capital in other forms, land was the principal form and source of wealth in the country."157

1. The Role of International Law: Litigants in the Louisiana/Florida land cases routinely invoked rights protected by international law. Federal statutes governed the procedural rules, but claimants' substantive rights depended on foreign and international law. In most cases, French or Spanish law determined the validity of the initial land grant. ${ }^{158}$ However, neither French nor Spanish law protected individuals from adverse claims by the federal government. In every case, the individual's substantive rights vis-à-vis the United States depended on treaties and/or customary international law. Under international law, any individual who had a valid claim against the French or Spanish government before the treaty of cession had an equally valid claim against the United States after the change of sovereignty. ${ }^{159}$ Conventional wisdom holds that nineteenth century international law did not protect U.S. citizens from their own government. That view is mistaken. The Louisiana/Florida cases rarely specify the citizenship of claimants, but many of them were undoubtedly U.S. citizens. Moreover, citizenship was irrelevant. Both citizens and non-citizens were protected by the relevant rules of international law.

152 See SWISHER, supra note 136, at 747 (stating that "controversies over land titles in the Louisiana Purchase gave rise to some fifty major cases in the Supreme Court . . From Florida the Supreme Court also decided some fifty cases ....").

${ }^{153}$ See, e.g., Foster v. Neilson, 27 U.S. 253 (1829).

154 CUMmings \& MCFARLAND, supra note 146, at 120. There are no reliable estimates of the number of claims under the Florida treaty, but that treaty probably gave rise to a comparable number of claims.

${ }^{155} I d$., at 120 .

156 SWISHER, supra note 136 , at 747-48.

${ }^{157}$ Id., at 747.

${ }^{158}$ In a few cases, the Court determined that a Spanish grant was invalid because Spain purported to grant land to someone after the U.S. acquired sovereignty. See, e.g., Garcia v. Lee, 37 U.S. 511 (1838). In such cases, the initial grant was invalid not because of Spanish law, but because Spain did not have sovereignty over the property it purported to grant.

${ }^{159}$ See, e.g., United States v. Wiggins, 39 U.S. 334, 350 (1840) ("the United States were bound, after the cession of the country, to the same extent that Spain had been bound before the ratification of the treaty"). 


\section{Polymorphous Public Law Litigation}

The Supreme Court decision in United States v. Arredondo is illustrative. ${ }^{160}$ The grant at issue in Arredondo "covered an area of 289,645 acres . . . It embraced nearly the entire northeastern coast of Florida, including Jacksonville and other cities."161 Former Attorney General William Wirt and Attorney General Roger Taney argued the case for the government. Former Attorney General John Berrien and Daniel Webster represented the private claimants. ${ }^{162}$ "The government attacked the claim as fraudulent, denied the legal power of the Cuban army intendant to make the grant, [and] argued that the lands were within the Indian boundary and not subject to grant." 163 The Supreme Court rejected all these arguments, ruling decisively for the private claimants. The Court emphasized that "[t]he treaty and the acts of Congress were to be liberally construed, [and] the acts of foreign public officers were presumed to be lawful." "164

Later commentators noted that Arredondo "served as the most important legal precedent for the entire body of Louisiana, Florida, and later California land cases." "165 Arredondo established a key legal precedent for protecting property rights from government infringement. However, the Court did not apply constitutional law to protect individuals from government overreaching. Instead, the Court applied international and foreign law to constrain federal executive power. Summarizing the body of precedent derived from Arredondo, the Supreme Court later said, "the claims shall be adjudged, and the equities of the claimants determined and settled according to the law of nations, the stipulations of the treaty, and ... the laws and ordinances of the government from which the claims are alleged to have been derived."166 In short, the Court applied a polymorphous model, drawing on multiple sources of law to resolve individual claims against the government.

Private litigants had great success litigating property claims against the federal government. Between 1832 and 1836, Joseph Mills White, the foremost U.S. expert on Spanish land law, represented private claimants before the Supreme Court in 24 cases involving the Louisiana and Florida treaties. ${ }^{167} \mathrm{He}$ won a partial or total victory in 23 of 24 cases, ${ }^{168}$ relying on international and foreign law to protect individual rights from government encroachment. Few, if any, modern Supreme Court litigators can claim a comparable success rate.

${ }^{160} 31$ U.S. 691 (1832).

${ }^{161} I d$. at 126.

${ }^{162} I d$. at 127 .

${ }^{163} \mathrm{Id}$.

${ }^{164} \mathrm{Id}$.

${ }^{165}$ CUMMINGS \& MCFARLAND, supra note 146, at 127.

${ }^{166}$ United States v. Wiggins, 39 U.S. 334, 350 (1840).

${ }^{167}$ See ERNEST F. DibBLe, JoSEPH MiLls White: ANTI-JACKSONIAN Floridian 173-81 (2003).

${ }^{168}$ See id., at $134,173-81$. 


\section{Polymorphous Public Law Litigation}

2. The Mobile Waterfront Cases: Between 1840 and 1850, the Court decided seven cases involving waterfront property in Mobile, Alabama. ${ }^{169}$ Those cases affected title to "a most valuable portion, and a very large portion, of the second [largest] city on the Gulf of Mexico, in wealth and population."170 They are important doctrinally because the Court held in two cases that certain federal statutes were void. ${ }^{171}$ They are the only two cases in the entire line of Florida, Louisiana, and California land claims where the Court invalidated a federal statute.

The city of Mobile is located in a region that was subject to a territorial dispute between the United States and Spain from 1803 to 1819. Spain claimed the territory as part of Florida. The U.S. claimed that it acquired the land from France in 1803 as part of Louisiana. The dispute was not resolved until the U.S. acquired Florida from Spain in 1819. ${ }^{172}$

Despite U.S. claims of sovereignty, Spain exercised de facto control over Mobile and surrounding areas until about October 1810, when the President "ordered military possession to be taken of the disputed territory." "173 Between 1803 and 1810, Spanish authorities issued numerous land grants in the region. The Supreme Court consistently held that Spanish grants in the disputed territory after 1803 did not convey legal title because Spain did not have de jure sovereignty. ${ }^{174}$ However, the Court held that Spain's de facto control gave it the "power to grant" inchoate titles. ${ }^{175}$ Moreover, the United States had an obligation under customary international law to respect the inchoate property rights of Spanish grantees, ${ }^{176}$ and Congress had power to grant legal titles to individuals who held inchoate rights based on Spanish grants. ${ }^{177}$ Congress "in more than a

${ }^{169}$ Goodtitle ex dem Pollard v. Kibbe, 50 U.S. 471 (1850); Pollard v. Hagan, 44 U.S. 212 (1845); Lessee of Pollard v. Files, 43 U.S. 591 (1844); City of Mobile v. Emanuel, 42 U.S. 95 (1843); City of Mobile v. Hallett, 41 U.S. 261 (1842); City of Mobile v. Eslava, 41 U.S. 234 (1842); Lessee of Pollard's Heirs v. Kibbe, 39 U.S. 353 (1840). The four "Pollard" cases were private disputes; the three "City of Mobile" cases were public law cases. I address all seven cases together because they are all related.

${ }^{170}$ Pollard v. Hagan, 44 U.S. 212, 233 (1845) (Catron, J., dissenting).

${ }^{171}$ Goodtitle ex dem Pollard v. Kibbe, 50 U.S. 471 (1850); Pollard v. Hagan, 44 U.S. 212 (1845).

${ }^{172}$ See Foster v. Neilson, 27 U.S. 253, 300-09 (1829) (explaining the history of the dispute).

${ }^{173}$ Lessee of Pollard's Heirs v. Kibbe, 39 U.S. 353, 370 (1840) (Baldwin, J., concurring).

${ }^{174}$ See Garcia v. Lee, 37 U.S. 511 (1838); Foster v. Neilson, 27 U.S. 253 (1829).

175 See Pollard's Heirs, 39 U.S. 353, 364-66; Lessee of Pollard v. Files, 43 U.S. 591, 602-05 (1844).

${ }^{176}$ See supra notes 143-45 and accompanying text. Some Justices argued that the U.S. also had an obligation under the Florida Treaty. See, e.g., Pollard's Heirs, 39 U.S. 353, 388 (Baldwin, J., concurring). However, the majority held that the U.S. incurred no legal obligations under the Florida Treaty concerning land west of the Perdido River because the U.S. acquired that land from France in 1803. See Lessee of Pollard, 43 U.S. 591, 602.

177 See Pollard's Heirs, 39 U.S. at 365 ("Such claims are certainly not beyond the reach of Congress to confirm, although it may require a special act of Congress for that purpose.") 


\section{Polymorphous Public Law Litigation}

thousand instances respected and confirmed such titles,"178 relying implicitly on this chain of reasoning.

In five of the Mobile waterfront cases, the Court affirmed the validity of land titles based on a combination of Spanish grants and federal legislation. In Lessee of Pollard v. Files ${ }^{179}$ and Lessee of Pollard's Heirs v. Kibbe ${ }^{180}$ the Court affirmed land titles based on: an 1809 Spanish grant to William Pollard; an 1824 federal statute conveying U.S. property rights to the city of Mobile, but preserving the rights of individuals who obtained Spanish grants "during the time at which they [Spain] had the power to grant the same"; ${ }^{181}$ and an 1836 federal statute confirming the title of "the heirs of William Pollard." "I82 In City of Mobile $v$. Emanuel $^{183}$ and City of Mobile v. Hallett, ${ }^{184}$ the Court affirmed the titles of Spanish grantees, but did not cite any federal legislation specifically confirming the validity of those titles. And in City of Mobile v. Eslava, ${ }^{185}$ the Court affirmed the validity of an individual title "acquired by purchase from the United States, at a public sale in 1820 " pursuant to an 1818 federal statute. ${ }^{186}$

However, the Court changed course in its 1845 decision in Pollard v. Hagan. ${ }^{187}$ To understand Hagan, an explanation of the local geography is necessary. ${ }^{188}$ At that time, Water Street ran north-south on the eastern edge of Mobile. The land west of Water Street was dry. During the Spanish occupation, the land east of Water Street was above water at low tide, but under water at high tide. Despite the tidal flow, the Spanish government issued several grants for land east of Water Street. That land remained under water at high tide until 1822 or 1823, when people constructed levees. All the Mobile waterfront cases involved land east of Water Street that was under water at high tide before 1822.

Congressional power was based on Article IV of the Constitution, which grants Congress "Power to dispose of . . . the Territory or other Property belonging to the United States." U.S. Const. art. IV, $\S 3$, cl. 2. If an individual held an inchoate title before the U.S. acquired sovereignty, then the legal title passed to the United States under the treaty, "with the equity attached in the claimant." McDonogh v. Millaudon, 44 U.S. 693, 706 (1845). Property subject to an equitable claim was federal land until the U.S. confirmed the claimant's title. See Sloss, supra note 150, at 151.

${ }^{178}$ Pollard's Heirs, 39 U.S. at 358 (argument of Daniel Webster, plaintiffs' counsel). The number "thousand" refers to land grants in the entire area of the territorial dispute with Spain, not just land in Mobile.

17943 U.S. 591 (1844).

18039 U.S. 353 (1840).

${ }^{181} \mathrm{Id}$., at 362 (quoting Act of May 26, 1824).

${ }^{182} \mathrm{Id}$., at 366 (quoting Act of July 2, 1836).

18342 U.S. 95 (1843).

${ }^{184} 41$ U.S. 261 (1842).

18541 U.S. 234 (1842).

${ }^{186} \mathrm{Id}$. at 243.

18744 U.S. 212 (1845).

${ }^{188}$ The following description is drawn from the cases cited in note 169 supra. 


\section{Polymorphous Public Law Litigation}

Congress admitted Alabama as a State in December 1819. In Pollard v. Hagan, ${ }^{189}$ the Court held that statehood gave Alabama sovereignty over all the "navigable waters, and the soils under them" within the state's territorial limits. ${ }^{190}$ Statehood therefore terminated Congress' power under Article IV of the Constitution to make "Rules and Regulations respecting the Territory or other Property belonging to the United States," 191 insofar as Congress purported to exercise that power over "the shores of navigable waters" inside Alabama. ${ }^{192}$ Since the property at issue was waterfront property, "[ $\mathrm{t}]$ he right of the United States to the public lands, and the power of Congress to make all needful rules and regulations for the sale and disposition thereof, conferred no power to grant to the plaintiffs the land in controversy in this case." ${ }^{193}$ Hence, the federal statutes on which the Court based its holdings in Lessee of Pollard v. Files ${ }^{194}$ and Lessee of Pollard's Heirs v. Kibbe ${ }^{195}$ were void because those statutes, enacted in 1824 and 1836 , purported to confirm or convey title to land that was not subject to federal control after 1819. Similarly, the 1820 land sale that was the basis for the individual's title in City of Mobile v. Eslava ${ }^{196}$ was also presumably void. ${ }^{197}$

The Court reaffirmed Hagan's central holding in Goodtitle ex dem Pollard v. Kibbe ${ }^{198}$ However, thirty years later the Court partially overruled Hagan by holding that the United States can exercise its power of eminent domain within the territorial borders of a State. ${ }^{199}$ Interestingly, the Court relied partly on international law to justify its view of the federal eminent domain power. ${ }^{200}$

3. Comparison to Modern Public Law Cases: The Louisiana/Florida land cases are similar in several respects to modern public law litigation. The land cases involved judicial review of administrative decisions made pursuant to federal statutes creating specialized tribunals (the land commissions). The cases raised generic conflicts between private parties and federal officials whose mission was to safeguard public goods without adversely affecting private rights. Consider an analogy to modern disability cases. In those cases, private claimants

18944 U.S. 212 (1845).

${ }^{190} I d$. at $228-29$.

${ }^{191}$ U.S. Const. art. IV $§ 3$, cl. 2.

19244 U.S., at 230

${ }^{193} \mathrm{Id}$.

19443 U.S. 591 (1844).

19539 U.S. 353 (1840).

19641 U.S. 234 (1842).

${ }^{197}$ By the same logic, numerous federal statutes concerning title to land in Louisiana enacted after Louisiana became a State would also be void, but the Court never pursued this line of reasoning to its logical conclusion.

198 50 U.S. 471 (1850).

${ }^{199}$ Kohl v. United States, 91 U.S. 367 (1875).

${ }^{200}$ See id. at 371-72 (citing Vattel and Bynkershoek for the proposition that the power of eminent domain "is inseparable from sovereignty"). 


\section{Polymorphous Public Law Litigation}

assert an entitlement to public goods (federal dollars). Federal officers have a statutory duty to protect public goods from unworthy claimants and to distribute those goods to worthy claimants. Similarly, in the nineteenth century land cases private claimants asserted an entitlement to public goods (federal lands). Federal officers had a statutory duty to protect those public goods from unworthy claimants, ${ }^{201}$ but they also had a duty (under treaties and customary international law) to confirm the titles of worthy claimants. Thus, the nineteenth century land cases are structurally similar to certain modern administrative law cases.

One surprisingly modern feature of the nineteenth century land cases was the prevalence of "cause lawyering." In the mid-nineteenth century, the Court was ideologically divided between Justices sympathetic to individuals who asserted property rights based on French or Spanish grants, and Justices who favored the federal government's power to distribute land to its chosen grantees. ${ }^{202}$ Joseph Mills White represented individual claimants before the Supreme Court in at least 24 land cases. ${ }^{203}$ Daniel Webster argued several cases on behalf of private claimants, ${ }^{204}$ joining White as co-counsel in two very significant cases. ${ }^{205}$ White represented individual claimants because he was committed to the "Jeffersonian belief . . . in small landholding as the secret to the creation and maintenance of a viable democracy." "206 Similarly, Webster represented individual claimants because he believed, based on "[f]irst principles of justice drawn from natural law," that "government must recognize claims of title to ownership . . . and must assure a large measure of freedom in the uses of property.",207

Modern lawyers might frame property rights claims against the government as Fifth Amendment Takings claims. However, the lawyers who litigated the Louisiana/Florida property cases rarely invoked constitutional law to frame their arguments, ${ }^{208}$ and the Court rarely applied constitutional law to decide

${ }^{201}$ See CUMmings \& MCFARLAND, supra note 146, at 123-24 (noting that Attorney General John Crittenden, during his tenure as Attorney General, succeeded in "saving nearly two million acres for the public domain").

202 See SWISHER, supra note 136, at 748.

203 See DIBBLE, supra note 167 , at 173-81.

${ }^{204}$ See MAURICE G. BAXTER, DANIEL Webster \& THE SuPREME COURT 143-45 (1966).

${ }^{205}$ White and Webster served as co-counsel in Arredondo, discussed above, as well as Mitchel v. United States, 34 U.S. 711 (1835). Mitchel was significant because the Court granted about 1.2 million acres of land to private claimants, the largest single victory (in terms of acreage) for private claimants in any of the Louisiana/Florida land cases.

${ }^{206}$ DIBBLE, supra note 167 , at 159.

207 BAXTER, supra note 204, at 142 .

${ }^{208}$ From the perspective of individual claimants who held inchoate titles based on French or Spanish grants, government efforts to seize their land probably seemed like a taking of private property for public use. From the government's standpoint, there was no Taking because the government actually held legal title to the property after the transfer of sovereignty from France or 


\section{Polymorphous Public Law Litigation}

David Sloss, Draft, January 2014

the cases. In the pre-Civil War era, a constitutional claim challenging a governmental taking of private property would probably have failed because key legal precedents supported the government's power to seize private property without paying compensation. ${ }^{209}$ Regardless, claimants did not need constitutional law to protect their rights from government infringement because the courts protected their rights through vigorous enforcement of international law.

\section{Chinese Habeas Litigation}

Between 1882 and 1905, Chinese petitioners seeking admission into the United States filed thousands of habeas corpus petitions in federal courts. ${ }^{210}$ Despite restrictive immigration laws designed to exclude Chinese immigrants, petitioners won a very high proportion of those cases. Judicial decisions relied primarily on international law, not constitutional law, to support the entry rights of Chinese petitioners. The Supreme Court did not invalidate any federal law restricting Chinese immigration during this period. ${ }^{211}$ Thus, the analysis shows that courts can provide robust protection for individual rights in a manner consistent with principles of popular sovereignty by applying international law to constrain government power and protect individual rights. The following narrative is divided into three time periods: 1868-88, 1888-94, and 1894-1905.

1. Period One - 1868-1888: China and the United States concluded the Burlingame Treaty in $1868 .^{212}$ Evoking natural law, the treaty affirmed the "inherent and inalienable right of man to change his home." ${ }^{213}$ Both countries promised to allow "free migration and emigration of their citizens and subjects, respectively, from the one country to the other, for purposes of curiosity, of trade, or as permanent residents." 214 By 1880, more than 100,000 Chinese nationals were living in the United States. ${ }^{215}$ The influx of immigrants produced a political backlash, resulting in a wave of anti-Chinese legislation. Responding to political

Spain. See supra note 177 . However, that view was contestable. Lawyers could reasonably have presented the claims as Fifth Amendment Takings claims.

209 See DANIEL W. HAMilton, The Limits OF SOVEREIGNTY: PROPERTy CONFISCATION IN THE UNION AND THE CONFEDERACY DURING THE CIVIL WAR 1-4 (2007).

${ }^{210}$ This section focuses solely on "exclusion" cases, where the government sought to prevent Chinese persons from entering the United States. It does not address "deportation" cases, where the government sought to remove someone who had entered previously.

${ }^{211}$ The Court did invalidate some state laws that discriminated against Chinese residents. See, e.g., Yick Wo v. Hopkins, 118 U.S. 356 (1886). And in Wong Wing v. United States, 163 U.S. 228 (1896), the Court invalidated a federal statute subjecting Chinese persons to criminal penalties without granting them Fifth or Sixth Amendment jury rights.

${ }^{212}$ Burlingame Treaty, U.S.-China, July 28, 1868, 16 Stat. 739.

${ }^{213}$ Id., art. V.

${ }^{214} I d$.

215 See Lucy E. SAlyer, LAws Harsh AS Tigers: Chinese IMMigrants AND THE Shaping OF MODERN IMMIGRATION LAW 7-8 (1995). 


\section{Polymorphous Public Law Litigation}

David Sloss, Draft, January 2014

pressure to restrict Chinese immigration, President Hayes appointed a commission to renegotiate the treaty with China. ${ }^{216}$

The new treaty, concluded in 1880 , allowed the United States to restrict, but not prohibit, immigration of Chinese laborers " $[\mathrm{w}]$ henever in the opinion of the Government of the United States, the coming of Chinese laborers to the United States, or their residence therein, affects or threatens to affect the interests of that country, or to endanger the good order of the said country . . . ."217 Although the treaty permitted restrictions on immigration of Chinese laborers, "[t]he limitation ... shall apply only to Chinese who may go to the United States as laborers, other classes not being included in the limitations." ${ }^{218}$ The treaty provided that "teachers, students, [and] merchants," as well as laborers who resided in the United States before entry into force of the treaty, "shall be allowed to go and come of their own free will and accord." 219 Thus, the new treaty attempted to balance the populist desire to exclude Chinese immigrants with the natural law commitment to the "inherent and inalienable right of man to change his home." $" 220$

After conclusion of the 1880 treaty, Congress enacted the Chinese Exclusion Act of 1882, suspending immigration of Chinese laborers for ten years, as permitted by the treaty. ${ }^{221}$ The Act gave primary enforcement responsibility to customs collectors at ports of entry. ${ }^{222}$ The collector in San Francisco "adopted a very strict reading of the act" and denied entry to numerous prospective immigrants. $^{223}$ The Chinese responded by filing habeas petitions in the Northern District of California. The federal court adopted a more expansive view of Chinese entry rights than the customs collector. Consequently, "[w]ithin fourteen months of the act's passage ... the federal courts were directly or indirectly responsible for the entry of one-third of all Chinese landed during that period."224 Judicial decisions granting habeas petitions invoked treaties with China as the primary source of rights for Chinese immigrants. ${ }^{225}$

${ }^{216} I d$., at $12-14$.

${ }^{217}$ Treaty Concerning Immigration, U.S.-China, art. I, Nov. 17, 1880, 22 Stat. 826.

${ }^{218} \mathrm{Id}$.

${ }^{219} \mathrm{Id}$., art. II.

${ }^{220}$ Burlingame Treaty, supra note 212 , art. V.

${ }^{221}$ Act of May 6, 1882, 22 Stat. 58.

${ }^{222}$ See id., sec. 9.

${ }^{223}$ SALYER, supra note 215, at 18.

${ }^{224}$ Id., at 19 (citing Hudson N. Janisch, "The Chinese, the Courts, and the Constitution: A Study of the Legal Issues Raised by Chinese Immigration, 1850-1902 (1971)).

${ }^{225}$ See, e.g., In re Chin A On, 18 F. 506, 507 (D.C. Cal. 1883) ("before we can impute to congress an intention to violate an important article of a treaty with a foreign power, that intention must be clearly and unequivocally manifested, and the language of the law, which is supposed to constitute the violation, must admit of no other reasonable construction"); Case of the Chinese Merchant, 13 F. 605 (C.C. Cal. 1882) ("we will not assume, in the absence of plain language to the contrary, 


\section{Polymorphous Public Law Litigation}

In 1884, Congress amended the Chinese Exclusion Act to create additional hurdles for prospective immigrants. ${ }^{226}$ Under the 1880 treaty and the 1882 statute, Chinese laborers who lived in the United States before passage of the 1882 Act retained the right to exit and return. Not surprisingly, customs collectors had difficulty distinguishing between Chinese who actually resided in the U.S. before 1882, and those who falsely claimed prior residence to gain entry. ${ }^{227}$ The 1882 Act addressed this problem by allowing Chinese laborers to obtain a certificate before leaving the country. ${ }^{228}$ The certificate entitled Chinese laborers to "re-enter the United States upon producing and delivering the same to the collector of customs." 229 The 1884 Amendment tightened the rules by providing that "said certificate shall be the only evidence permissible to establish his right of reentry." 230

Despite the clear statutory mandate, the Supreme Court soon decided two cases holding that "said certificate" was not the only evidence permissible to establish a right of entry. In Chew Heong v. United States, ${ }^{231}$ the Court held that a Chinese laborer who resided in the U.S. before passage of the 1882 Act, left the country without a certificate before enactment of the 1884 Amendment, and then sought re-entry after passage of the 1884 Amendment, was entitled to enter the country without a certificate. The Court stated: "[S]ince the purpose avowed in the act was to faithfully execute the treaty, any interpretation of its provisions would be rejected which imputes to congress an intention to disregard the plighted faith of the government, and, consequently, the court ought, if possible, to adopt that construction which recognized and saved rights secured by the treaty."232 Similarly, in United States v. Jung Ah Lung, ${ }^{233}$ the Court held that a Chinese laborer who claimed that his certificate was stolen was entitled to re-enter if he could prove prior residence by other means.

Between passage of the Chinese Exclusion Act in 1882 and passage of the Scott Act in 1888 (discussed below), federal courts consistently adopted a more generous view of Chinese entry rights than the customs collector in San Francisco. By 1888, "4091 Chinese had petitioned the federal courts for a hearing." The courts granted petitioners entry rights in 85 percent of Chinese

that congress intended to disregard the obligations of the original treaty of 1868 , which remains in full force except as modified by the supplementary treaty of 1880 ").

${ }^{226}$ Act of July 5, 1884, 23 Stat. 115.

${ }^{227}$ Most of the officials responsible for enforcing the Chinese Exclusion Act "shared the belief ... that the Chinese and their witnesses lied to gain entry." SALYER, supra note 215, at 76.

${ }^{228}$ Act of May 6, 1882, 22 Stat. 58, sec. 4.

${ }^{229} \mathrm{Id}$.

${ }^{230}$ Act of July 5, 1884, 23 Stat. 115, sec. 4 (emphasis added).

${ }^{231} 112$ U.S. 536 (1884).

${ }^{232} I d$., at 549.

${ }^{233} 124$ U.S. 621 (1888). 


\section{Polymorphous Public Law Litigation}

David Sloss, Draft, January 2014

habeas cases. ${ }^{234}$ Although the Chinese Exclusion Act was clearly intended to restrict immigration, the courts construed the Act broadly to protect the treatybased entry rights of Chinese immigrants. Courts justified their decisions by invoking the principle that statutes should be construed in conformity with U.S. treaty obligations. ${ }^{235}$ In sum, the courts provided robust protection for Chinese entry rights without applying constitutional law and without invalidating any federal legislation governing Chinese immigration.

2. Period Two - 1888-1894: Congress enacted the Scott Act in 1888 . $^{236}$ The 1882 and 1884 Acts could plausibly be construed consistently with the 1880 treaty. In the Scott Act, though, Congress made unmistakably clear that it did not intend to comply with the treaty. Although the treaty guaranteed Chinese laborers who resided in the United States before 1880 the right to "go and come of their own free will," 237 the Scott Act provided that "it shall be unlawful for any Chinese laborer who shall at any time heretofore have been . . . a resident within the United States, and who shall have departed, or shall depart, therefrom, and shall not have returned before the passage of this act, to return to . . . the United States." 238 To avert any possible misinterpretation, Congress added that "every certificate heretofore issued . . . is hereby declared void . . . and the Chinese laborer claiming admission by virtue thereof shall not be permitted to enter the United States."239

In Chae Chan Ping v. United States, ${ }^{240}$ a Chinese laborer who held a certificate under the 1884 Act tried to enter the country. ${ }^{241}$ The customs collector denied him entry in reliance on the Scott Act because the Act declared the certificate void. ${ }^{242}$ Chae Chan Ping challenged the constitutionality of the Act, arguing that it constituted an illegal "expulsion from the country of Chinese laborers, in violation of existing treaties between the United States and the government of China, and of rights vested in them under the laws of Congress." 243 The Supreme Court upheld the Act. The Court acknowledged that the Act contravened "express stipulations of the treaty of 1868, and of the supplemental treaty of 1880." ${ }^{244}$ Nevertheless, the Court ruled that "the last expression of the

\footnotetext{
${ }^{234}$ SALYER, supra note 215 , at 20.

${ }^{235}$ See supra notes 225, 232, and accompanying text; see also In re Tung Yeong, 19 F. 184, 185 (D.C. Cal. 1884).

${ }^{236}$ Scott Act, Oct. 1, 1888, 25 Stat. 504.

${ }^{237}$ Treaty Concerning Immigration, U.S.-China, art. II, Nov. 17, 1880, 22 Stat. 826.

${ }^{238}$ Scott Act, Oct. 1, 1888, 25 Stat. 504, sec. 1.

${ }^{239}$ Id., sec. 2.

240130 U.S. 581 (1889).

${ }^{241} \mathrm{Id}$., at 582 .

${ }^{242} \mathrm{Id}$.

${ }^{243} \mathrm{Id}$., at 589 .

${ }^{244} I d$., at 600 .
} 


\section{Polymorphous Public Law Litigation}

sovereign will must control."245 The Court's opinion is replete with language affirming the principle that courts must give judicial effect to statutes enacted by democratic legislatures.

After Chae Chan Ping, Chinese nationals could no longer enter the country as laborers. Nevertheless, Chinese immigrants continued to litigate habeas petitions with great success by claiming a right to enter the country as merchants, ${ }^{246}$ U.S. citizens, ${ }^{247}$ or the wives or children of merchants or citizens. ${ }^{248}$ In December 1890, a customs inspector testified that, between passage of the Scott Act and November 30, 1890, the federal court in San Francisco granted almost two thousand habeas petitions filed by Chinese immigrants, but denied only 157 petitions. $^{249}$ Thus, Chinese petitioners won almost $93 \%$ of the habeas petitions filed within the first 26 months after passage of the Scott Act. Overall, between 1882 and 1891, "the Chinese filed more than seven thousand petitions for habeas corpus, and the court attracted the wrath of the public and the administrative officials by allowing the vast majority of these Chinese to enter freely.",250

Congress enacted a new immigration law in $1891 .^{251}$ The 1891 Act barred judicial review of administrative decisions denying entry to non-citizens. ${ }^{252}$ However, the prohibition of judicial review did not apply to Chinese immigrants. ${ }^{253}$ Consequently, federal courts continued to grant Chinese habeas petitions. Professor Salyer determined that the federal district court in San Francisco granted Chinese habeas petitions at an annual rate of $73 \%$ in $1891,88 \%$ in $1892,66 \%$ in 1893 , and $80 \%$ in $1894 .^{254}$

Lau Ow Bew v. United States ${ }^{255}$ illustrates the types of cases litigated in the early 1890s. Petitioner had lived in the United States for seventeen years. During that time he was "engaged in the wholesale and importing mercantile

${ }^{245} I d$.

246 See, e.g., Lau Ow Bew v. United States, 144 U.S. 47 (1892) (granting entry to Chinese merchant).

247 See, e.g., United States v. Wong Kim Ark, 169 U.S. 649 (1898) (granting entry to a person of Chinese descent who was a U.S. citizen).

248 See, e.g., United States v. Gue Lim, 176 U.S. 459 (1900) (ruling in favor of the wife of a Chinese merchant).

${ }^{249}$ U.S. Congress, Select Committee on Immigration and Naturalization, Chinese Immigration, $51^{\text {st }}$ Cong., 2d Sess., 272-73 (testimony of S. J. Ruddell).

${ }^{250}$ SALYER, supra note 215 , at 33.

251 Act of March 3, 1891, 26 Stat. 1084.

${ }^{252}$ See Nishimura Ekiu v. United States, 142 U.S. 651 (1892).

253 See SALYER, supra note 215, at 26-32.

${ }^{254}$ See id., at 80 . These figures apply only to exclusion cases, not deportation cases.

255144 U.S. 47 (1892). 


\section{Polymorphous Public Law Litigation}

business in the city of Portland," Oregon. ${ }^{256}$ He departed the country in September 1890 to visit relatives in China, returning in August 1891. When he returned he produced documents to show he was a merchant. As a merchant, the treaties protected his right to enter the country. The customs collector denied entry, ${ }^{257}$ invoking a statute requiring Chinese merchants to "obtain the permission of . . . the Chinese Government . . . in each case to be evidenced by a certificate issued by such Government."258

Chief Justice Fuller asked: "Does the section apply to Chinese merchants, already domiciled in the United States, who, having left the country for temporary purposes . . . seek to re-enter it on their return to their business and their homes?"259 The Court concluded it was absurd to require a merchant who had lived in the U.S. for seventeen years to obtain a certificate from the Chinese government granting him permission to return to the country. ${ }^{260}$ Fuller applied standard principles of statutory interpretation to support this conclusion. He also invoked petitioner's rights under "general international law" and the treaties with China. ${ }^{261}$ Finally, he quoted the Court's prior decision in Chew Heong: "since the purpose avowed in the [Chinese Exclusion] act was to faithfully execute the treaty, any interpretation of its provisions would be rejected which imputed to congress an intention to disregard the plighted faith of the government; and, consequently, the court ought, if possible, to adopt that construction which recognized and saved rights secured by the treaty."262

In sum, federal courts applied a combination of statutes and treaties to provide judicial protection for the treaty-based rights of Chinese immigrants. ${ }^{263}$ By applying statutes and treaties, rather than constitutional law, ${ }^{264}$ the courts preserved Congress' prerogative to modify the governing legal rules. Thus, Chinese habeas litigation provides an example of polymorphous public law litigation that combines robust judicial protection for individual rights with genuine judicial respect for popular sovereignty.

${ }^{256}$ Lau Ow Bew, 144 U.S. at 48.

${ }^{257}$ Id., at 48-49.

${ }^{258}$ Act of July 5, 1884, sec. 6, 23 Stat. 115, 116.

${ }^{259}$ Lau Ow Bew, 144 U.S., at 59.

${ }^{260}$ Id., at 59-61.

${ }^{261} I d$., at 61-62.

${ }^{262}$ Id., at 62 (quoting Chew Heong, 112 U.S. at 549).

${ }^{263}$ Non-Chinese immigrants did not fare as well because the 1891 Act barred judicial review of administrative decisions in those cases. See Nishimura Ekiu v. United States, 142 U.S. 651 (1892).

264 During this period the Court frequently invoked international law in the context of constitutional interpretation to support an expansive view of government power that limited protection for individual rights. In contrast, the Court used international law in statutory interpretation to constrain government power and protect individual rights. See Lee and Sloss, supra note 18. 


\section{Polymorphous Public Law Litigation}

3. Period Three - 1894-1905: In 1894 the United States and China concluded a new treaty prohibiting entry of Chinese laborers into the United States "for a period of ten years." "265 The treaty reaffirmed that "[ $\mathrm{t}]$ he provisions of this Convention shall not affect the right ... of Chinese subjects, being officials, teachers, students, merchants or travellers for curiosity or pleasure, but not laborers, of coming to the United States and residing therein."266 Thus, as before, the 1894 treaty balanced the populist desire to exclude Chinese laborers with the natural law commitment to the "inherent and inalienable right of man to change his home."267

Meanwhile, the public was concerned that Chinese petitioners repeatedly used habeas corpus to overturn administrative decisions denying them admission. ${ }^{268}$ Accordingly, in August 1894 Congress enacted an amendment barring judicial review of exclusion decisions. The statute provided: "In every case where an alien is excluded from admission into the United States . . . the decision of the appropriate immigration or customs officers, if adverse to the admission of such alien, shall be final, unless reversed on appeal to the Secretary of the Treasury." 269 Thus, the statute extended to Chinese immigrants the bar on judicial review that previously applied to other non-citizens under the 1891 Act.

In Lem Moon Sing v. United States, ${ }^{270}$ a Chinese merchant with a "permanent domicile" in the U.S. filed a petition challenging the customs officer's decision denying him admission when he returned home after a temporary business trip to China. ${ }^{271}$ The Supreme Court affirmed the lower court decision denying habeas relief, saying that the 1894 Act precluded judicial review of the customs officer's decision. ${ }^{272}$ The Court relied on its prior decision in Nishimura Ekiu, ${ }^{273}$ which upheld the validity of the 1891 statute barring judicial review of administrative decisions in non-Chinese cases. Justice Harlan, writing for the majority in Lem Moon Sing, said there was no principled basis for distinguishing between the 1891 statute at issue in Nishimura Ekiu and the 1894 statute at issue in Lem Moon Sing. ${ }^{274}$

Respectfully, the Court's decision in Lem Moon Sing was mistaken. Lem Moon Sing and Nishimura Ekiu are readily distinguishable. In Nishimura Ekiu,

${ }^{265}$ Convention on Immigration, U.S.-China, art. I, March 17, 1894, 28 Stat. 1210.

${ }^{266} I d$., art. III.

${ }^{267}$ Burlingame Treaty, supra note 212, art. V.

${ }^{268}$ See SALYER, supra note 215, at 96-97.

${ }^{269}$ Act of August 18, 1894, 28 Stat. 390.

${ }^{270} 158$ U.S. 538 (1895).

${ }^{271} \mathrm{Id}$., at 539-40.

${ }^{272}$ See id., at 540-49.

${ }^{273}$ Nishimura Ekiu v. United States, 142 U.S. 651 (1892).

${ }^{274}$ See Lem Moon Sing, 158 U.S. at 541-47. 


\section{Polymorphous Public Law Litigation}

the petitioner was "a person without means of support, without relatives or friends in the United States . . . unable to care for herself, and liable to become a public charge." She was therefore ineligible to enter under the 1891 statute. ${ }^{275}$ In contrast, Lem Moon Sing was a Chinese merchant with a permanent domicile in the United States who - based on the facts in the Supreme Court opinion - had a clear right to enter under the 1894 treaty. The Court's opinion in Lem Moon Sing provides no indication of any statutory basis for the customs officer's decision to deny entry; his decision may have been entirely arbitrary and capricious. Even so, said Justice Harlan, the 1894 statute barred judicial review by way of habeas corpus. That conclusion is troubling. The Court could easily have held that Congress did not intend to bar judicial review in cases where the immigration inspector's decision was arbitrary, capricious or contrary to clearly established law. ${ }^{276}$

Lem Moon Sing appeared finally to bar judicial review of habeas petitions in Chinese exclusion cases. However, the courts continued to entertain habeas petitions from people of Chinese descent who claimed to be U.S. citizens. In United States v. Wong Kim Ark, ${ }^{277}$ the Court held that "a child born in the United States, of parents of Chinese descent, who at the time of his birth . . . have a permanent domicile and residence in the United States . . . becomes at the time of his birth a citizen of the United States, by virtue of" the Fourteenth Amendment. ${ }^{278}$ Since the 1894 statute merely barred judicial review in cases "where an alien is excluded from admission," 279 persons of Chinese descent who claimed birthright citizenship under the Fourteenth Amendment could still obtain judicial review.

Surprisingly, federal courts continued to grant habeas relief in most cases. Between 1895 (when Lem Moon Sing was decided) and 1904, the Northern District of California entertained 1559 habeas petitions filed by persons of Chinese descent who sought admission to the country. The court granted relief in about $55 \%$ of those cases. ${ }^{280}$ Chinese habeas litigation finally ended in 1905 when the Supreme Court ruled in United States v. Ju Toy that federal courts lacked

\footnotetext{
${ }^{275}$ Nishimura Ekiu, 12 S.Ct. at 337-38.

276 The Court's opinion in Lem Moon Sing presents the issues as if there is a stark choice between de novo review or zero review, with no possible middle ground. See Lem Moon Sing, 158 U.S. at 546-47. In this respect, the Court's opinion is at odds with modern administrative law, which recognizes various circumstances where deferential judicial review is appropriate.

277 169 U.S. 649 (1898).

${ }^{278}$ Id., at 653. The Fourteenth Amendment specifies: "All persons born . . . in the United States, and subject to the jurisdiction thereof, are citizens of the United States."

${ }^{279}$ Act of August 18, 1894, 28 Stat. 390 (emphasis added).

${ }^{280}$ This figure is based on Table 3 on page 80 of SALYER, supra note 215.
} 


\section{Polymorphous Public Law Litigation}

David Sloss, Draft, January 2014

jurisdiction to entertain habeas petitions filed by persons of Chinese descent who claimed birthright citizenship under the Fourteenth Amendment. ${ }^{281}$

One can legitimately criticize the decisions in Lem Moon Sing and Ju Toy on the grounds that the Court caved too quickly to legislative efforts to bar judicial review of administrative decisions. The Court could potentially have done more to preserve limited judicial review without invalidating statutes approved by Congress. Still, the overall record of federal court decisions between 1882 and 1905 reveals a federal judiciary that was committed to both individual rights and popular sovereignty, and that did a creditable job mitigating the tension between those competing goals.

\section{Summary}

The preceding case studies illustrate several points about nineteenth century public law litigation. In both the Chinese cases and the Louisiana/Florida cases, federal courts relied on international law, not constitutional law, to protect individual rights from government infringement. The empirical analysis above shows that judicial reliance on international law was a characteristic feature of nineteenth century public law litigation.

The rights at issue in both the Chinese cases and the Louisiana/Florida cases could reasonably be characterized as "fundamental" rights. The Burlingame Treaty affirmed the "inherent and inalienable right of man to change his home."282 John Marshall stated: "that sense of justice and of right which is acknowledged and felt by the whole civilized world would be outraged, if private property should be generally confiscated, and private rights annulled" when territory is transferred between sovereigns. ${ }^{283}$ Although many nineteenth century lawyers conceived the rights at issue as "fundamental," they did not constitutionalize those rights. The Court could have invoked the Fifth Amendment Takings Clause to protect property rights in Louisiana and Florida. ${ }^{284}$ It could reasonably have invoked the liberty component of the Fifth Amendment Due Process Clause to protect the "inalienable right of man to change his home." 285 Instead, the courts relied on international law, not constitutional law, to protect fundamental rights.

\footnotetext{
281198 U.S. 253 (1905). The Court left an opening for petitioners who alleged abuse of authority by administrative officers.

${ }^{282}$ Burlingame Treaty, supra note 212, art. V.

${ }^{283}$ United States v. Percheman, 32 U.S. 51, 87 (1833).

${ }^{284}$ See supra note 208.

285 Indeed, the right to freedom of movement is arguably a stronger candidate for substantive protection under the Due Process Clause than the right not to be sued in an out-of-state court, which the Supreme Court constitutionalized after Pennoyer. See supra notes 7-18 and accompanying text.
} 


\section{Polymorphous Public Law Litigation}

The choice to rely on international law, rather than constitutional law, did not undermine judicial protection for individual rights. The property owners in the Louisiana/Florida cases and the Chinese immigrants in the habeas cases had remarkably successful litigation records. ${ }^{286}$ Indeed, it would be difficult to identify any area of modern constitutional litigation where groups have achieved a higher winning percentage litigating claims against the federal government.

Finally, nineteenth century public law litigation was broadly consistent with principles of popular sovereignty. Although the Supreme Court frequently ruled against the federal government in the Louisiana/Florida cases and the Chinese cases, the Court rarely invalidated a federal statute. ${ }^{287}$ Moreover, the Court typically framed its decisions in ways that avoided placing significant restrictions on Congress' future legislative options. In contrast, the modern Supreme Court often issues constitutional decisions invalidating federal statutes, ${ }^{288}$ and frames its decisions in ways that impose significant restrictions on Congress' future legislative options. ${ }^{289}$ Hence, the shift from a polymorphous model of public law litigation in the nineteenth century to a constitutionalized model in the twentieth century exacerbated the tension between judicial review and popular sovereignty.

IV

\section{Reviving the Polymorphous Model of Public Law Litigation}

Given that nineteenth century federal courts applied a polymorphous model of public law litigation, is it feasible or desirable to revive that model in the twenty-first century? The primary argument in favor of revival can be summarized as follows. Judicial review is essential to protect individual rights. Popular sovereignty is essential to preserve "government of the people, by the people, [and] for the people." 290 Our current constitutionalized system of public law litigation sets up a stark choice: either we sacrifice individual rights for popular sovereignty, or we sacrifice democratic self-government for the sake of

\footnotetext{
${ }^{286}$ See supra notes 160-68, 234-35, 249-54, 277-81, and accompanying text.

${ }^{287}$ With respect to Chinese cases, see supra note 211 . With respect to the Louisiana/Florida cases, see supra notes 169-71 and 189-200 and accompanying text.

${ }^{288}$ See, e.g., Nat'l Fed. of Ind. Business v. Sebelius, 132 S.Ct. 2566 (2012) (invalidating portions of the Patient Protection and Affordable Care Act); United States v. Morrison, 529 U.S. 598 (2000) (invalidating portions of the Violence Against Women Act); City of Boerne v. Flores, 521 U.S. 507 (1997) (invalidating portions of the Religious Freedom Restoration Act).

${ }^{289}$ See, e.g., Nat'l Fed. of Ind. Business v. Sebelius, 132 S.Ct. 2566 (2012) (restricting the scope of Congress' legislative power under the Spending Clause); City of Boerne v. Flores, 521 U.S. 507 (1997) (restricting the scope of Congress' legislative power under Section 5 of the Fourteenth Amendment); United States v. Lopez, 514 U.S. 549 (1995) (restricting the scope of Congress' legislative power under the Commerce Clause).

290 Abraham Lincoln, Address at Gettysburg, Pennsylvania (Nov. 19, 1863), in ABRAHAM LINCOLN, SPEECHES AND WRITINGS, 1859-1865, at 536 (Don E. Fehrenbacher ed., 1989).
} 


\section{Polymorphous Public Law Litigation}

individual rights. Since neither option is attractive, it makes sense to identify a middle way. The polymorphous model provides a middle way. By reviving that model, we can mitigate the tension between individual rights and popular sovereignty.

Part Four addresses application of the polymorphous model in the modern world. The analysis is divided into three sections. The first section shows that international human rights treaties could function as a partial substitute for modern constitutional law. The next section discusses three examples to illustrate the practical application of the polymorphous model. The final section addresses several objections to the project of a twenty-first century revival of the polymorphous model.

\section{A. International Human Rights Treaties as a Partial Substitute for Constitutional Law}

Nineteenth century federal courts applied a combination of treaties, customary international law, common law, statutes and constitutional law to protect individual rights from government infringement. During the twentieth century, treaties, customary international law and common law largely disappeared from the menu of options, leaving statutes and constitutional law as the primary tools for courts to apply as constraints on government action. In theory, advocates of a polymorphous model could attempt to revive older traditions involving judicial application of common law or customary international law. However, both types of law present difficulties. Revival of a nineteenth century common law tradition would require the Supreme Court to overrule or reinterpret its decision in Erie Railroad Co. v. Tompkins. ${ }^{291}$ Even if the Court was willing to do so, common law provides a poor substitute for modern constitutional law because there is limited overlap between the rights protected by constitutional law and the rights protected by common law. ${ }^{292}$

Customary international law (CIL) may appear to be a better fit because CIL incorporates some modern international human rights law, ${ }^{293}$ and there is substantial overlap between human rights law and constitutional law. However, the extent to which CIL incorporates international human rights law is sharply contested. ${ }^{294}$ Moreover, the process for incorporating CIL into domestic law is

\footnotetext{
291304 U.S. 64 (1938).

${ }^{292}$ There is some overlap between common law and constitutional law. For example, in Wise $v$. Withers, 3 U.S. (3 Cranch) 331 (1806), the plaintiff brought a trespass action against a federal officer who searched his home without a warrant. Modern courts would frame the case as a Fourth Amendment violation, but Chief Justice Marshall analysed it as a trespass case.

${ }^{293}$ See RESTATEMENT THIRD, supra note $6, \S 702$.

${ }^{294}$ See, e.g., J. Patrick Kelly, The Twilight of Customary International Law, 40 VA. J. INT’L L. 449 (2000).
} 


\section{Polymorphous Public Law Litigation}

generally less democratic than the process for incorporating treaties. ${ }^{295}$ Since the main purpose of reviving the polymorphous model is to mitigate tension between judicial review and popular sovereignty, it makes sense to focus on law that has been incorporated into domestic law through a democratic process. Therefore, Part Four focuses on international human rights treaties as a partial substitute for constitutional law. ${ }^{296}$ It bears emphasis, though, that this article's emphasis on human rights treaties is not intended to disparage judicial reliance on common law, CIL, or non-human-rights treaties as part of a broader effort to revive a polymorphous model. $^{297}$

The rights protected by human rights treaties are broadly similar to the rights protected by federal constitutional law. The First Amendment protects freedom of religion; ${ }^{298}$ so does Article 18 of the International Covenant on Civil and Political Rights (ICCPR). ${ }^{299}$ The Fourth Amendment restricts government interference with "persons, houses, papers, and effects." 300 Similarly, Article 17 of the ICCPR restricts government interference with "privacy, family, home or correspondence." ${ }^{301}$ The Fifth Amendment prohibits compelled confessions, ${ }^{302}$ as does Article 14(3) $(\mathrm{g})$ of the ICCPR. The Sixth Amendment guarantees a right to counsel, ${ }^{303}$ as do Articles 14(3)(b) and (d) of the ICCPR. The Eighth Amendment prohibits "cruel and unusual punishments." 304 Similarly, Article 7 of the ICCPR and Article 16 of the Torture Convention prohibit "cruel, inhuman or degrading treatment or punishment." 305 The Fourteenth Amendment Equal Protection Clause

\footnotetext{
295 See supra notes 46-53 and accompanying text.

296 One could argue that human rights treaties ratified by the United States have not been incorporated into U.S. law because we ratified the treaties subject to non-self-executing declarations. That argument has some merit. However, the better view is that human rights treaties ratified by the United States are part of the corpus of federal law, notwithstanding the non-selfexecuting declarations. See David Sloss, The Domestication of International Human Rights: NonSelf-Executing Declarations and Human Rights Treaties, 24 YALE J. INT'L L. 129, 144-71 (1999).

${ }^{297}$ Human rights law is not the only body of international law with rights protection similar to federal constitutional law. For example, international rules on expropriation provide protection for private property similar to the Fifth Amendment Takings Clause. See Vicki Been \& Joel C. Beauvais, The Global Fifth Amendment? NAFTA's Investment Protections and the Misguided Quest for an International Regulatory Takings Doctrine, 78 N.Y.U. L. Rev. 30 (2003).

${ }_{298}$ U.S. Const. amend. I.

299 International Covenant on Civil and Political Rights, Dec. 16, 1966, 999 U.N.T.S. 171 [hereinafter ICCPR].

${ }^{300}$ U.S. Const. amend. IV.

${ }^{301}$ ICCPR, supra note 299, art. 17.

${ }^{302}$ U.S. Const. amend. V.

${ }^{303}$ U.S. Const. amend. VI.

${ }^{304}$ U.S. Const. amend. VIII.

305 See ICCPR, supra note 299, art. 7; Convention Against Torture and Other Cruel, Inhuman or Degrading Treatment or Punishment, Feb. 4, 1985, 1465 U.N.T.S. 85 [hereinafter Torture Convention].
} 


\section{Polymorphous Public Law Litigation}

prohibits discrimination on the basis of race or gender, ${ }^{306}$ as do Article 26 of the ICCPR, Article 2 of CERD (for racial discrimination), ${ }^{307}$ and Article 2 of CEDAW (for gender discrimination). ${ }^{308}$

Despite the substantive overlap, international human rights law does not provide a complete substitute for federal constitutional law. Much of the Supreme Court's constitutional doctrine involves federalism and separation of powers issues. International law has little to say about the appropriate distribution of power between federal and state governments, or among the branches of the federal government. ${ }^{309}$ Therefore, under a polymorphous model, federalism and separation of powers issues would presumably be litigated as constitutional claims, not international claims.

Similarly, some individual rights claims would continue to be litigated as constitutional claims because federal constitutional law provides stronger protection for certain rights than does international law. For example, the Court has held that the Second Amendment protects an individual right to keep a gun in one's home for self-defense. ${ }^{310}$ There is no international law analogue to the Second Amendment right to bear arms. Additionally, the Court has construed the First Amendment Free Speech Clause to limit the power of state and federal governments to regulate campaign finance. ${ }^{311}$ International human rights law does protect freedom of expression, ${ }^{312}$ but judicial review of campaign finance laws under an international human rights standard would likely be more deferential than the Supreme Court's First Amendment jurisprudence. ${ }^{313}$

\footnotetext{
306 See generally ERWIN CHEMERINSKY, CONSTITUTIONAL LAW: PRINCIPLES AND POLICIES 663738 (2d ed. 2002).

${ }^{307}$ International Convention on the Elimination of All Forms of Racial Discrimination, Mar. 7, 1966, 660 U.N.T.S. 195 [hereinafter CERD].

${ }^{308}$ Convention on the Elimination of All Forms of Discrimination Against Women, Dec. 18, 1979, 1249 U.N.T.S. 13 [hereinafter CEDAW]. The United States is not a party to CEDAW. However, the U.S. is a party to the ICCPR, the Torture Convention, and the CERD.

${ }^{309}$ Individual Justices have cited foreign law, not international law, to shed light on constitutional federalism issues. See, e.g., Printz v. United States, 521 U.S. 898, 976-77 (1997) (Breyer, J., dissenting). Whereas a comparative constitutional analysis may be helpful in examining certain federalism issues, I am not aware of any international legal rules that are especially helpful in this regard.

${ }^{310}$ See McDonald v. City of Chicago, 130 S.Ct. 3020 (2010); District of Columbia v. Heller, 554 U.S. 570 (2008).

${ }^{311}$ See, e.g., Citizens United v. Federal Election Comm'n, 130 S.Ct. 876 (2010).

${ }^{312}$ See ICCPR, supra note 299, art. 19.

313 See generally Wayne Batchis, Reconciling Campaign Finance Reform with the First Amendment: Looking Both Inside and Outside America's Borders, 25 Quinnipiac L. Rev. 27, 6272 (2006).
} 


\section{Polymorphous Public Law Litigation}

David Sloss, Draft, January 2014

In sum, international human rights law could provide a partial substitute, but not a complete substitute, for federal constitutional law. If Congress authorized federal courts to apply international human rights treaties, or if judges did so without express congressional authorization, the courts could protect many rights currently protected under federal constitutional law by applying international human rights law as a constraint on government power. Since Congress has power to regulate the domestic application of treaties, shifting from a constitutional law discourse to an international human rights discourse would mitigate the tension between judicial review and popular sovereignty by facilitating greater legislative participation in creating rules for the domestic protection of human rights. The next section discusses three examples to illustrate this point.

\section{B. Three Illustrative Examples}

Hamdan v. Rumsfeld ${ }^{314}$ is a rare case where the Court applied the polymorphous model in the twenty-first century. Hamdan involved the trial by military commission of an individual detained at Guantanamo Bay. Defendant challenged the jurisdiction of the military commission, raising a combination of constitutional, common law, statutory, and international law arguments. ${ }^{315}$ The Court could potentially have ruled that the commission procedures violated Hamdan's constitutional rights. ${ }^{316}$ Instead, the Court held that the military commission violated rights protected by the Geneva Conventions and the Uniform Code of Military Justice (UCMJ). ${ }^{317}$ By resolving the case on statutory and treaty grounds, ${ }^{318}$ the Court invited further democratic lawmaking by the political branches. ${ }^{319}$ Hence, the Court mitigated the tension between judicial review and popular sovereignty by ruling against the government without constraining future legislative options. ${ }^{320}$

\footnotetext{
314548 U.S. 557 (2006).

315 See Hamdan v. Rumsfeld, 344 F.Supp.2d 152, 156 (D.D.C. Nov 08, 2004) (summarizing eight counts raised in petition).

${ }^{316}$ Hamdan alleged that the commission procedures violated the Fifth Amendment. See id.

317 See Hamdan, 548 U.S. at 613-35. The Court did not apply the Geneva Conventions directly. Instead, the Court reasoned that the government must comply with the Geneva Conventions because Congress had incorporated the Convention's key substantive provisions into the UCMJ by its statutory reference to the "law of war." See id. at 627-28.

318 Justice Stevens, writing for a plurality, also invoked the "common law of war" in support of his view that the conspiracy charge against Hamdan should be dismissed. See id. at 595-613.

319 See Hamdan, 548 U.S. at 636 (Breyer, J., concurring) ("Nothing prevents the President from returning to Congress to seek the authority he believes necessary. . . . [J]udicial insistence upon that consultation [with Congress] . . . strengthens the Nation's ability to determine-through democratic means-how best to" address the issues.)

320 See Jack Balkin, "Hamdan as a Democracy-Forcing Decision," http://balkin.blogspot.com/2006/06/hamdan-as-democracy-forcing-decision.html (June 29, 2006).
} 


\section{Polymorphous Public Law Litigation}

Judicial supremacists may object that the Court abdicated its responsibility to protect individual rights because Congress subsequently enacted the Military Commissions Act of 2006, ${ }^{321}$ which infringed the due process rights of defendants tried by military commission. ${ }^{322}$ However, that legislation was short-lived. After the 2008 presidential election, President Obama worked with a Democratic Congress to produce the 2009 Military Commissions Act. ${ }^{323}$ Although the 2009 Act does not provide the full range of procedural rights applicable to criminal defendants in federal court, the 2009 Act "addressed a number of key objections to the statutory framework Congress and the Bush Administration had crafted in 2006." 324 Thus, the story of Hamdan and the Military Commissions Act demonstrates that judicial supremacy is not always necessary to protect individual rights. In some cases, the Court can give Congress the last word without sacrificing fundamental rights.

In Miller v. Alabama, ${ }^{325}$ a state court sentenced defendant to life imprisonment without the possibility of parole (LWOP) for a crime he committed at age fourteen. The Alabama statute did not grant the trial judge any discretion to impose a lesser sentence. According to the Supreme Court, that lack of discretion was critical: for juvenile offenders, the Eighth Amendment requires States to accord discretion to trial courts to consider youth as a mitigating factor, and to impose a more lenient sentence in appropriate circumstances. ${ }^{326}$ The Supreme Court reversed the sentence, thereby vindicating defendant's fundamental rights. However, by relying on the Eighth Amendment the Court constrained future legislative options. Thus, Miller illustrates the classic judicial supremacist dilemma. In a system that combines constitutional judicial review with judicial supremacy, either individual rights trump popular sovereignty, or popular sovereignty trumps individual rights. There does not appear to be a middle way.

Assume, hypothetically, that the defendant in Miller challenged the Alabama statute as a violation of his rights under the ICCPR. Article 24(1) specifies that "[e]very child shall have ... the right to such measures of protection as are required by his status as a minor., ${ }^{, 327}$ The Human Rights Committee, a treaty implementing body created by the ICCPR, has said: "sentencing children to [a] life sentence without parole is of itself not in compliance with [A]rticle

\footnotetext{
${ }^{321}$ Military Commissions Act of 2006, Pub. L. No. 109-366, 120 Stat. 2600.

${ }^{322}$ See, e.g., David Kinley, Human Rights Fundamentalisms, 29 SYDNEY L. REV. 545, 556 (2007) (asserting that the 2006 statute provides a "grotesque example of rights and liberties breached in the name of counter-terrorism").

${ }^{323}$ Military Commissions Act of 2009, Pub. L. No. 111-84, div. A, tit. XVIII, 123 Stat. 2574.

${ }^{324}$ Robert M. Chesney, Beyond the Battlefield, Beyond Al Qaeda: The Destabilizing Legal Architecture of Counterterrorism, 112 MicH. L. REV. 163, 176 (2013).

325132 S. Ct. 2455 (2012).

${ }^{326} I d$., at 2463-69.

${ }^{327}$ ICCPR, supra note 299, art. 24(1).
} 


\section{Polymorphous Public Law Litigation}

David Sloss, Draft, January 2014

24(1). ${ }^{328}$ Thus, just as the Supreme Court construed the Eighth Amendment to require state courts to take account of the child's age in sentencing decisions, it could reasonably have construed Article 24 in precisely the same way. Since Article 24 is the "supreme Law of the Land" under the Supremacy Clause, the Court could have reversed the conviction by holding that Article 24 preempted Alabama law. ${ }^{329}$

A treaty preemption holding would be similar to the Court's Eighth Amendment holding because it would vindicate the defendant's rights and constrain future legislative options at the state level. However, by relying on the treaty instead of the Eighth Amendment, the Court would preserve Congress' prerogative to enact legislation authorizing state action inconsistent with the treaty (or inconsistent with the Court's interpretation of the treaty). ${ }^{330}$ Therefore, in contrast to constitutional law discourse, international human rights discourse helps mitigate the tension between judicial review and popular sovereignty.

Next, consider Parents Involved in Community Schools v. Seattle School Dist. ${ }^{331}$ In that case, parents of public school students raised equal protection challenges to affirmative action plans adopted by local school districts in Seattle, Washington, and Louisville, Kentucky. The Court held that both plans violated the Equal Protection Clause because they relied "upon an individual student's race in assigning that student to a particular school."332 The Court's holding is consistent with prior decisions applying strict scrutiny to racial classifications

${ }^{328}$ U.N. Human Rights Comm., Concluding Observations of the Human Rights Committee: United States of America, U.N. Doc. CCPR/C/USA/CO/3/Rev.1 (Dec. 18, 2006).

${ }^{329}$ The main counterargument is that Article 24 is not judicially enforceable because the United States ratified the ICCPR subject to a declaration that the treaty is "not self-executing." The proper interpretation of that declaration is contested. I have argued elsewhere that the declaration should be interpreted to limit the opportunities for plaintiffs to raise treaty claims offensively, but criminal defendants in state courts - like the defendant in Miller - can invoke the treaty defensively. See Sloss, supra note 296. Interpreting the declaration to preclude criminal defendants in state courts from raising a treaty preemption defense would raise serious constitutional problems. See David Sloss, The Constitutional Right to a Treaty Preemption Defense, 40 UNIV. OF TOLEDO L. REV. 971 (2009).

330 Congress has the power under the Necessary and Proper Clause to enact legislation implementing U.S. treaty obligations. Missouri v. Holland, 252 U.S. 416 (1920). In a case currently pending before the Supreme Court, the Court is considering possible federalism limitations on Congress' power to implement treaties under the Necessary and Proper Clause. See Bond v. United States, No. 12-158. Regardless of the Court's decision in Bond, the Court should be hesitant to adopt a constitutional rule prohibiting Congress from enacting legislation to grant States broader discretion to adopt laws that might be inconsistent with U.S. treaty obligations. Such a constitutional rule would be directly at odds with the avowed principles underlying the Court's federalism jurisprudence.

331551 U.S. 701 (2007).

${ }^{332}$ Id . at 710 . 


\section{Polymorphous Public Law Litigation}

intended to benefit disadvantaged groups. ${ }^{333}$ However, that holding is in tension with principles of popular sovereignty and federalism because the Court invalidated policies adopted by local decision-makers who were elected by their local communities to address issues of local concern. ${ }^{334}$ Whether the Court's interference with local, democratic decision-making was necessary to vindicate constitutional rights is debatable. ${ }^{335}$

In contrast to Miller, the Court in Parents Involved could not reasonably have based its holding on international human rights law. Both the ICCPR and CERD prohibit racial discrimination. ${ }^{336}$ However, Article 1(4) of CERD states: "Special measures taken for the sole purpose of securing adequate advancement of certain racial or ethnic groups or individuals . . . shall not be deemed racial discrimination . . . . 337 Moreover, international human rights law generally recognizes the difference between racial classifications intended to harm disfavored minorities (which violate human rights principles), and racial classifications intended to benefit disfavored minorities (which do not violate human rights principles). ${ }^{338}$ Hence, Parents Involved is a case where international human rights law does not provide a substitute for U.S. constitutional law, as currently interpreted by the Supreme Court.

Parents Involved illustrates two key points about the polymorphous model. First, under a polymorphous model the Court would invariably apply constitutional law to decide some cases because international law does not always support the Court's preferred outcome. Second, contrary to the fears raised by international law skeptics, ${ }^{339}$ judicial application of international human rights law is not incompatible with local, decentralized decision-making. To the contrary, affirmative action is an area where international human rights law would permit a large measure of local autonomy, but the Supreme Court - by exercising its

\footnotetext{
${ }^{333}$ See CHEMERINSKY, supra note 306, at 704-09.

${ }^{334}$ In the Seattle case, the contested plan was adopted by the school district's Board of Directors, which is an elected body. See Parents Involved in Community Schools v. Seattle School District No. 1, Brief for Respondents (Oct. 2006). In the Louisville case, the contested plan was adopted by the Jefferson County Board of Education, a body consisting of seven members elected for fouryear terms. See Meredith v. Jefferson County Board of Education, Brief for Respondents (Oct. 2006).

${ }^{335}$ For a persuasive argument that the Court's interference with local decision-making was unwarranted, see Parents Involved, 551 U.S. 701, 803 (Breyer, J., dissenting).

${ }^{336}$ See ICCPR, supra note 299, art. 26; CERD, supra note 307, art. 2.

${ }^{337}$ CERD, supra note 307, art. 1, para. 4.

${ }^{338}$ See, e.g., Ruth Bader Ginsburg \& Deborah Jones Merritt, Affirmative Action: An International Human Rights Dialogue, 21 CARDOZO L. REV. 253 (1999).

${ }^{339}$ See, e.g., Julian G. Ku, The State of New York Does Exist: How the States Control Compliance with International Law, 82 N.C. L. REV. 457, 530-31 (2004) (discussing the alleged conflict between federalism principles and international human rights law).
} 


\section{Polymorphous Public Law Litigation}

constitutional lawmaking power - has mandated a uniform federal rule limiting the policy options available to state and local governments.

\section{Objections to the Polymorphous Model}

This section addresses four key objections to the project of reviving a polymorphous model of public law litigation. The objections relate to federalism, individual rights, national identity and institutional competence.

1. Federalism: Some scholars assert that judicial application of international human rights treaties would undermine federalism. Since human rights treaties address matters traditionally regulated by the States, application of those treaties by federal courts would shift power from the States to the federal government. Hence, the polymorphous model is flawed insofar as it envisions judicial application of international human rights treaties. ${ }^{340}$

This objection is without merit. It is difficult to identify a single right protected under human rights treaties ratified by the United States that is not already regulated at the national level. ${ }^{341}$ Under incorporation doctrine, most rights protected by human rights treaties have already been applied to the States via incorporation into the Fourteenth Amendment. ${ }^{342}$ Other rights have been nationalized by virtue of federal civil rights legislation. ${ }^{343}$ Accordingly, when the United States ratified the ICCPR the federal executive branch told the Senate that federal constitutional and statutory law protected virtually of the rights protected by the treaty. ${ }^{344}$ The executive branch provided similar assurances regarding the CERD and the Torture Convention. ${ }^{345}$ Thus, the federalism objection is unfounded because the United States nationalized human rights law in the latter half of the twentieth century.

\footnotetext{
${ }^{340}$ See id.

${ }^{341}$ The federalism objection may have greater force with respect to unratified treaties - especially CEDAW and the Convention on the Rights of the Child. Here, I address the objection only insofar as it applies to the ICCPR, CERD, and the Torture Convention, the three principal human rights treaties ratified by the United States.

${ }^{342}$ See Duncan v. Louisiana, 391 U.S. 145, 148 (1968) (specifying a long list of rights protected by the Bill of Rights that have been applied to the States via the Fourteenth Amendment).

343 See Heart of Atlanta Motel v. United States, 379 U.S. 241 (1964) (upholding Title II of the 1964 Civil Rights Act and rejecting argument that the statute exceeded the scope of national power).

${ }^{344}$ See Senate Comm. on Foreign Relations, International Covenant on Civil and Political Rights: Report, S. Exec. Rep. No. 102-23, at 10 (1992).

345 See Senate Comm. on Foreign Relations, Report on International Convention on the Elimination of All Forms of Racial Discrimination, S. Exec. Rep. No. 103-29, at 25-26 (1994); Senate Comm. on Foreign Relations, Report on Convention Against Torture and Other Cruel, Inhuman or Degrading Treatment or Punishment, S. Exec. Rep. No. 101-30, at 13-28 (1990).
} 


\section{Polymorphous Public Law Litigation}

David Sloss, Draft, January 2014

Moreover, the Supreme Court has nationalized some rights through aggressive constitutional interpretation that would be left primarily to local decision-makers under international human rights standards. Examples include the Second Amendment right to bear arms, ${ }^{346}$ the First Amendment right to spend money on political campaigns, ${ }^{347}$ and the Fourteenth Amendment right to be free from affirmative action programs. ${ }^{348}$ If implementation of a polymorphous model encouraged the Court to view individual rights issues through an international human rights lens, the Court might reevaluate its jurisprudence in these areas and conclude that nationalization of some or all of these rights is unwarranted. Thus, adoption of a polymorphous model could potentially promote the goals of federalism by fostering greater local autonomy on some issues.

2. Individual Rights: Others may object that the polymorphous model would weaken protection for individual rights. The model encourages courts to decide cases by applying rules that Congress can modify. If courts apply the model, there will invariably be cases in which courts issue decisions protecting individual rights and Congress overrides those decisions, thereby weakening protection for individual rights. ${ }^{349}$

Granted, the possibility of congressional override is an integral feature of the polymorphous model. To understand the model fully, though, one must consider potential judicial responses to override legislation. In Hamdan, as discussed above, Congress overrode the Court's decision by enacting the Military Commissions Acts (MCA). ${ }^{350}$ Currently, criminal defendants in military commission proceedings retain the right to challenge the MCA on federal constitutional grounds. Thus, the Supreme Court still holds a trump card: in a properly presented case, the Court could hold that certain features of the MCA violate defendants' constitutional rights. ${ }^{351}$ Therefore, by applying a polymorphous model and deciding Hamdan on grounds that left open future legislative options, the Court did not relinquish its power to invalidate legislation that violates constitutional rights. The same will be true, generally, in any case where the Court leaves an opening for future legislative deliberation.

\footnotetext{
${ }^{346}$ See supra note 310 and accompanying text.

${ }^{347}$ See supra notes 311-13 and accompanying text.

${ }^{348}$ See supra notes 336-38 and accompanying text.

${ }^{349}$ The Scott Act, passed by Congress in 1888, is one example. The statute was motivated, at least in part, by a desire to reverse the effect of the Supreme Court decision in Chew Heong v. United States, 112 U.S. 536 (1884). See supra notes 231-39 and accompanying text.

${ }^{350}$ See supra notes 321-22 and accompanying text.

${ }^{351}$ For example, the Military Commissions Act of 2009 permits admission into evidence of some statements obtained by coercive methods. See 10 U.S.C. $§ 948$ r(c). The Supreme Court has not ruled on the constitutionality of this provision.
} 


\section{Polymorphous Public Law Litigation}

This observation raises a further objection. Since the Court's power to invalidate federal legislation gives it the ultimate trump card, the ostensible "popular sovereignty" benefits of the polymorphous model are illusory. In the end, the Court is presented with a zero-sum choice between individual rights and popular sovereignty. If the Court invalidates the MCA, individual rights trump popular sovereignty. If the Court upholds the legislation, popular sovereignty trumps individual rights. Realistically, there is no third option. Therefore, the polymorphous model cannot deliver on its promise to reconcile the tension between individual rights and popular sovereignty.

This objection fails to appreciate the benefits of the polymorphous model. By deciding a case on the basis of treaty law, the Court gives both Congress and itself opportunities for further deliberation. Recall the Court's decision in Miller v. Alabama, holding that the Eighth Amendment prohibits States from imposing a mandatory life-without-parole (LWOP) sentence on juvenile offenders. ${ }^{352}$ Under the polymorphous model, the Court could have reached the same result by applying Article 24 of the ICCPR. ${ }^{353}$ In that case, Congress could have held hearings, invited expert testimony, and debated whether to adopt federal legislation authorizing States to impose mandatory LWOP sentences, notwithstanding the Court's interpretation of Article 24. ${ }^{354}$ If Congress decided not to enact such legislation, the outcome would be identical to the result in Miller, but the process generating that outcome would be more consistent with principles of popular sovereignty. If Congress chose to enact legislation overriding the Court's (treaty-based) decision, the Court would retain the power to invalidate that legislation. However, in contrast to the actual case, the Court would have the benefit of recent congressional deliberations to inform its judgment. Thus, the polymorphous model promotes democratic deliberation about the appropriate level of protection for human rights and enriches judicial decisionmaking by providing courts with additional input from legislative hearings and debates.

3. National Identity: Another potential objection to the polymorphous model goes something like this. Our national identity as Americans is inextricably linked to our shared commitment to the Constitution. Judicial review based on constitutional law is a vital expression of our national identity. If U.S. courts routinely applied human rights law as a substitute for constitutional law, we would be forsaking a core element of our national identity. ${ }^{355}$

\footnotetext{
352132 S.Ct. 2455 (2012).

${ }^{353}$ See supra notes 327-28 and accompanying text.

${ }^{354}$ See supra note 330 and accompanying text.

355 Professor Rubenfeld has advanced a similar argument. See Jed Rubenfeld, Unilateralism and Constitutionalism, 79 N.Y.U. L. REV. 1971 (2004).
} 


\section{Polymorphous Public Law Litigation}

One response to this objection involves history. The analysis in Parts Two and Three above demonstrates that federal courts actually applied a polymorphous model for much of our nation's history. Before the Civil War, federal courts applied international law much more frequently than they applied constitutional law to resolve public law controversies. ${ }^{356}$ Clearly, they did not believe that judicial application of international law was "un-American." To the contrary, the Founding generation believed that our nation's commitment to international law was a core element of our national identity. ${ }^{357}$

Granted, in today's world a shift from judicial reliance on constitutional law to greater reliance on international law would involve a change in our selfperception as Americans. However, that change could have very positive repercussions. Many people in other parts of the world view Americans as hypocrites. From their standpoint, we use international human rights rhetoric to criticize other countries for their failings, but we refuse to subject ourselves to the same standards. ${ }^{358}$ A greater judicial willingness to apply international human rights standards to evaluate the conduct of domestic government actors could enhance the U.S. image in the world and help counter the hypocrisy charge.

4. Institutional Competence: The final objection relates to institutional competence. Polling data show that the American public has a very low opinion of Congress. According to recent Gallup polls, "[t]hirteen percent of Americans approve of the job Congress is doing ... Congressional approval has rarely been $20 \%$ or higher in the last three years." ${ }^{, 359}$ In contrast, the American public has a more favorable opinion of the Supreme Court. "Forty-six percent of Americans approve of the way the Supreme Court is handling its job."360

Suppose the public's opinion is well-founded. Suppose, in other words, that judicial lawmaking by the Supreme Court actually promotes the general welfare more effectively than legislative lawmaking by Congress. The polymorphous model is designed to transfer power from the Supreme Court to Congress. If the Court is really a more competent legislator than Congress, then

\footnotetext{
${ }^{356}$ See Figure Three supra.

${ }^{357}$ See David M. Golove and Daniel J. Hulsebosch, A Civilized Nation: The Early American Constitution, The Law of Nations, and the Pursuit of International Recognition, 85 N.Y.U. L. REV. 932 (2010).

358 See, e.g., "Russia: Human Rights Report Criticizes U.S. and Others," N.Y. TIMES, Dec. 29, 2011, at A8 (reporting that Russia's Foreign Ministry "singled out the United States" and attacked as hypocritical the U.S. human rights record).

359 Jeffrey M. Jones, “Congress Job Approval Starts 2014 at 13\%” (Jan. 14, 2014), available at http://www.gallup.com/poll/166838/congress-job-approval-starts-2014.aspx.

360 Andrew Dugan, "Americans Still Divided on Approval of U.S. Supreme Court" (Oct. 4, 2013), available at http://www.gallup.com/poll/165248/americans-still-divided-approval-supremecourt.aspx
} 


\section{Polymorphous Public Law Litigation}

transferring power from the Court to Congress would yield a net loss to public welfare.

Ultimately, the question of comparative institutional competence is an empirical question. Given our nation's deep-rooted commitment to popular sovereignty, those who claim that the Supreme Court has a comparative advantage, and who advocate enhanced judicial power on that basis, must produce very compelling evidence of the Court's superior lawmaking ability to justify vesting greater legislative power in the Supreme Court. At present, the claim that the Supreme Court is a better legislator than Congress remains unproven. Moreover, even if advocates of broad judicial power could prove their case empirically, the appropriate response would be to devise practical methods to improve Congress' performance, rather than abandoning faith in representative democracy.

\section{CONCLUSION}

This article introduces a conceptual distinction between polymorphous public law litigation and constitutionalized public law litigation. The article demonstrates that federal courts applied a polymorphous model of public law litigation in the nineteenth century. Constitutionalization, by contrast, is a more recent development.

The preceding analysis challenges conventional wisdom in four ways. First, conventional wisdom holds that public law litigation is a twentieth century invention. ${ }^{361}$ The article documents the rich tradition of public law litigation in federal courts in the nineteenth century. Second, conventional wisdom holds that application of international law to protect individual rights from government infringement is a modern departure from traditional international law. ${ }^{362}$ The article demonstrates that federal courts in the nineteenth century regularly applied international law to protect individual rights from government infringement.

Third, conventional wisdom holds that protection of individual rights from government infringement requires judicial application of constitutional law. ${ }^{363}$ The article shows that federal courts in the nineteenth century provided robust protection for individual rights without applying constitutional law. Moreover, the article suggests that federal courts in the twenty-first century could protect individual rights from government infringement by applying international human rights law as a partial substitute for federal constitutional law.

\footnotetext{
${ }^{361}$ See, e.g., Chayes, supra note 27.

${ }^{362}$ See, e.g., Milena Sterio, The Evolution of International Law, 31 Bost. Coll InT'L \& COMP. L. REV. 213, 253-55 (2008).

${ }^{363}$ See, e.g., Chemerinsky, supra note 24.
} 


\section{Polymorphous Public Law Litigation}

David Sloss, Draft, January 2014

Fourth, conventional wisdom holds that judicial application of international law is anti-democratic. ${ }^{364}$ In contrast, this article contends that the combination of constitutionalization and judicial supremacy has exacerbated the tension between judicial review and popular sovereignty. U.S. lawyers and judges could mitigate that tension by relying more on international law, and less on constitutional law, to resolve public law controversies. In sum, a twenty-first century revival of the nineteenth century tradition of polymorphous public law litigation - which includes greater judicial reliance on international law - would help move the current, constitutionalized system of public law litigation in a direction that would be more consistent with the democratic commitment to popular sovereignty.

\footnotetext{
${ }^{364}$ See, e.g., McGinnis and Somin, supra note 43.
} 


\section{APPENDIX}

\begin{tabular}{|l|l|l|}
\hline Table One & Based on phase one data & Provides data supporting Figure 1 \\
\hline Table Two & Based on phase two data & Provides data supporting Figures 3, 4, 5 \\
\hline Table Three & Based on phase two data & Provides data supporting Figure 6 \\
\hline Table Four & Based on phase two data & Provides data supporting Figure 7 \\
\hline Table Five & Based on phase two data & Provides data supporting Figures 8 \& 9 \\
\hline
\end{tabular}


Table One

Summary of Data from Phase One Database

Data Supporting Figure 1

\begin{tabular}{|c|c|c|c|c|c|c|c|}
\hline Period & Chief Justices & Years & $\begin{array}{c}\text { Volumes } \\
\text { of US } \\
\text { Reports }\end{array}$ & $\begin{array}{l}\text { Total \# Cases } \\
\text { in Phase One } \\
\text { Database }\end{array}$ & $\begin{array}{c}\text { PG } \\
\text { (Public Law) }\end{array}$ & $\begin{array}{c}\text { PP } \\
\text { (Private Law) }\end{array}$ & Other \\
\hline 1 & Marshall & $1801-1835$ & $5-34$ & 1219 & $\begin{array}{c}32-37 \% \\
(386-449)\end{array}$ & $\begin{array}{c}61-64 \% \\
(742-778)\end{array}$ & $\begin{array}{l}2-5 \% \\
(28-55)\end{array}$ \\
\hline 2 & Taney & 1836-1864 & $35-68$ & 1597 & $\begin{array}{c}25-29 \% \\
(397-467)\end{array}$ & $\begin{array}{c}69-72 \% \\
(1109-1144)\end{array}$ & $\begin{array}{c}1-4 \% \\
(21-56)\end{array}$ \\
\hline 3 & Chase, Waite & $1865-1888$ & $69-126$ & 4537 & $\begin{array}{c}36-38 \% \\
(1657-1726)\end{array}$ & $\begin{array}{c}60-63 \% \\
(2740-2852)\end{array}$ & $\begin{array}{c}1-3 \% \\
(71-115)\end{array}$ \\
\hline 4 & Fuller & $1888-1910$ & $127-218$ & 4918 & $\begin{array}{c}40-44 \% \\
(1960-2178)\end{array}$ & $\begin{array}{c}52-54 \% \\
(2576-2663)\end{array}$ & $\begin{array}{c}3-6 \% \\
(164-316)\end{array}$ \\
\hline 5 & $\begin{array}{l}\text { White, Taft, } \\
\text { Hughes }\end{array}$ & 1910-1936 & 219-298 & 5670 & $\begin{array}{c}49-54 \% \\
(2763-3070)\end{array}$ & $\begin{array}{c}38-40 \% \\
(2158-2281)\end{array}$ & $\begin{array}{c}8-12 \% \\
(442-657)\end{array}$ \\
\hline 6 & $\begin{array}{l}\text { Hughes, Stone, } \\
\text { Vinson }\end{array}$ & 1936-1954 & $299-346$ & 2345 & $\begin{array}{c}60-70 \% \\
(1418-1649)\end{array}$ & $\begin{array}{c}24-25 \% \\
(580-589)\end{array}$ & $\begin{array}{c}5-14 \% \\
(116-338)\end{array}$ \\
\hline 7 & Warren, Burger & 1954-1972 & $347-408$ & 2329 & $\begin{array}{c}68-73 \% \\
(1583-1689)\end{array}$ & $\begin{array}{c}21 \% \\
(487-494)\end{array}$ & $\begin{array}{c}6-11 \% \\
(153-259)\end{array}$ \\
\hline 8 & $\begin{array}{l}\text { Burger, } \\
\text { Rehnquist }\end{array}$ & $1972-2005$ & $409-545$ & 4259 & $\begin{array}{c}65-70 \% \\
(2790-2968)\end{array}$ & $\begin{array}{c}21-22 \% \\
(894-924)\end{array}$ & $\begin{array}{c}9-13 \% \\
(397-545\end{array}$ \\
\hline
\end{tabular}

\section{$\underline{\text { Notes to Table One }}$}

1. In the PG column, the higher numbers (and higher percentages) are based directly on the phase one database. The lower numbers (and lower percentages) are estimates that account for errors identified in phase two. The phase two analysis identified several cases in each time period that were incorrectly classified as PG in phase one.

2. In the PP and "Other" columns, the lower numbers (and lower percentages) are based directly on the phase one database. The higher numbers (and higher percentages) are estimates based on errors identified in phase two. For each time period, the estimates account for the number of PP cases in the phase two database that were incorrectly classified as PG in phase one, and the number of "other" cases in the phase two database that were incorrectly classified as PG in phase one.

3. The phase two analysis did not address periods 4 and 5, so the estimates for periods 4 and 5 are based on average error rates for other time periods. The average error rates used for periods 4 and 5 are as follows:

a. 10 percent of cases classified as $\mathrm{PG}$ in phase one are not PG

b. 4 percent of cases classified as PG in phase one should have been classified as PP

c. 7 percent of cases classified as PG in phase one should have been classified as Other 
Table Two

Data Supporting Figures 3, 4, 5

\begin{tabular}{|l|c|c|c|c|c|c|}
\hline & $\begin{array}{c}\text { Period One } \\
(\mathbf{1 8 0 1 - 1 8 3 5})\end{array}$ & $\begin{array}{c}\text { Period Two } \\
(\mathbf{1 8 3 6 - 1 8 6 4})\end{array}$ & $\begin{array}{c}\text { Period Three } \\
(\mathbf{1 8 6 5 - 1 8 8 8})\end{array}$ & $\begin{array}{c}\text { Period Six } \\
(\mathbf{1 9 3 6 - 1 9 5 4})\end{array}$ & $\begin{array}{c}\text { Period Seven } \\
(\mathbf{1 9 5 4 - 1 9 7 2})\end{array}$ & $\begin{array}{c}\text { Period Eight } \\
(\mathbf{1 9 7 2 - 2 0 0 5})\end{array}$ \\
\hline (1) Private Party & $41.9 \%$ & $41.7 \%$ & $15.6 \%$ & $4.7 \%$ & $.9 \%$ & $3.0 \%$ \\
Raised Int'l Law & {$[34.1,49.7]$} & {$[34.1,49.3]$} & {$[10.3,20.9]$} & {$[1.5,7.9]$} & {$[0,2.2]$} & {$[1.2,4.8]$} \\
Claim & $(\mathrm{N}=155)$ & $(\mathrm{N}=163)$ & $(\mathrm{N}=179)$ & $(\mathrm{N}=169)$ & $(\mathrm{N}=215)$ & $(\mathrm{N}=331)$ \\
\hline (2) Private Party & $8.4 \%$ & $18.4 \%$ & $18.4 \%$ & $50.9(\%)$ & $63.3 \%$ & $73.7 \%$ \\
Raised Con Law & {$[4.0,12.8]$} & {$[12.4,24.4]$} & {$[12.7,24.1]$} & {$[43.3,58.5]$} & {$[56.8,69.8]$} & {$[69.0,78.4]$} \\
Claim & $(\mathrm{N}=155)$ & $(\mathrm{N}=163)$ & $(\mathrm{N}=179)$ & $(\mathrm{N}=169)$ & $(\mathrm{N}=215)$ & $(\mathrm{N}=331)$ \\
\hline (3) Court Below & $44.1 \%$ & $46.9 \%$ & $15.7 \%$ & $3.2 \%$ & $1.0 \%$ & $2.7 \%$ \\
Applied Int'l Law & {$[35.4,52.8]$} & {$[38.7,55.1]$} & {$[10.0,21.4]$} & {$[0.4,6.0]$} & {$[0,2.4]$} & {$[0.8,4.6]$} \\
to Decide Merits & $(\mathrm{N}=127)$ & $(\mathrm{N}=143)$ & $(\mathrm{N}=159)$ & $(\mathrm{N}=157)$ & $(\mathrm{N}=196)$ & $(\mathrm{N}=291)$ \\
\hline (4) Court Below & $6.3 \%$ & $15.4 \%$ & $16.4 \%$ & $49.0 \%$ & $61.7 \%$ & $68.4 \%$ \\
Applied Con Law & {$[2.1,10.5]$} & {$[9.5,21.3]$} & {$[10.6,22.2]$} & {$[41.2,56.8]$} & {$[54.9,68.5]$} & {$[63.0,73.8]$} \\
to Decide Merits & $(\mathrm{N}=127)$ & $(\mathrm{N}=143)$ & $(\mathrm{N}=159)$ & $(\mathrm{N}=157)$ & $(\mathrm{N}=196)$ & $(\mathrm{N}=291)$ \\
\hline (5) Supreme Ct. & $42.5 \%$ & $41.8 \%$ & $15.4 \%$ & $4.1 \%$ & $1.1 \%$ & $3.8 \%$ \\
Applied Int'l Law & {$[34.1,50.9]$} & {$[33.4,50.2]$} & {$[9.7,21.1]$} & {$[0.9,7.3]$} & {$[0,2.6]$} & {$[1.5,6.1]$} \\
to Decide Merits & $(\mathrm{N}=134)$ & $(\mathrm{N}=134)$ & $(\mathrm{N}=156)$ & $(\mathrm{N}=148)$ & $(\mathrm{N}=187)$ & $(\mathrm{N}=264)$ \\
\hline (6) Supreme Ct. & $9.0 \%$ & 16.4 & $21.2 \%$ & $47.3 \%$ & $58.3 \%$ & $68.2 \%$ \\
Applied Con Law & {$[4.1,13.9]$} & {$[10.1,22.7]$} & {$[14.8,27.6]$} & {$[39.2,55.4]$} & {$[51.2,65.4]$} & {$[62.6,73.8]$} \\
to Decide Merits & $(\mathrm{N}=134)$ & $(\mathrm{N}=134)$ & $(\mathrm{N}=156)$ & $(\mathrm{N}=148)$ & $(\mathrm{N}=187)$ & $(\mathrm{N}=264)$ \\
\hline (7) Supreme Ct. & $52.2 \%$ & $45.5 \%$ & $64.1 \%$ & $50.7 \%$ & $41.2 \%$ & $30.3 \%$ \\
Applied Neither & {$[43.7,60.7]$} & {$[37.0,54.0]$} & {$[56.5,71.7]$} & {$[42.6,58.8]$} & {$[34.1,48.3]$} & {$[24.7,35.9]$} \\
Int'l Law nor Con & $(\mathrm{N}=134)$ & $(\mathrm{N}=134)$ & $(\mathrm{N}=156)$ & $(\mathrm{N}=148)$ & $(\mathrm{N}=187)$ & $(\mathrm{N}=264)$ \\
Law & & & & & & \\
\hline
\end{tabular}

\section{Notes to Table Two}

1. For all cells, $\mathrm{N}$ is the number of cases in the sample on which the estimate is based. Numbers in brackets show the $95 \%$ confidence interval for the estimate.

2. For rows 1 and 2, $\mathrm{N}$ is the total number of cases in the phase two database for each period, after eliminating: 1) cases that were not "public law" cases; and 2) cases for which there was insufficient information.

a. For rows 3 and 4, $\mathrm{N}$ is the subset of those cases for each period that yielded a decision on the merits in the court below. The "court below" is the last court that addressed the case before it reached the Supreme Court.

b. For rows 5-7, $\mathrm{N}$ is the subset of those cases for each period that yielded a decision on the merits in the Supreme Court. 
Table Three

Data Supporting Figure 6

Claims Against Federal Government Actors

\begin{tabular}{|l|c|c|c|c|c|c|}
\hline & $\begin{array}{c}\text { Period One } \\
(\mathbf{1 8 0 1 - 1 8 3 5})\end{array}$ & $\begin{array}{c}\text { Period Two } \\
\mathbf{( 1 8 3 6 - 1 8 6 4 )}\end{array}$ & $\begin{array}{c}\text { Period Three } \\
(\mathbf{1 8 6 5 - 1 8 8 8})\end{array}$ & $\begin{array}{c}\text { Period Six } \\
(\mathbf{1 9 3 6 - 1 9 5 4})\end{array}$ & $\begin{array}{c}\text { Period Seven } \\
(\mathbf{1 9 5 4 - 1 9 7 2})\end{array}$ & $\begin{array}{c}\text { Period Eight } \\
(\mathbf{1 9 7 2 - 2 0 0 5})\end{array}$ \\
\hline (1) Private Party & $43.4 \%$ & $58.0 \%$ & $21.7 \%$ & $4.2 \%$ & $1.7 \%$ & $2.1 \%$ \\
Raised Int'l Law & {$[35.2,51.6]$} & {$[48.8,67.2]$} & {$[14.1,29.3]$} & {$[0.6,7.8]$} & {$[0,4.1]$} & {$[0,4.4]$} \\
Claim & $(\mathrm{N}=143)$ & $(\mathrm{N}=112)$ & $(\mathrm{N}=115)$ & $(\mathrm{N}=120)$ & $(\mathrm{N}=117)$ & $(\mathrm{N}=145)$ \\
\hline (2) Private Party & $4.9 \%$ & $6.2 \%$ & $6.1 \%$ & $34.2(\%)$ & $36.8 \%$ & $59.3 \%$ \\
Raised Con Law & {$[1.4,8.4]$} & {$[1.7,10.7]$} & {$[1.7,10.5]$} & {$[25.7,42.7]$} & {$[28.0,45.6]$} & {$[51.3,67.3]$} \\
Claim & $(\mathrm{N}=143)$ & $(\mathrm{N}=112)$ & $(\mathrm{N}=115)$ & $(\mathrm{N}=120)$ & $(\mathrm{N}=117)$ & $(\mathrm{N}=145)$ \\
\hline (3) Supreme Ct. & $44.4 \%$ & $56.5 \%$ & $21.8 \%$ & $5.9 \%$ & $2.0 \%$ & $2.6 \%$ \\
Applied Int'l Law to & {$[35.6,53.2]$} & {$[46.3,66.7]$} & {$[13.7,29.9]$} & {$[1.3,10.5]$} & {$[0,4.7]$} & {$[0,5.5]$} \\
Decide Merits & $(\mathrm{N}=124)$ & $(\mathrm{N}=92)$ & $(\mathrm{N}=101)$ & $(\mathrm{N}=102)$ & $(\mathrm{N}=104)$ & $(\mathrm{N}=117)$ \\
\hline (4) Supreme Ct. & $5.6 \%$ & $4.3 \%$ & $8.9 \%$ & $28.4 \%$ & $30.8 \%$ & $49.6 \%$ \\
Applied Con Law to & {$[1.5,9.7]$} & {$[0.1,8.5]$} & {$[3.3,14.5]$} & {$[19.6,37.2]$} & {$[21.9,39.7]$} & {$[40.5,58.7]$} \\
Decide Merits & $(\mathrm{N}=124)$ & $(\mathrm{N}=92)$ & $(\mathrm{N}=101)$ & $(\mathrm{N}=102)$ & $(\mathrm{N}=104)$ & $(\mathrm{N}=117)$ \\
\hline (5) Supreme Ct. & $53.2 \%$ & $41.3 \%$ & $69.3 \%$ & $68.6 \%$ & $68.3 \%$ & $49.6 \%$ \\
Applied Neither Int'l & {$[44.4,62.0]$} & {$[31.2,51.4]$} & {$[60.3,78.3]$} & {$[59.6,77.6]$} & {$[59.3,77.3]$} & {$[40.5,58.7]$} \\
Law Nor Con Law & $(\mathrm{N}=124)$ & $(\mathrm{N}=92)$ & $(\mathrm{N}=101)$ & $(\mathrm{N}=102)$ & $(\mathrm{N}=104)$ & $(\mathrm{N}=117)$ \\
\hline
\end{tabular}

Notes to Table Three

1. All cases in Table Three are cases in which the private party alleged unlawful conduct by a federal government actor.

2. For all cells, $\mathbf{N}$ is the number of cases in the sample on which the estimate is based. Numbers in brackets show the $95 \%$ confidence interval for the estimate.

3. For rows 1 and 2, $\mathrm{N}$ is the total number of Fed cases in the phase two database for each period, after eliminating cases that were not "public law" cases, and cases for which there was insufficient information.

4. For rows 3-5, $\mathrm{N}$ is the sub-set of Fed cases for each period that yielded a decision on the merits in the Supreme Court. 
Table Four

Data Supporting Figure 7

Claims Against State and Local Government Actors

\begin{tabular}{|l|c|c|c|c|c|c|}
\hline & $\begin{array}{c}\text { Period One } \\
(\mathbf{1 8 0 1 - 1 8 3 5})\end{array}$ & $\begin{array}{c}\text { Period Two } \\
\mathbf{( 1 8 3 6 - 1 8 6 4 )}\end{array}$ & $\begin{array}{c}\text { Period Three } \\
(\mathbf{1 8 6 5 - 1 8 8 8})\end{array}$ & $\begin{array}{c}\text { Period Six } \\
(\mathbf{1 9 3 6 - 1 9 5 4})\end{array}$ & $\begin{array}{c}\text { Period Seven } \\
(\mathbf{1 9 5 4 - 1 9 7 2})\end{array}$ & $\begin{array}{c}\text { Period Eight } \\
(\mathbf{1 9 7 2 - 2 0 0 5})\end{array}$ \\
\hline (1) Private Party & & $5.9 \%$ & $4.7 \%$ & $6.1 \%$ & 0 & $3.5 \%$ \\
Raised Int'l Law & & {$[0,12.4]$} & {$[0,9.9]$} & {$[0,12.9]$} & {$[0,2.0]$} & {$[0.8,6.2]$} \\
Claim & $(\mathrm{N}=51)$ & $(\mathrm{N}=64)$ & $(\mathrm{N}=49)$ & $(\mathrm{N}=98)$ & $(\mathrm{N}=186)$ \\
\hline (2) Private Party & & $45.1 \%$ & $40.6 \%$ & $91.8 \%$ & $94.9 \%$ & $84.9 \%$ \\
Raised Con Law & & {$[31.3,58.9]$} & {$[28.5,52.7]$} & {$[84.1,99.5]$} & {$[90.5,99.3]$} & {$[79.7,90.1]$} \\
Claim & $(\mathrm{N}=51)$ & $(\mathrm{N}=64)$ & $(\mathrm{N}=49)$ & $(\mathrm{N}=98)$ & $(\mathrm{N}=186)$ \\
\hline (3) Supreme Ct. & & $9.5 \%$ & $3.6 \%$ & 0 & 0 & $4.8 \%$ \\
Applied Int'l Law to & & {$[0.5,18.5]$} & {$[0,8.6]$} & {$[0,4.3]$} & {$[0,2.4]$} & {$[1.3,8.3]$} \\
Decide Merits & $(\mathrm{N}=42)$ & $(\mathrm{N}=55)$ & $(\mathrm{N}=46)$ & $(\mathrm{N}=83)$ & $(\mathrm{N}=147)$ \\
\hline (4) Supreme Ct. & & $42.9 \%$ & $43.6 \%$ & $89.1 \%$ & $92.8 \%$ & $83.0 \%$ \\
Applied Con Law to & & {$[27.8,58.0]$} & {$[30.4,56.8]$} & {$[80.0,98.2]$} & {$[87.2,98.4]$} & {$[76.9,89.1]$} \\
Decide Merits & & $(\mathrm{N}=42)$ & $(\mathrm{N}=55)$ & $(\mathrm{N}=46)$ & $(\mathrm{N}=83)$ & $(\mathrm{N}=147)$ \\
\hline (5) Supreme Ct. & & $54.8 \%$ & $54.5 \%$ & $10.9 \%$ & $7.2 \%$ & $15.0 \%$ \\
Applied Neither Int'l & & {$[39.6,70.0]$} & {$[41.2,67.8]$} & {$[1.8,20.0]$} & {$[1.6,12.8]$} & {$[9.2,20.8]$} \\
Law Nor Con Law & & $(\mathrm{N}=42)$ & $(\mathrm{N}=55)$ & $(\mathrm{N}=46)$ & $(\mathrm{N}=83)$ & $(\mathrm{N}=147)$ \\
\hline
\end{tabular}

Notes to Table Four

1. All cases in Table Four are cases in which the private party alleged unlawful conduct by a state or local government actor.

2. For all cells, $\mathbf{N}$ is the number of cases in the sample on which the estimate is based. Numbers in brackets show the $95 \%$ confidence interval for the estimate.

3. For rows 1 and 2, $\mathrm{N}$ is the total number of state/local cases in the phase two database for each period, after eliminating cases that were not "public law" cases, and cases for which there was insufficient information.

4. For rows 3-5, $\mathrm{N}$ is the sub-set of state/local cases for each period that yielded a decision on the merits in the Supreme Court. 
Table Five

\section{Data Supporting Figures 8 \& 9}

\begin{tabular}{|c|c|c|c|c|c|c|}
\hline & $\begin{array}{l}\text { Period One } \\
(1801-1835)\end{array}$ & $\begin{array}{l}\text { Period Two } \\
(1836-1864)\end{array}$ & $\begin{array}{c}\text { Period Three } \\
\text { (1865-1888) }\end{array}$ & $\begin{array}{c}\text { Period Six } \\
(1936-1954)\end{array}$ & $\begin{array}{c}\text { Period Seven } \\
(1954-1972)\end{array}$ & $\begin{array}{l}\text { Period Eight } \\
(1972-2005)\end{array}$ \\
\hline $\begin{array}{l}\text { (1) Challenge } \\
\text { Legislation } \\
\text { (All Cases) }\end{array}$ & $\begin{array}{c}7.7 \% \\
{[3.5,11.9]} \\
(\mathrm{N}=155)\end{array}$ & $\begin{array}{c}15.3 \% \\
{[9.8,20.8]} \\
(\mathrm{N}=163)\end{array}$ & $\begin{array}{c}17.3 \% \\
{[11.7,22.9]} \\
(\mathrm{N}=179)\end{array}$ & $\begin{array}{c}35.5 \% \\
{[28.3,42.7]} \\
(\mathrm{N}=169)\end{array}$ & $\begin{array}{c}28.4 \% \\
{[22.4,34.4]} \\
(\mathrm{N}=215)\end{array}$ & $\begin{array}{c}34.4 \% \\
{[29.3,39.5]} \\
(\mathrm{N}=331)\end{array}$ \\
\hline $\begin{array}{l}\text { (2) Counter } \\
\text { Majoritarian } \\
\text { Claims (All Cases) }\end{array}$ & $\begin{array}{c}5.8 \% \\
{[2.1,9.5]} \\
(\mathrm{N}=155) \\
\end{array}$ & $\begin{array}{c}12.9 \% \\
{[7.7,18.1]} \\
(\mathrm{N}=163) \\
\end{array}$ & $\begin{array}{c}15.1 \% \\
{[9.8,20.4]} \\
(\mathrm{N}=179) \\
\end{array}$ & $\begin{array}{c}34.3 \% \\
{[27.1,41.5]} \\
(\mathrm{N}=169) \\
\end{array}$ & $\begin{array}{c}28.4 \% \\
{[22.4,34.4]} \\
(\mathrm{N}=215) \\
\end{array}$ & $\begin{array}{c}31.7 \% \\
{[26.7,36.7]} \\
(\mathrm{N}=331) \\
\end{array}$ \\
\hline $\begin{array}{l}\text { (3) Majoritarian } \\
\text { Claims } \\
\text { (All Cases) }\end{array}$ & $\begin{array}{c}89.7 \% \\
{[84.9,94.5]} \\
(\mathrm{N}=155)\end{array}$ & $\begin{array}{c}79.1 \% \\
{[72.8,85.4]} \\
(\mathrm{N}=163)\end{array}$ & $\begin{array}{c}79.3 \% \\
{[73.4,85.2]} \\
(\mathrm{N}=179)\end{array}$ & $\begin{array}{c}47.9 \% \\
{[40.3,55.5]} \\
(\mathrm{N}=169)\end{array}$ & $\begin{array}{c}36.7 \% \\
{[30.2,43.2]} \\
(\mathrm{N}=215)\end{array}$ & $\begin{array}{c}23.6 \% \\
{[19.0,28.2]} \\
(\mathrm{N}=331)\end{array}$ \\
\hline $\begin{array}{l}\text { (4) Challenge } \\
\text { Legislation } \\
\text { (Fed Cases) }\end{array}$ & $\begin{array}{c}2.8 \% \\
{[0.1,5.5]} \\
(\mathrm{N}=143)\end{array}$ & $\begin{array}{c}1.8 \% \\
{[0,4.3]} \\
(\mathrm{N}=112)\end{array}$ & $\begin{array}{c}4.3 \% \\
{[0.6,8.0]} \\
(\mathrm{N}=115)\end{array}$ & $\begin{array}{c}20.0 \% \\
{[12.8,27.2]} \\
(\mathrm{N}=120)\end{array}$ & $\begin{array}{c}14.5 \% \\
{[8.1,20.9]} \\
(\mathrm{N}=117)\end{array}$ & $\begin{array}{c}21.4 \% \\
{[14.7,28.1]} \\
(\mathrm{N}=145)\end{array}$ \\
\hline $\begin{array}{l}\text { (5) Counter } \\
\text { Majoritarian } \\
\text { Claims (Fed Cases) }\end{array}$ & $\begin{array}{c}2.8 \% \\
{[0.1,5.5]} \\
(\mathrm{N}=143)\end{array}$ & $\begin{array}{c}0.9 \% \\
{[0,2.7]} \\
(\mathrm{N}=112) \\
\end{array}$ & $\begin{array}{c}4.3 \% \\
{[0.6,8.0]} \\
(\mathrm{N}=115) \\
\end{array}$ & $\begin{array}{c}19.2 \% \\
{[12.1,26.3]} \\
(\mathrm{N}=120) \\
\end{array}$ & $\begin{array}{c}14.5 \% \\
{[8.1,20.9]} \\
(\mathrm{N}=117) \\
\end{array}$ & $\begin{array}{c}21.4 \% \\
{[14.7,28.1]} \\
(\mathrm{N}=145) \\
\end{array}$ \\
\hline $\begin{array}{l}\text { (6) Majoritarian } \\
\text { Claims } \\
\text { (Fed Cases) }\end{array}$ & $\begin{array}{c}95.1 \% \\
{[91.6,98.6]} \\
(\mathrm{N}=143)\end{array}$ & $\begin{array}{c}92.9 \% \\
{[88.1,97.7]} \\
(\mathrm{N}=112)\end{array}$ & $\begin{array}{c}93.9 \% \\
{[89.5,98.3]} \\
(\mathrm{N}=115)\end{array}$ & $\begin{array}{c}65.0 \% \\
{[56.4,73.6]} \\
(\mathrm{N}=120)\end{array}$ & $\begin{array}{c}63.2 \% \\
{[54.4,72.0]} \\
(\mathrm{N}=117)\end{array}$ & $\begin{array}{c}40.7 \% \\
{[32.7,48.7]} \\
(\mathrm{N}=145)\end{array}$ \\
\hline $\begin{array}{l}\text { (7) Challenge } \\
\text { Legislation } \\
\text { (SL Cases) }\end{array}$ & & $\begin{array}{c}45.1 \% \\
{[31.3,58.9]} \\
(\mathrm{N}=51)\end{array}$ & $\begin{array}{c}40.6 \% \\
{[28.5,52.7]} \\
(\mathrm{N}=64)\end{array}$ & $\begin{array}{c}73.5 \% \\
{[61.0,86.0]} \\
(\mathrm{N}=49)\end{array}$ & $\begin{array}{c}44.9 \% \\
{[35.0,54.8]} \\
(\mathrm{N}=98)\end{array}$ & $\begin{array}{c}44.6 \% \\
{[37.4,51.8]} \\
(\mathrm{N}=186)\end{array}$ \\
\hline $\begin{array}{l}\text { (8) Counter } \\
\text { Majoritarian } \\
\text { Claims (SL Cases) }\end{array}$ & & $\begin{array}{c}39.2 \% \\
{[25.7,52.7]} \\
(\mathrm{N}=51)\end{array}$ & $\begin{array}{c}34.4 \% \\
{[22.7,46.1]} \\
(\mathrm{N}=64)\end{array}$ & $\begin{array}{c}71.4 \% \\
{[58.6,84.2]} \\
(\mathrm{N}=49)\end{array}$ & $\begin{array}{c}44.9 \% \\
{[35.0,54.8]} \\
(\mathrm{N}=98)\end{array}$ & $\begin{array}{c}39.8 \% \\
{[32.7,46.9]} \\
(\mathrm{N}=186)\end{array}$ \\
\hline $\begin{array}{l}\text { (9) Majoritarian } \\
\text { Claims } \\
\text { (SL Cases) }\end{array}$ & & $\begin{array}{c}49.0 \% \\
{[35.1,62.9]} \\
(\mathrm{N}=51)\end{array}$ & $\begin{array}{c}53.1 \% \\
{[40.8,65.4]} \\
(\mathrm{N}=64)\end{array}$ & $\begin{array}{c}6.1 \% \\
{[0,12.9]} \\
(\mathrm{N}=49)\end{array}$ & $\begin{array}{c}5.1 \% \\
{[0.7,9.5]} \\
(\mathrm{N}=98)\end{array}$ & $\begin{array}{c}10.2 \% \\
{[5.8,14.6]} \\
(\mathrm{N}=186)\end{array}$ \\
\hline
\end{tabular}

\section{Notes to Table Five}

1. "Fed Cases" are cases in which the private party alleged unlawful conduct by a federal government actor. "SL Cases" are cases in which the private party alleged unlawful conduct by a state or local government actor.

2. See Part III.E for definitions of "majoritarian claims" and "countermajoritarian claims."

3. For rows 1, 4, and 7, a case counts as "challenge legislation" if a private party challenged the validity of legislation adopted by a federal, state, or local legislature.

4. For all cells, $\mathrm{N}$ is the number of cases in the sample on which the estimate is based. Numbers in brackets show the $95 \%$ confidence interval for the estimate.

5. For rows 1-3, $\mathrm{N}$ is the total number of cases in the phase two database for each period, after eliminating: 1) cases that were not "public law" cases; and 2) cases for which there was insufficient information.

a. For rows 4-6, $\mathrm{N}$ is the subset of those cases that count as "Fed Cases."

b. For rows 7-9, N is the subset of those cases that count as "SL Cases."

6. All data in Table Five is based on private party claims, not judicial decisions. 